[Radiocarbon, Vol. 14, No. 1, 1972, P. 6-110]

\title{
GRONINGEN RADIOCARBON DATES X
}

\author{
J. C. VOGEL* and H. T. WATERBOLK** \\ University of Groningen, Netherlands
}

\section{INTRODUCTION}

This list contains most of the unpublished radiocarbon dates measured between 1961 and 1968. Analyses of the $\mathrm{C}^{14}$ content of groundwater are excluded and a number of geologic dates will be included in a later list. Certain earlier analyses performed by $\mathrm{H}$. de Vries and $\mathrm{H}$. de Waard are included, as well as a few results obtained since W. G. Mook assumed responsibility for the laboratory in 1969, to complete series. Descriptions and comments are mainly based on information supplied by the submitters or contained in the publications cited. However, our own interpretation is often given in the comments. Sections I A to D2, II B1, and B2 were mainly prepared by the first author and the rest by the second.

Because the radiocarbon time-scale is not identical with the calendar (astronomic) time-scale (de Vries, 1959; Suess, 1970), and a calibration curve is still to be verified, we suggest that comparison of radiocarbon dates be conducted in the conventional $\mathrm{C}^{14}$ time-scale (years B.P.) and that chronologies based on $\mathrm{C}^{14}$ be clearly distinguished from calendar chronology.

Ages reported here are calculated using the "conventional" halflife of $\mathrm{C}^{14}$, i.e., 5568, and $\mathrm{NBS}$ oxalic acid as recent standard. The $\mathrm{C}^{13}$ content of samples are given with respect to the PDB standard. Where available, $\mathrm{C}^{13}$ corrections are applied to all dates on terrestrial organic material. No correction is applied to marine carbonates (sea shells) since the isotopic fractionation just compensates for the apparent age of surface ocean water. Freshwater carbonates are also not corrected for isotopic fractionation because the initial $\mathrm{C}^{14}$ content is variable. In general, $1300 \pm 500$ years are to be subtracted from such dates (Münnich and Vogel, 1959).

\section{ACKNOWLEDGMENTS}

Thanks are due to all who assisted in sample measurements, especially H. J. Streurman for his competence, and G. Pijpen and G. van der Molen-Sybolts. Ursula Vogel's assistance in preparing the manuscript is also gratefully acknowledged. W. G. Mook is thanked for the $\mathrm{C}^{13}$ analyses and for making available the results of those dates with GrN numbers $>5680$. M. Bierma and J. C. van Dijk are thanked for their competent typing of the manuscript under inevitable stress.

* Natuurkundig Laboratorium, Westersingel 34, Groningen. Present address: National Physical Research Laboratory, P.O. Box 395, Pretoria, South Africa.

** Biologisch-Archeologisch Instituut, Poststraat 6, Groningen. 
SAMPLE DESGRIPTIONS

I. GEOLOGIC SAMPLES

A. Canada

Missinaiba R. series, Ontario

Along Missinaibi R. in James Bay area, N Ontario, non-glacial peat of early or pre-Wisconsin age is exposed. Samples coll. 1954 by O. L. Hughes.

GrN-1435. Missinaibi peat

Peat from exposure on S bank of Missinaibi R. $\left(50^{\circ} 20^{\prime} \mathrm{N}\right.$ Lat, $82^{\circ} 30^{\prime} \mathrm{W}$ Long), ca. $10 \mathrm{~km}$ upstream from mouth of Soweska R., N Ontario. Deposit under till in silt and clay, $4.5 \mathrm{~m}$ below surface. Pollen analysis indicates cool climate (Terasmae, 1958; Terasmae and Hughes, 1960a). Subm. by V. K. Prest, Geol. Survey of Canada, Ottawa. Comments: portion of sample dated in Washington, W-241: $>37,000$ (Science, 1956, v. 129, p. 445). Compare also Y-269: >29,630 (Science, 1955, v. 122, p. 959). (J. Terasmae): recent geologic studies indicate Missinaibi beds probably interglacial.

GrN-1921. Missinaibi, 11 M (B)

$>42,000$

Plant detritus from thin seam of brownmoss peat in uppermost unit in sec. at Bull's Bay on $\mathrm{N}$ bank of Missinaibi R. $\left(50^{\circ} 09^{\prime} \mathrm{N}\right.$ Lat, $83^{\circ} 12^{\prime}$ W Long), N Ontario. Subm. by J. Terasmae, Dept. Geol. Sciences, Brock Univ., St. Catharines, Ontario. Comment (J.T.): expected to date maximum postglacial extent of Tyrrell sea, but obviously of early or pre-Wisconsin age, probably from Missinaibi beds.

\section{GrN-1713. St. Pierre, extract $>\mathbf{4 7 , 0 0 0}$}

In creek ca. $1.6 \mathrm{~km} \mathrm{SW}$ of St. Pierre-les-Becquets $\left(46^{\circ} 31^{\prime} \mathrm{N}\right.$ Lat, $72^{\circ} 10^{\prime} \mathrm{W}$ Long) on S shore of St. Lawrence R., Quebec; exposed sec. of non-glacial silt, sand, and varved clay, with 4 peat layers, lying between tills. Pollen analysis of peat indicates cool Boreal climate, St. Pierre Interstadial (Terasmae, 1958; Terasmae and Hughes, 1960a); 2nd peat layer from top analyzed. Coll. and subm. 1958 by J. Terasmae. Comment: $\mathrm{C}^{14}$ in sample concentrated by isotopic enrichment by factor $11.36 \pm .31$ prior to measurement. $\mathrm{C}^{14}$ content $0.028 \%$ that of modern carbon; error given includes uncertainty of enrichment factor (Vogel, et al., ms. in preparation).

\section{GrN-1807. Pierreville, extract

On E bank of St. Francis R., $2.4 \mathrm{~km} \mathrm{SE}$ of Pierreville (46 $04^{\prime}$ N Lat, $72^{\circ} 49^{\prime} \mathrm{W}$ Long), Quebec, same interstadial deposits as at St. Pierre, above, exposed between tills. Pollen analysis shows correlation 
with upper part of St. Pierre sec. (Terasmae, 1958). Peat from $0.3 \mathrm{~m}$ layer near top coll. 1958 by J. Terasmae. Comments: $\mathrm{C}^{14}$ concentrated by isotopic enrichment by factor $11.04 \pm .37$ prior to measurement. $\mathrm{C}^{14}$ content $0.025 \%$ modern; error includes uncertainty of enrichment factor. (J.T.): A. Dreimanis also believes St. Pierre beds are early-Wisconsin and do not belong to last interglacial.

\section{Scarborough series, Ontario}

At Scarborough Bluffs $\left(43^{\circ} 42^{\prime} 30^{\prime \prime} \mathrm{N}\right.$ Lat, $79^{\circ} 14^{\prime} 10^{\prime \prime} \mathrm{W}$ Long), Toronto, exposure shows $30 \mathrm{~m}$ clay (Scarborough Formation) above Lake Ontario level $(75 \mathrm{~m}$ alt.) followed by $13 \mathrm{~m}$ cross-bedded sand and 4 tills separated by sand or clay. Wood samples coll. 1959 by de Vries and Karrow and 1961 by Karrow; subm. by P. F. Karrow, Univ. of Waterloo, Waterloo, Ontario.

\section{GrN-2555. Scarborough 1}

Twigs from sand at 30 to $43 \mathrm{~m}$ above lake level and ca. $35 \mathrm{~m}$ below surface; coll. 1959.

\section{GrN-4817. Scarborough 2 (enriched}

$54,340 \pm 500$

Wood from same Scarborough sand coll. 1961. Comment: $\mathrm{C}^{14}$ concentrated by isotopic enrichment by factor $11.31 \pm .26$ prior to measurement. $\mathrm{C}^{14}$ content was $0.116 \%$ that of modern carbon; error includes uncertainty of enrichment factor. See Claireville, below.

\section{GrN-4454. Markham, Ontario \\ $24,600 \pm 190$}

Peat ball from $15 \mathrm{~m}$ depth in thick sand and gravel overlying till, covered by 2 further tills in Markham gravel pit $\left(43^{\circ} 50^{\prime} \mathrm{N}\right.$ Lat, $79^{\circ}$ $21^{\prime}$ W Long), $5 \mathrm{~km} \mathrm{SW}$ of Unionville, Ontario. Sands correlated with sands of Scarborough Beds (see above). Coll. 1960 and subm. by P. F. Karrow. Comment: pretreated with warm dilute acid, cold alkali, and acid. Insoluble fraction practically pure clay with insufficient organic material. Alkali soluble fraction measured so that date only minimum. Date should be maximum for deposition of sand layer. Compare W-194: $>34,000$ (Science, 1955 , v. 121, p. 486) for another peat ball from same site. Date 44,600 erroneously communicated to and pub. by submitter.

\section{GrN-4237. Clairville, Ontario}

$>\mathbf{5 0 , 8 0 0}$

Peaty sand from exposure ca. $9 \mathrm{~m}$ from top and ca. $2 \mathrm{~m}$ above river level, $2.1 \mathrm{~km}$ SE of Clairville $\left(43^{\circ} 44^{\prime} \mathrm{N}\right.$ Lat, $79^{\circ} 37^{\prime} \mathrm{W}$ Long), NW of Toronto, Ontario. Sample from lens in lacustrine clay and clayey till below 2 other tills. Pollen analysis shows deposition during cool period. Clay till correlated with Early Wisconsin Sunnybrook Till at Scarborough by Karrow (see above). Coll. and subm. 1962 by A. Dreimanis, Univ. W Ontario, London, Ontario. Comments: pretreated with acid and cold alkali. Material disturbed by glacial action and perhaps displaced. (A.D.): peaty sand probably derived from Scarborough Formation. 


\section{Port Talbot series, Ontario}

On $\mathrm{N}$ shore of Lake Erie, at Bradtville summer cottages $\left(42^{\circ} 37^{\prime}\right.$ $\mathrm{N}$ Lat, $81^{\circ} 23^{\prime} \mathrm{W}$ Long), Dunwich Twp., $3.2 \mathrm{~km} \mathrm{SW}$ of Port Talbot, Ontario, Port Talbot Interstadial beds exposed below ca. $30 \mathrm{~m}$ of till and lacustrine clay and silt (de Vries and Dreimanis, 1960; Dreimanis and Vogel, 1965; Dreimanis et al., 1966). Pollen analysis shows Port Talbot I and II deposited in cool climate. Samples coll. and subm. by A. Dreimanis. Ages given here for samples measured by de Vries in 1958-59 are recalculated and supersede any other pub. figures. For measurements of other labs on similar material see Dreimanis et al., 1966.

GrN-2570. Port Talbot 1, gyttja

$46,700 \pm 1400$

Gyttja coll. 1959 from sandy silt deposit (Port Talbot II Interstadial) in cliff on shore of lake. Comment: pretreated with acid and alkali.

\section{GrN-2601. Port Talbot 2, gyttja (enriched) 45,650 B.c.}

Same as above, isotopically enriched. Comment: pretreated with acid and alkali. $\mathrm{C}^{14}$ concentrated by isotopic enrichment by factor 8.81 \pm .33 before measurement. $\mathrm{C}^{14}$ content was $0.267 \%$ that of modern carbon; error includes uncertainty of enrichment factor.

GrN-4800. Port Talbot twigs, 14

$43,400 \pm 1300$

Twigs from 10 to $10.5 \mathrm{~m}$ below lake level in boring P.T. 14 at type locality, in top of Port Talbot II Interstadial beds and just below glacio-lacustrine clay and silt. Coll. by augering and subm. 1965. Comment: pretreated with acid and alkali.

GrN-4799. Port Talbot twigs, 12/13

$42,700 \pm 1200$ 40,750 в.c.

Plant remains from 10 to $10.5 \mathrm{~m}$ below lake level in borings P.T. 12 and 13 at type site, top of Port Talbot II Interstadial as GRN-4800. Coll. by augering and subm. 1965. Comment: pretreated with acid and alkali.

GrN-4397. Port Talbot twigs, 1

$33,400 \pm 500$ 31,450 B.c.

Larchwood splinters from 10 to $11.5 \mathrm{~m}$ below lake level in boring P.T. 1, $110 \mathrm{~m}$ SW of type site in Port Talbot Interstadial beds as GrN4800. Coll. by wet drilling 1962; subm. 1963. Comments: pretreated with acid and alkali. (A.D.): since $\mathrm{GrN}-4397,-4799$, and -4800 taken by drilling and augering within 1 to $2 \mathrm{~m}$ distance, this date must be rejected as too young.

GrN-2580. Port Talbot 3, wood

$44,400 \pm 1200$

42,450 в.c.

Wood fragments from Southwold Till overlying Port Talbot beds. Assoc. with fragment of mastodon or mammoth tusk. Comment: other 
dates of same wood: S-46: $>34,000$ (R., 1960, v. 2, p. 74); L-440: $>29,500$ (R., 1959, v. 1, p. 9).

\section{GrN-2619. Port Talbot 4, peat ball}

$45,100 \pm 1000$

Inner portion of peat ball from shore of Lake Erie near above exposure, $8 \mathrm{~km} \mathrm{SW}$ of Port Talbot, washed up in 1958. Pollen content similar to that of Pt. Talbot gyttja, above. Although from below lake level, may still be same age as Port Talbot gyttja, since Port Talbot Interstadial deposits were disturbed by glacial over-riding and original position appears to be below lake level. Wood from another peat ball: GSC-217: 47,700 \pm 1200 (R., 1965, v. 7, p. 26, 29).

General Comment (A.D.): Port Talbot II Interstadial dates, from 42,700 \pm 1200 to $47,600 \pm 400$ B.P., agree with each other (not considering date of probably contaminated GrN-4397 material).

\section{Plum Point series, Ontario}

Exposure on $\mathrm{N}$ shore of Lake Erie at Plum Point $\left(42^{\circ} 36^{\prime} \mathrm{N}\right.$ Lat, $81^{\circ} 24^{\prime}$ E Long), $1.8 \mathrm{~km}$ SW of Port Talbot, above, Dunwich twp., Ontario, shows Catfish Creek till down to lake surface. Test boring on shore revealed $1.5 \mathrm{~m}$ till followed by $18 \mathrm{~m}$ Port Talbot II Interstadial deposits: sand, gravel, sand and clay, on reddish Bradtville Till (Dreimanis et al., 1966). Coll. and subm. by A. Dreimanis.

\section{GrN-4429. Plum Point twigs}

$45,800 \pm 1200$

Twigs and leaves from ca. $10 \mathrm{~m}$ below lake surface just above clay and silt. Coll. and subm. 1963. Comment: pretreated with acid and alkali. Date suggests correlation with Port Talbot II Interstadial.

\section{GrN-2625. Plum Point wood}

$27,470 \pm 130$

Larchwood from Catfish Creek till ca. $1 \mathrm{~m}$ above lake surface in cliff on shore. Coll. and subm. 1958. Comments: pretreated with acid and alkali. (A.D.): other dates of same wood: W-177: 27,500 \pm 1200 (Science, 1955, v. 121, p. 485); L-185 B: 28,200 \pm 1500 (Science, 1957, v. 126, p. 1325). Wood derives probably from Plum Point Interstadial deposits, overridden by Late Wisconsin glacier.

\section{St. Thomas series, Ontario}

Peat ball coll. 1961 by P. F. Karrow in Axford's gravel pit at St. Thomas $\left(42^{\circ} 45^{\prime} \mathrm{N} \mathrm{Lat}, 81^{\circ} 11^{\prime} \mathrm{W}\right.$ Long), Ontario, $15 \mathrm{~km} \mathrm{NE}$ of Port Talbot. Contains pollen indicating cool climate as analyzed by A. A. Berti. Sample from base of $7.5 \mathrm{~m}$ gravel underlain by Port Stanley Till. Subm. 1962 by A. Dreimanis.

\section{GrN-4238. St. Thomas peat}

$34,000 \pm 500$

Inner portion of peat ball. Comment: pretreated with hot dilute acid and cold alkali. 


\section{GrN-4272. St. Thomas peat, bis}

$38,000 \pm 1500$

Same sample as above pretreated more rigorously. Comment: pretreated material of GrN-4238 was again extracted with $2 \%$ hot $\mathrm{NaOH}$ solution. Older date shows GrN-4238 was contaminated and GrN-4272 thus only minimum.

General Comment (A.D.): probably derived by varve or stream erosion from Port Talbot II Interstadial peat bed and redeposited as clasts in Late Wisconsin gravels. Porth Talbot Interstadial peat balls found along present Lake Erie beach and in beach gravels of Lake Arkona (13,000 B.P.), of an Erie Interstadial phase of Lake Erie (ca. 15,000 B.P.), and in Plum Point Interstadial beach sands (ca. 25,000 в.P.) between Plum Point and St. Thomas, Ontario.

\section{GrN-4811. St. Fulgence, Quebec}

$9380 \pm 60$

7430 B.C.

Whole shells at 0.60 to $0.80 \mathrm{~m}$ depth in reworked till exposed in gully at St. Fulgence $\left(48^{\circ} 27^{\prime} \mathrm{N}\right.$ Lat, $70^{\circ} 48^{\prime} \mathrm{W}$ Long) $162 \mathrm{~m}$ alt in Saguenay R. valley, near Chicoutimi, Quebec, representing marine invasion in Lake St. John dist. (Lasalle, 1966). Coll. and subm. 1965 by P. Lasalle, formerly Leiden, Netherlands. Comments: outer layers etched off with dilute acid and inner carbonate dated. (P.L.): age is maximum for marine invasion of Sanguenay R. area. Compare GSC-375: $9340 \pm$ 160 в.P. and GSC-313: $8680 \pm 140$ B.P. (R., 1966, v. 8, p. 102) for shells from same area and $\mathrm{GrN}-1922$, below.

\section{GrN-1922. St. Adelphe Bog, Quebec}

$\mathbf{8 7 2 0} \pm 80$

6770 B.c.

Basal $0.10 \mathrm{~m}$ of peat overlying clay at 2.7 to $2.8 \mathrm{~m}$ depth in St.

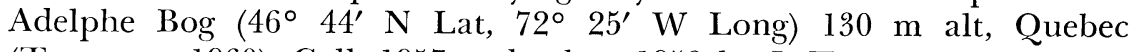
(Terasmae, 1960). Coll. 1957 and subm. 1958 by J. Terasmae. Comment (J.T.): minimum date for beginning of peat accumulation in postChamplain Sea time in St. Lawrence lowlands.

\section{GrN-1924. Alderdale Bog, Ontario}

$6330 \pm 85$

Basal peat from 4.2 to $4.3 \mathrm{~m}$ in Alderdale Bog $\left(46^{\circ} 03^{\prime} \mathrm{N}\right.$ Lat, $79^{\circ} 12^{\prime}$ W Long) in Fossmill Channel, $7 \mathrm{~km}$ SW of Fossmill near North Bay, Ontario. Pollen spectrum shows mixed hardwood phase (Terasmae and Hughes, 1960b). Coll. 1957 and subm. 1958 by J. Terasmae. Comment (J.T.): age assumed minimum for ice retreat from Fossmill, but pollen analysis indicates long time-gap between ice retreat and beginning of peat accumulation.

\section{0 в.c.}

Gyttja at 3.1 to $3.2 \mathrm{~m}$ depth from bottom of High Hill bog on

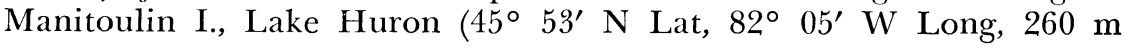


alt), Ontario. Age is minimum for Early Post Lake Algonquin time (Terasmae and Hughes, 1960b). Subm. 1957 by J. Terasmae. Comment (J.T.): indicate early emergence of site from Glacial Lake Algonquin and ice retreat $\mathrm{N}$ of Lake Huron basin.

GrN-1698. Opasatika R., Ontario

$7520 \pm 80$

5570 в.C.

Shells from Opasatika R. ( $50^{\circ} 05^{\prime}$ N Lat, $82^{\circ} 30^{\prime}$ W Long), Ontario, near upper limit of marine submergence after glacial retreat (Terasmae and Hughes, 1960b). Subm. 1958 by J. Terasmae. Comment: shell carbonate dated; may be too young.

GrN-1925. Attawapiskat R., Ontario

$4940 \pm 80$ 2990 B.c.

Basal $2 \mathrm{~cm}$ peat overlying marine clay in riverbank exposure along Attawapiskat R. (53 $08^{\prime}$ N Lat, $85^{\circ} 18^{\prime} \mathrm{W}$ Long), James Bay lowland, Ontario. Coll. 1957 by H. Sjörs; subm. 1958 by J. Terasmae. Comment (J.T.): indicates emergence of area from postglacial Tyrrell sea in James Bay lowlands.

\section{Otto series, New York}

$$
\text { B. U.S.A. }
$$

In Kent Moraine, glacial sediments exposed in $\mathrm{S}$ Branch Cattaraugus Creek (Otto High Bluff) beneath two tills at Otto $\left(42^{\circ} 21^{\prime} \mathrm{N}\right.$ Lat, $78^{\circ}$ $50^{\prime}$ W Long), Cattaraugus Co., New York. Pollen analysis suggests cool to cold climate for organic zone (Muller, 1964). Coll. and subm. 1958 by Hl. de Vries, M. Rubin, and E. H. Muller.

GrN-2632. Otto 1, insoluble $>52,000$

GrN-2565. Otto 1, extract

Organic material from thin sand streak in $9 \mathrm{~m}$ gravel layer, Unit 4. Comment: pretreated with acid and alkali and both insoluble and alkali-soluble fraction measured.

GrN-2634. Otto 2

$63,900 \pm 1700$

GrN-3213. Otto 2 (enriched)

61,950 в.c.

GrN-3163. Otto 2, extract

$>41,000$

Peat from principal peat layer in $2 \mathrm{~m}$ silt layer, Unit 3, below gravel. Comment: pretreated with acid and alkali and $\mathrm{C}^{14}$ concentrated by isotopic enrichment by factor $13.46 \pm 1.18$ prior to measurement. $\mathrm{C}^{14}$ content $0.036 \%$ modern; error includes uncertainty of enrichment factor.

GrN-2633. Otto 3

$>52,000$

Peat from bottom of principal peat layer in Unit 3.

General Comment: although contamination with recent organic material appears slight, $64,000 \mathrm{yr}$ B.P. may be too young. Interstadial beds, Unit 
3, 4, correlate with St. Pierre Interstadial and predate Port Talbot Interstadial (see above).

GrN-5486. Clear Creek, New York

Wood fragments from ca. $13 \mathrm{~m}$ depth in exposure at Clear Creek near Gowanda $\left(42^{\circ} 30^{\prime} \mathrm{N}\right.$ Lat, $78^{\circ} 56^{\prime} \mathrm{W}$ Long), Erie Co., W New York. Coll. 1967 and subm. 1968 by P. E. Calkin, Dept. Geol. Sci., State Univ., Buffalo, New York. Comment: pretreated with acid and alkali. Sample apparently older than Port Talbot Interstadial and possibly equivalent to Otto organic beds (see above).

\section{GrN-4996. Titusville, Pennsylvania}

$40,500 \pm 1000$ 38,550 B.C.

$\delta C^{13}=-28.3 \%$

At Strawbridge's gravel pit, Titusville $\left(41^{\circ} 37^{\prime} \mathrm{N}\right.$ Lat, $79^{\circ} 39^{\prime} \mathrm{W}$ Long), on Crawford-Venango Co. line, Pennsylvania, between margins of Kent Till of Wisconsin age and Titusville Till. Sequence includes till, gravel covering three thin peat layers, interbedded with thin gravel and silt layers and resting on sand. Top peat layer dated $39,900 \begin{aligned} & +4900 \\ & -2900\end{aligned}$ (I-1845, unpub.) and bottom layer $>42,000$ (I-1771, unpub.). This sample from bottom peat layer at ca. $7.5 \mathrm{~m}$ depth. Subm. 1966 by G. W. White, Univ. of Illinois, Urbana, Illinois. Comment: pretreated with acid and alkali. Date not contradictory to I-1771; peat ca. 42,000 yr old or older. See also White and Totten (1965) for date of obviously contaminated sample.

\section{GrN-4398. Etna Township, Ohio}

Wood and twigs in sandy gravel below $53 \mathrm{~m}$ of Late Wisconsin blue-gray till and above blue and hard brown till, washed from $20 \mathrm{~cm}$ drill hole, Dept. Agric. Sta., Etna Township (39 $57^{\prime}$ N Lat, $82^{\circ} 45^{\prime}$ W Long), Licking Co., Ohio. Subm. 1963 by R. P. Goldthwait, Ohio State Univ., Columbus, Ohio. Comment: pretreated with acid and alkali Port Talbot age was expected but antedates Port Talbot Interstadial; possibly St. Pierre Interstadial age (see above). Gravel and lower till considered by earlier workers as Illinoian.

\section{GrN-3219. Rocky Fork, Ohio}

$46,600 \pm 2200$

Wood in top $5 \mathrm{~m}$ gravel outwash on $3 \mathrm{~m}$ till and below $10.5 \mathrm{~m}$ Late Wisconsin till from exposure at Rocky Fork $\left(40^{\circ} 01^{\prime} 06^{\prime \prime} \mathrm{N}\right.$ Lat, $82^{\circ} 5 \mathrm{l}^{\prime}$ 08" W Long), $2 \mathrm{~km} \mathrm{E}$ of Gahanna Village, Jefferson Twp, Franklin Co., Ohio, $10 \mathrm{~km}$ from Etna Township, above (Goldthwait, 1958). Coll. 1961 and subm. by R. P. Goldthwait, Ohio State Univ., Columbus, Ohio. Comment: pretreated with acid and alkali. Same stratigraphic position as Etna Township sample, above. Small $\mathrm{C}^{14}$ content of $0.3 \%$ modern may be due to contamination; date thus only minimum. Whether drift of pre- or Early Wisconsin age, can not be determined by above 2 dates. 


\section{Upper Brush Creek series, Ohio}

In Upper Brush Creek, $0.8 \mathrm{~km} \mathrm{E}$ of Hwy. 25, Shelby Co. (40 $52^{\prime}$ $\mathrm{N}$ Lat, $82^{\circ} 40^{\prime} \mathrm{W}$ Long), Ohio, sequence includes ca. $6 \mathrm{~m}$ till, $0.7 \mathrm{~m}$ clay with fossil soil developed in upper part, $0.5 \mathrm{~m}$ leached sand and gravel, and basal calcareous till. Localized peat lens on top of clay (Goldthwait, 1958). Samples of peat coll. 1958 and subm. by F. Brandtner. In 1963 new samples coll. by J. L. Forsyth, Dept. Nat. Resources, Columbus, Ohio.

\section{GrN-1761. Upper Brush Creek 1a}

$22,430 \pm 140$

Peat from base of lens, ca. $6.5 \mathrm{~m}$ depth, coll. 1958. Comment: pretreated with acid and alkali.

\section{GrN-4512. Upper Brush Creek $1 \mathrm{~b}$}

Another portion of same sample. Comment: new careful pretreatment with acid and alkali.

GrN-4513. Upper Brush Creek 2

$22,400 \pm 260$

Peat from top of lens at ca. $6 \mathrm{~m}$ depth, coll. 1958. Comment: pretreated with acid and cold alkali.

GrN-4133. Upper Brush Creek 3, residue

GrN-4139. Upper Brush Creek 3, extract

New sample (1963) from top of organic rich silt layer, ca. $6.5 \mathrm{~m}$ depth, from different part of exposure. Comment: pretreated with acid and alkali; both insoluble residue and alkali soluble extract measured. Material mainly silt with low organic content.

GrN-4415. Upper Brush Creek 4

$$
\begin{aligned}
& >\mathbf{4 8 , 0 0 0} \\
\delta C^{13} & =-27.1 \% \circ
\end{aligned}
$$

Twigs from organic layer at same position of Sample 3. Comment: pretreated with acid and alkali.

General Comment: previous date for humic silt layer is W-415: $>37,000$ and for $\log$ in lower part of overlying till W-414: 22,000 \pm 1000 (Science, 1958, v. 127, p. 1477). Suspicion that lst date (GrN-1761) could not be correct is refuted by GrN-4512 and GrN-4513. Possible that outwash is older than 48,000 yr (GrN-4415) and that peat developed shortly before Late Wisconsin till was deposited ca. 22,000 yr ago.

\section{GrN-4514. Oxford, Ohio}

$21,340 \pm 125$

19,390 B.c.

$\delta C^{13}=-22.8 \%$

Wood from $\log$ in "basal Wisconsin" till $0.5 \mathrm{~m}$ below "forest bed" underlying Late Wisconsin till in exposure at Oxford $\left(39^{\circ} 30^{\prime} \mathrm{N}\right.$ Lat, $84^{\circ} 45^{\prime}$ W Long), Ohio. Coll. 1958 and subm. by F. Brandtner. Comment: pretreated with acid and alkali. Brandtner considers Oxford forest 
bed same age as Upper Brush Creek peat, above, which is confirmed by dates.

\section{GrN-4614. Grand Rapids, Michigan}

Wood fragments from main peat layer at ca. $12 \mathrm{~m}$ depth at John Ball Park, Grand Rapids ( $42^{\circ} 58^{\prime} \mathrm{N}$ Lat, $85^{\circ} 42^{\prime} \mathrm{W}$ Long), Michigan. Peat overlain by silt, marl, outwash (Valparaiso) and till. Coll. and subm. 1964 by J. H. Zumberge, Grand Valley College, Allendale, Michigan. Comments: pretreated with acid and alkali; (J.H.Z.): pollen shows cool climate, considered post Sangamon. Compare W-1292: >40,000 (R., 1965 , v. 7, p. 376) from same layer.

\section{GrN-4132. Jones Farm, Indiana}

At Jones Farm, $3.2 \mathrm{~km}$ SW of Dublin $\left(39^{\circ} 48^{\prime} \mathrm{N}\right.$ Lat, $85^{\circ} 13^{\prime} \mathrm{W}$ Long), NW Fayette Co., Indiana, sec. in creek exposes $21 \mathrm{~m}$ sequence of till, silt, and sand on Sangamon(?) soil (Gooding, 1963). Wood coll. 1958 by Brandtner and Gooding from lowest till (Whitewater stade) at ca. $0.2 \mathrm{~m}$ above Sangamon and subm. by F. Brandtner. Comment: pretreated with acid and alkali. Other dates from overlying New Paris Interstadial: I-478B: $>40,500$ (unpub.), I-587: >38,000; Fayette Stadial: I-61 1: >40,000; Cornersville Interstadial: I-610: 20,000 \pm 500 (R., 1963, v. 5, p. 65, 66), again suggesting long period of non-deposition or hiatus prior to deposition of Late Wisconsin Till.

\section{GrN-4408. Elburn 62-23, Illinois}

$$
\begin{aligned}
& 32,600 \pm 520 \\
& 30,650 \text { в.c. }
\end{aligned}
$$

Wood from $1.4 \mathrm{~m}$ peat bed at ca. $33 \mathrm{~m}$ depth in Boring NIMAPC 62 (Sample 23), Blackberry Twp $\left(41^{\circ} 52^{\prime} \mathrm{N}\right.$ Lat, $88^{\circ} 25^{\prime} \mathrm{W}$ Long), 11 $\mathrm{km} \mathrm{NW}$ of Aurora, NW Illinois. Peat lies on silt and under $15.5 \mathrm{~m}$ till, $2 \mathrm{~m}$ outwash and $15 \mathrm{~m}$ till, respectively. Subm. 1964 by J. P. Kempton, Ill. State Geol. Survey, Urbana, Illinois. Comment: pretreated with acid and alkali. Considered stratigraphically below Farmdalian, see Farmdale, below. Compare I-1197: >40,000 (unpub.).

\section{GrN-4468. Elgin 14-37A, Illinois \\ $41,100 \pm 1500$}

Peat from ca. $57 \mathrm{~m}$ depth in Boring NIMAPC 14 (Sample 37A), Plato Twp $\left(42^{\circ} 03^{\prime} \mathrm{N}\right.$ Lat, $88^{\circ} 29^{\prime} \mathrm{W}$ Long), ca. $16 \mathrm{~km} \mathrm{~W}$ of Elgin, NW Illinois. Peat lies on silt and below ca. $42.5 \mathrm{~m}$ till, $1 \mathrm{~m}$ outwash, $5 \mathrm{~m}$ till and $7 \mathrm{~m}$ lacustrine silt, respectively. Subm. 1964 by J. P. Kempton. Comment: pretreated with acid and cold alkali. Considered stratigraphically older than Farmdalian, see Farmdale, below. Compare I-848: >40,000 (unpub.).

\section{GrN-1760. Farmdale, Illinois}

$26,700 \pm 180$

24,750 в.c.

Wood from new exposure near type site at Farmdale R.R. Gully, NE of Farmdale, Farm Creek, $10 \mathrm{~km}$ E of Peoria $\left(40^{\circ} 43^{\prime \prime} \mathrm{N}\right.$ Lat, $89^{\circ}$ 38" W Long), Tazewell Co., Illinois, in top of $1 \mathrm{~m}$ peat layer overlain 
by loess and 2 clayey tills (Shelbyville and Post-Shelbyville). Coll. 1958 and subm. by F. Brandtner. Comment: pretreated with acid and alkali. Logs in bottom of lower till, just above loess, date: W-349: 20,340 \pm 750 and $W-399: 20,700 \pm 650$ (Science, 1958, v. 127, p. 1478), indicating Farmdale loess deposited between 26,700 and 20,700 yr ago in accordance with other dates.

\section{GrN-4971. Double Bluff, Washington $\quad>49,400$ \\ $\delta C^{13}=-18.4 \%$}

Wood from Peat Bed $\mathrm{C}$ at ca. $25 \mathrm{~m}$ depth in sea cliff exposure at Double Bluff $\left(47^{\circ} 58^{\prime} \mathrm{N}\right.$ Lat, $112^{\circ} 32^{\prime} \mathrm{W}$ Long), Whidbey I., Washington. Succession shows peat interbedded in sand and silt floodplain deposits (Whidbey Formation) and overlain by till; 2nd peat bed from top dated (Easterbrook, 1969). Coll. and subm. 1965 by D. J. Easterbrook, Dept. Geol., W Wash. State College, Bellingham, Washington. Comment: pretreated with acid and alkali. Whidbey Formation represents warm period older than Possession Drift (see Strawberry Point, below).

\section{Sumner series, Washington}

In E valley wall of Stuck R. (47 $17^{\circ} 13^{\prime} \mathrm{N}$ Lat, $122^{\circ} 13^{\prime} \mathrm{W}$ Long), ca. $1.6 \mathrm{~km} \mathrm{NE}$ of Sumner, S Puget Lowland, Washington, glacial deposits exposed in gully. Salmon Springs drift is overlain by $10 \mathrm{~m}$ Vashon drift and consists of $12 \mathrm{~m}$ sand and gravel, 1 to $1.4 \mathrm{~m}$ nonglacial silt and interbedded peat layer and volcanic ash at base, $7.5 \mathrm{~m}$ sand and gravel (Easterbrook et al., 1967; Crandell et al., 1958). Sample from peat layer coll. 1963 by Dr. R. Mullineaux; subm. by D. R. Crandell, U.S.G.S., Denver, Colorado.
GrN-4074. Sumner, residue
GrN-4094. Sumner, extract
GrN-4116. Sumner, enriched
48,150 в.c.

Peat from below upper part of Salmon Springs drift. Comment: pretreated with acid and alkali. Since both alkali soluble fraction and residue were beyond normal range, $\mathrm{C}^{14}$ concentrated by factor $14.32 \pm$ .43 by isotopic enrichment prior to measurement (GrN-4116). $\mathrm{C}^{14}$ content $0.194 \%$ modern. Error includes uncertainty of enrichment factor. 50,100 B.P. considered minimum for layer. Dates for nonglacial peat between Vashon drift and Salmon Springs drift are 27,900 to 34,700 B.P. (R., 1962, v. 4, p. 4). See also GrN-4971 and GrN-5257, below, and W-672: >38,000 в.P. (R., 1960, v. 2, p. 163) for same peat.

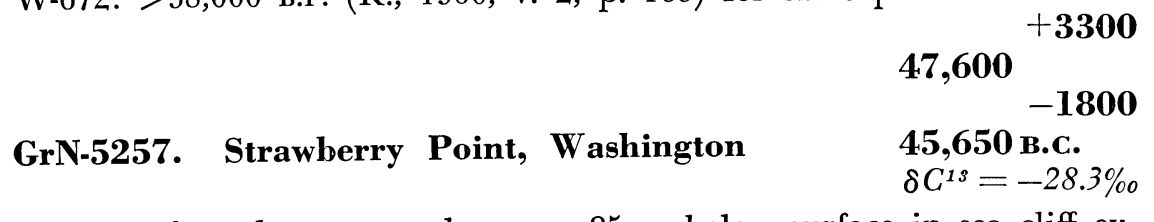

Peat from lowest peat layer ca. $25 \mathrm{~m}$ below surface in sea cliff ex- 
posure at Strawberry Point $\left(48^{\circ} 18^{\prime} \mathrm{N}\right.$ Lat, $122^{\circ} 30^{\prime} \mathrm{W}$ Long) on Whidbey I., Washington. Succession is: Whidbey Formation, Possession Drift with 2 thin peat layers overlain by till and peat (Easterbrook, 1969). Coll. and subm. 1967 by D. J. Easterbrook. Comment: pretreated with acid and alkali. Another date for this peat is: I-2284: >39,900 B.P. Peat layer $1 \mathrm{~m}$ above dates: I-1880: $34,900+3000$ B.P. and upper (interstadial) peat dates: I-1285: $27,200+1000$ B.P. Possession Drift may correspond to upper part of Salmon Springs Drift (see above). See also I-1111: $26,850 \pm 1700$ B.P. (R., 1966, v. 8, p. 171). Cold stade lasted from before 50,000 в.P. to ca. 30,000 в.P.

\section{Gakona series, Alaska}

In Copper R. basin near Gakona (62 $18^{\circ} \mathrm{N}$ Lat, $145^{\circ} 19^{\prime} \mathrm{W}$ Long), Alaska, last glacial is represented by $16.5 \mathrm{~m}$ of sediment overlain by $6 \mathrm{~m}$ postglacial gravel and sand (Ferrians, 1963).

\section{GrN-4165. Gakona \\ GrN-4448. Gakona}

$>46,000$

$>49,000$

$43,440 \pm 250$

\section{GrN-4086. Gakona (enriched)}

41,490 в.c.

Wood from $15 \mathrm{~m}$ below surface in fine sand that grades downward into coarse fluvial gravel and upward into poorly laminated lacustrine clayey silt. Coll. 1962 by H. R. Schmoll; subm. by O. J. Ferrians, U.S.G.S., Washington, D.C. Comment: pretreated thoroughly with acid and alkali. GrN-4165 and GrN-4448 measured without enrichment. For GrN-4086, $\mathrm{C}^{14}$ concentrated by isotopic enrichment by factor $13.17 \pm 0.36$ before measurement. $\mathrm{C}^{14}$ content $0.45 \%$ modern; error includes uncertainty of enrichment factor. Since GrN-4086 younger than unenriched portions, contamination during enrichment was suspected and analysis repeated.

\section{GrN-4744. Gakona, bis}

\section{GrN-4798. Gakona, bis (enriched)}

Another portion of same $\log$ as above. Comment: new portion (ca. $240 \mathrm{~g})$ pretreated with acid and alkali. GrN-4744 measured without enrichment. For GrN-4798, $\mathrm{C}^{14}$ concentrated by isotopic enrichment by factor $10.20 \pm .26$ before measurement. $\mathrm{C}^{14}$ content $0.069 \%$ modern; error includes uncertainty of enrichment factor.

General Comment: 2 enriched samples prove again that contamination took place during handling in lab. where enrichment was undertaken (see also Grossweil 3, R., 1967, v. 9, p. 90). GrN-4798 indicates lower part of glacial beds date back to Early Glacial. Other dates for same horizon is W-531: >38,000 B.P. (R., 1960, v. 2, p. 170), and stratigraphically higher samples in same drift date $31,300 \pm 1000$ B.P. (W-843, R., 
1960 , v. 2, p. 171) and $17,600 \pm 400$ B.P. (W-1134, R., 1964, v. 6, p. 65). Drift thus contemporary with Last Glaciation elsewhere.

GrN-2568. Omar, Delaware $>\mathbf{5 0 , 0 0 0}$

Wood fragments washed from core at $8 \mathrm{~m}$ depth of drilling on sandy silt and clay at Omar ( $38^{\circ} 31^{\prime} \mathrm{N}$ Lat, $75^{\circ} 12^{\prime} \mathrm{W}$ Long), Sussex Co., Delaware. Pollen content shows mainly high percentages of Pinus with Picea and Abies down to $10 \mathrm{~m}$, with Quercus increasing from $10 \mathrm{~m}$ down to $15 \mathrm{~m}$. Coll. 1958; subm. 1959 by J. J. Groot, Delaware Geol. Survey, Newark, Delaware. Comment: compare I-747: >32,000 (R., 1966 , v. 8, p. 173) for similar sample. Date suggests Early Wisconsin or Illinoian, as expected.

\section{Central America}

\section{Lesser Antilles series}

Lower Terrace on islands of Curaçao, Bonaire, and Aruba is youngest of terraces of marine limestone and represents high relative sea level at ca. $+10 \mathrm{~m}$, once thought possibly postglacial. Completeness of shells embedded ensures contemporaneity with deposit. Coll. 1956; subm. 1965 by P. H. de Buisonjé, Dept. Geol., Univ. Amsterdam, Netherlands.

\section{Grn-4435. Curaçao X 1181 A}

$36,500 \pm 800$ 34,550 в.c. $\delta C^{13}=+2.5 \%$

Outer ring of incomplete fossil gastropod (Strombus gigas L.) from surface of Lower Terrace, ca. + $10 \mathrm{~m} \mathrm{E}$ of Boca Tabla (12 22' 15" N Lat, $69^{\circ} 06^{\prime} 48^{\prime \prime}$ W Long), Curaçao.

\section{GrN-4434. Curaçao X 588}

$31,300 \pm 500$ 29,350 в.c. $\delta C^{13}=+2.3 \%$

Outer ring of fossil gastropod (Strombus gigas L.) from base of Lower Terrace, $2.4 \mathrm{~m}$ below top of $10 \mathrm{~m}$ terrace, $\mathrm{W}$ side of Schottegat (12 $07^{\prime} 26^{\prime \prime} \mathrm{N}$ Lat, $68^{\circ} 56^{\prime} 30^{\prime \prime} \mathrm{W}$ Long), Curaçao.

\section{Grn-4436. Aruba, X 1499}

$39,500 \pm 1700$ 37,600 B.C.

$\delta C^{13}=+3.4 \%$

Outer ring of Strombus gigas L. shell from $4.2 \mathrm{~m}$ below top of Lower Terrace, $+5.6 \mathrm{~m}$ at Boca Andicouri (12 $32^{\prime} 26^{\prime \prime} \mathrm{N}$ Lat, $69^{\circ} 57^{\prime}$ $16^{\prime \prime}$ W Long), Aruba.

General Comment: outer portions of samples etched off with dilute acid and inner carbonate dated. Results indicate Lower Terrace not postglacial but since small amouts of recent secondary carbonate would account for $\mathrm{C}^{14}$ content, it is not certain that terrace is interstadial. Dates considered minimum only. Compare also other shell dates 30,000 to 40,000 в.P. for high sea level: GrN-4571: $38,100 \pm 500$ and GrN-4572: $35,000 \pm 630$ (R., 1970, v. 12, p. 450). 
1. Pleistocene of the Netherlands

$$
\text { D. Europe }
$$

GrN-4064. Ommen $X$, Netherlands

Charcoal from boring in continental Eemian deposit, $15 \mathrm{~m}$ below surface in old Vecht $R$. course near Beerze $\left(52^{\circ} 31^{\prime} \mathrm{N}\right.$ Lat, $6^{\circ} 39^{\prime} \mathrm{E}$ Long), $7 \mathrm{~km}$ E of Ommen, prov. Overijssel, Netherlands (Butter, 1957). Coll. 1936 and subm. 1961 by J. Butter, Deventer. Comment: date as expected.

\section{Wageningen series, Netherlands}

In building pit of Phytopathology building in Wageningen $\left(51^{\circ}\right.$ $58^{\prime} \mathrm{N}$ Lat, $5^{\circ} 40^{\prime} \mathrm{E}$ Long), prov. of Gelderland, Netherlands, 2 peat layers at $5.15 \mathrm{~m}$ and $5.25 \mathrm{~m}$ depth below sand separated by cryoturbate sand and gyttja, revealed in 1964. Thought to represent Late or Pleniglacial Interstadial. Samples coll. and subm. 1964 by B. Polak, Landbouwhogeschool, Wageningen, Netherlands.

GrN-4603. Wageninger $5.25 \mathrm{~m}$ $>\mathbf{5 0 , 0 0 0}$

Peat from lower peat layer at $5.25 \mathrm{~m}$ depth.

GrN-4602. Wageningen $5.15 \mathrm{~m}$ $>52,000$

Peat from upper peat layer at $5.15 \mathrm{~m}$ depth.

General Comment: both samples pretreated with acid and alkali. Results indicate peat predates Middle Pleniglacial.

\section{Amersfoort series, Netherlands}

Excavation for building in 1967 (Liendert) in Amersfoort (52 ${ }^{\circ} 09^{\prime}$ N Lat, $05^{\circ} 24^{\prime}$ E Long), prov. of Utrecht, Netherlands, exposed Early Glacial overlain by Pleniglacial beds. Samples coll. by W. H. Zagwijn, Geol. Service, Haarlem, Netherlands, for palynologic and $\mathrm{C}^{14}$ analysis; subm. 1967.

GrN-5405. Amersfoort L II/1

$$
\begin{array}{r}
>\mathbf{5 1 , 2 0 0} \\
\delta C^{13}=-28.1 \% \text { o }
\end{array}
$$

Peat at 6.61 to $6.69 \mathrm{~m}$ depth at top of Early Glacial sequence (Odderade Interstadial ?).

\section{GrN-5404. Amersfoort L I/2}

Peat at 4.70 to $4.75 \mathrm{~m}$ depth in Pleniglacial layer.

$$
\begin{aligned}
& >\mathbf{5 1 , 0 0 0} \\
& \delta C^{13}=-28.4 \% \text { o } \\
& \mathbf{5 1 , 7 0 0} \\
& +3700 \\
& -2400 \\
& \delta C^{13}=-28.4 \%
\end{aligned}
$$

GrN-5375. Amersfoort L I/1

Peat at 4.30 to $4.33 \mathrm{~m}$ depth in Pleniglacial layer.

General Comment: all samples pretreated with acid and cold alkali. First Pleniglacial peat beds older than 50,000 yr recognized in the 
Netherlands. For dates for Early Glacial beds at Amersfoort, see Amersfoort series (R., 1967, v. 9, p. 64-65).

\section{GrN-5480. Nijemegen, Netherlands}

$45,300 \pm 2000$

43,350 в.c.

Cryoturbate sandy peat at De Duckenburg near Nijmegen $\left(51^{\circ} 50^{\prime}\right.$ $\mathrm{N}$ Lat, $5^{\circ} 52^{\prime} \mathrm{E}$ Long), prov. of Gelderland, Netherlands, at 1.80 to $2.00 \mathrm{~m}$ depth below sandy loam and river banks. Pollen diagram points to cold conditions and could be Upper Dryas period if geologic situation did not indicate greater age. Comment: pretreated with acid and alkali. Date suggests Moershoofd Interstadial.

\section{Peelo series, Netherlands}

At bottom of erosion gully filled with fluviatile Pleniglacial deposit at Peelo (53 $01^{\prime} \mathrm{N}$ Lat, $06^{\circ} 34^{\prime} \mathrm{E}$ Long), $\mathrm{N}$ of Assen, prov. of Drente, Netherlands, thin band of moss peat (Amblistegium giganteum) occurs. Pollen analysis shows vegetation similar to that of Moershoofd phase (van der Hammen et al., 1967). Coll. 1966 and subm. 1967 by W. H. Zagwijn.

\section{GrN-5129. Peelo, acid only}

$33,610 \pm 450$

31,660 B.C.

$\delta C^{13}=-33.7 \%$

Peat at ca. $5 \mathrm{~m}$ depth at base of gully. Comment: only pretreated with dilute acid.

GrN-5141. Peelo, residue

\section{GrN-5142. Peelo, extract}

$33,350 \pm 530$

31,400 B.C.

$$
\delta C^{13}=-34.2 \%
$$

$34,050 \pm 500$

32,100 B.C.

$\delta C^{13}=-33.3 \%$

Same material as above. Comment: thoroughly pretreated with boiling $5 \% \mathrm{HCl}$ and cold alkali.

General Comment: similarity of 3 dates indicates no contamination. Result places sample between Hengelo and Denekamp Interstadials, when vegetation was similar to that during Moershoofd phase.

\section{GrN-5460. Smilde, Netherlands}

$18,610 \pm 800$

16,660 B.c.

$\delta C^{13}=-28.2 \%$

Small peat lens at $3.4 \mathrm{~m}$ depth in depression filled with coversand at Hijkersmilde $\left(52^{\circ} 56^{\prime} \mathrm{N}\right.$ Lat, $6^{\circ} 25^{\prime} \mathrm{E}$ Long), $12 \mathrm{~km}$ SE of Assen, prov. of Drenthe, Netherlands. Pollen diagram shows up to $25 \%$ tree pollen, mainly Betula with some Pinus, Picea, and Salix. Similar vegetation during Denekamp Interstadial. Coll. and subm. 1968 by W. A. Casparie, Univ. Groningen, Netherlands. Comment: 1st organic deposit from 28,000 to 14,000 B.P. in Netherlands, suggesting slight climatic improvement. 


\section{de Hamert series, Netherlands}

Two samples from Late Glacial peat bed at de Hamert $\left(51^{\circ} 30^{\prime}\right.$ $\mathrm{N}$ Lat, $6^{\circ} 11^{\prime} \mathrm{E}$ Long), prov. of Limburg, Netherlands. Four dates already pub. (R., 1967, v. 9, p. 76). Coll. 1964-65 and subm. by D. Teunissen, Univ. Nijmegen, Netherlands.

\section{GrN-5216. de Hamert 408}

$$
\begin{gathered}
12,160 \pm 65 \\
10,210 \text { B.C. } \\
\delta C^{13}=-30.5 \%
\end{gathered}
$$

Peat from Boring $5 \mathrm{a}$ at 3.21 to $3.24 \mathrm{~m}$ depth. Just before increase of Betula. Last high herbaceous pollen value. Comment: pretreated with acid and cold alkali.

\section{GrN-5408. de Hamert 404}

$$
\begin{array}{r}
11,465 \pm 50 \\
9515 \text { B.C. } \\
\delta C^{13}=-27.8 \% \circ
\end{array}
$$

Peat from Boring 5a at 3.09 to $3.12 \mathrm{~m}$ depth, just below strong Pinus increase. Betula dominant. Herbaceous pollen low. Comment: pretreated with acid only.

General Comment: from same sec. are dates GrN-4786: 10,870 \pm 100 for top of peat at depth 3.03 to $3.07 \mathrm{~m}$ with Pinus decreasing after its dominance and GrN-4787: 12,210 \pm 90 for basal part of peat at depth 3.27 to $3.30 \mathrm{~m}$ with high value of herbaceous pollen and highest value of Salix in sec. Series very consistent. Comparison with dates from Usselo sec. (Science, 1958, v. 127, p. 130), after applying corrections (R., 1963, v. 5, p. 164), indicates pre-Aller $\phi$ d beginning of peat formation but absence of B $\phi$ lling Interstadial, present in neighboring boring according to date GrN-4478: $12,760 \pm 150$. No clear indication in pollen diagram for colder interval after $\mathrm{B} \phi$ lling period.

\section{GrN-4496. Spoolde, Netherlands}

$$
11,650 \pm 170
$$

9700 B.c.

Gyttja in gully below older and younger coversand layers exposed in sluice-pit at Spoolde (52 $31^{\prime} \mathrm{N}$ Lat, $6^{\circ} 3^{\prime} \mathrm{E}$ Long) near Zwolle, prov. of Overijssel, Netherlands. Depth 4.96 to $5.00 \mathrm{~m}$ below surface. Sample expected to date beginning of lower coversand formation. Expected age: 30,000 to $13,000 \mathrm{yr}$ (Hamming et al., 1965). Coll. and subm. 1963 by G. C. Maarleveld, Univ. Amsterdam, Netherlands. Comment: pretreated with acid and cold alkali. Gyttja unexpectedly Aller $\phi$ d, indicating unobserved stratigraphic complication.

\section{Pleistocene of Other Countries}

\section{GrN-5191. Roxem, Belgium}

$$
\begin{gathered}
11,740 \pm 130 \\
9790 \text { в.c. } \\
\delta C^{13}=-26.1 \% o
\end{gathered}
$$

Wood remains from compressed layer near top of $0.07 \mathrm{~m}$ thick sandy peat exposed in wall of sand pit at depth 2.60 at Roxem-Hoge Dijken near Brugge ( $51^{\circ} 13^{\prime} \mathrm{N}$ Lat, $3^{\circ} 12^{\prime} \mathrm{E}$ Long), prov. of W Flanders, Belgium. Pollen diagram of peat shows Late Glacial flora, with increas- 
ing Betula and low Pinus values. Expected age $\mathrm{B} \phi$ lling. Coll. and subm. 1967 by C. Verbruggen, Seminarie voor Regionale Aardrijkskunde, Univ. Gent, Belgium. Comment: pretreated with acid and alkali. Date indicates Early Aller $\phi$ d age.

\section{Semois valley series, Belgium}

Late Glacial peat from boring, immediately below volcanic ash from Eiffel eruption at depth 2.03 to $2.06 \mathrm{~m}$ in Semois valley between Vance and Chantemelle (49 $46^{\prime} \mathrm{N}$ Lat, $5^{\circ} 40^{\prime} \mathrm{E}$ Long), prov. of Luxemburg, Belgium. Coll. and subm. 1965 by P. D. Jungerius, Fys.-Geog. Lab. Univ. Amsterdam, Netherlands.

\section{GrN-4680. Semois 1}

$$
5400 \pm 90
$$

GrN-4760. Semois 2

General Comment: pretreated with acid and alkali. Both samples from same layer. Material apparently not homogenous, and much too young. Recent roots may have been present.

\section{GrN-4630. Leadenhall St., London, England}

Collagen from ulna of rhinoceros (Coelodonta antiquitatis) from higher flood-plain gravel found 1925 at Lloyd's building site in Leadenhall St., London (57 $30^{\prime} \mathrm{N}$ Lat, $0^{\circ} 10^{\prime} \mathrm{W}$ Long) and subm. 1965 by K. P. Oakley, Brit. Mus. (Nat. Hist.), London. Comment (K.P.O.): date as expected.

\section{GrN-5281. Aber-Mawr, Wales}

Wood fragments from 4 to $5 \mathrm{~m}$ depth in natural coastal exposure at Aber-Mawr (51 ${ }^{\circ} 57^{\prime} 40^{\prime \prime}$ N Lat, $5^{\circ} 05^{\prime} 30^{\prime \prime}$ W Long), St. Nicholas, Fishguard, N Pembrokeshire, Wales. Below ice-contact sand and gravel, ca. $3 \mathrm{~m}$ calcareous Irish Sea Till containing sample lies on solifluction sediments (John, 1965). Coll. and subm. 1967 by B. S. John, Dept. Geog., Sci. Lab., Durham City, England. Comment: indicates Early Würm or older. Compare also other dates for same till NPL-98: >40,300, I-1687: $>36,300$ (R., 1966, v. 8, p. 344; 1968, v. 10, p. 265).

\section{Breinetsried series, Germany}

In gravel quarry Breinetsried $4 \mathrm{~km} \mathrm{~S}$ of Penzberg $\left(47^{\circ} 45^{\prime} \mathrm{N}\right.$ Lat, $11^{\circ} 23^{\prime}$ E Long), in Loisach Valley, Bavaria, $8 \mathrm{~km}$ from Grossweil (see R., 1967, v. 9, p. 89-90), peat layer underlies ca. $6 \mathrm{~m}$ glacial till. Between 2 gravel deposits $0.5 \mathrm{~m}$ Carex-Hypnum peat under- and overlain by 0.3 $\mathrm{m}$ clay contains following approx. pollen spectrum: 10\% Betula (derived?), $18 \%$ Picea, $72 \%$ Pinus plus $110 \%$ Cyperaceae, $12 \%$ Gramineae and is considered Early Glacial Interstadial. Coll. and subm. 1958 by the late H. Gross.

\section{GrN-4998. Breinetsried, residue}




\section{GrN-5011. Breinetsried, extract}

$42,170 \pm 1400$

40,220 B.C.

$\delta C^{13}=-27.0 \%$

Upper $15 \mathrm{~cm}$ of peat layer. Comment: sample pretreated with acid and alkali; both insoluble and alkali soluble fractions measured. Similarity of 2 dates suggests results trustworthy although higher age expected. Compare Signau and Glutschtal series (R., 1967, v. 9, p. 91-92) for other peat layers of this age in Alpine region.

\section{Karrestobel series, Germany}

Previous date for peat from Karrestobel, near Baindt $\left(47^{\circ} 50^{\prime} \mathrm{N}\right.$ Lat, $9^{\circ} 40^{\prime} \mathrm{E}$ Long), Württemberg, $8 \mathrm{~km} \mathrm{~N}$ of Ravensburg (GrN-1277, R., 1967, v. 9, p. 90), provoked much discussion. Additional samples, coll. Sept. 1958 by H. Gross, are reported here. Sequence uncovered in Karrestobel stream bed at 490 to $500 \mathrm{~m}$ alt by A. Bertsch consists of 7 humic layers (A to $G$ ) below 2 to $3.5 \mathrm{~m}$ thick Würm moraine. Uppermost Carex-Hypnum peat, Layer G, $7 \mathrm{~cm}$ thick, covered by 11 to 25 cm slightly layered clay. Subm. 1958 by the late H. Gross.

\section{GrN-4999. Karrestobel G, 1}

Peat from Layer G. Comment: ca. $50 \mathrm{~g}$ compact peat extracted at $80^{\circ} \mathrm{C}$ overnight with $2 \% \mathrm{HCl}$ and $2 \% \mathrm{NaOH}$, respectively; insoluble portion analyzed.

\section{GrN-5071. Karrestobel G, 2, residue}

\section{GrN-5085. Karrestobel G, 2, extract}

Peat from same Layer G. Comment: material boiled with $20 \% \mathrm{HCl}$ and extracted with $4 \%$ cold $\mathrm{NaOH}$; both insoluble and alkali extractable material analyzed.

General Comment: since 2nd pretreatment gave higher date than 1st, it was more effective. Similarity of dates of 2 fractions (GrN-5071 and GrN-5085) indicates reliable result. Previous date, GrN-1277: 29,060 \pm 300, was for sample from Layer E, stratigraphically slightly older than Layer G. Results clearly prove peat of Denekamp Interstadial age.

\section{Piaseczno series, Poland}

Filling of pre-Vistula Valley at Piaseczno sulphur mine near Tarnobrzeg $\left(50^{\circ} 35^{\prime} \mathrm{N}\right.$ Lat, $21^{\circ} 40^{\prime} \mathrm{E}$ Long), woj. Rzeszowskie, SE Poland, consists of cross-bedded gravel overlain by sandy gravel and sand with large black oak trunks in top of sand series. Ice wedges and involutions developed syngenetically with accumulation. Coll. 1965 and subm. 1966 by E. Mycielska-Dowgiallo, Inst. Geog., Univ. Warsaw, Poland. 


\section{GrN-4868. Piaseczno 1}

$40,700 \pm 2000$

38,750 B.c.

$\delta C^{13}=-25.5 \%$

Plant detritus in Layer A at $12.5 \mathrm{~m}$ below present flood terrace. Pollen analysis indicates climate nearing pre-Boreal. Simultaneous occurrence of frost fissures and involutions indicates permafrost (MycielskaDowgiallo, 1967). Comment: pretreated with acid and alkali. Originally, layer ascribed to end of Late Glacial but date implies end of Lower Pleniglacial.

\section{GrN-4867. Piaseczno 2}

$9070 \pm 90$ 7120 B.c.

Peat from layer in middle of trough at ca. $5 \mathrm{~m}$ depth, tentatively ascribed to Atlantic period. Comment: pretreated with acid and alkali. Peat growth apparently started in pre-Boreal time.

\section{GrN-5490. Dzierzby-Krzemien, Poland}

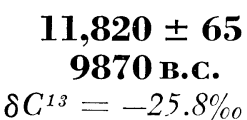

Peaty sand at 1.8 to $2 \mathrm{~m}$ depth below peat, sand, and silt in trial trench at Krzemień-Drohiczyn (52 $30^{\prime} \mathrm{N}$ Lat, $22^{\circ} 30^{\prime} \mathrm{E}$ Long), Sokolów Podlaski prov., Poland, related to Bug R. terraces. Coll. and subm. 1967 by M. J. Dabrowski, Inst. Material Culture Hist., Warsaw, Poland. Comment: pretreated with acid and alkali. Thought possibly Denekamp Interstadial, but date indicates early Aller $\phi$ d age.

\section{GrN-5111. Dobra, Poland}

$32,600 \pm 450$ 30,650 в.P.

$\delta C^{13}=-22.7 \%$

Piece of wood (Pinus cembra) from Dobra $\left(49^{\circ} 45^{\prime} \mathrm{N}\right.$ Lat, $20^{\circ} 20^{\prime}$ E Long) $470 \mathrm{~m}$ alt, near Limanowa on right bank of Lososina R., W Carpathians, Poland. In exposure $10.5 \mathrm{~m}$ clay deposit with angular sandstone scree deposited by solifluction, overlies $1.8 \mathrm{~m}$ gravel, $0.5 \mathrm{~m}$ clay on $0.6 \mathrm{~m}$ gravel (Klimaszewski, 1958). Coll. at ca. $10 \mathrm{~m}$ depth. Pollen spectrum shows $45 \%$ tree pollen, mainly Pinus of which half is Pinus cembra. Subm. 1967 by A. Srodoń, Inst. Bot., Polish Acad. Sci., Kraków, Poland. Comment (A.S.): middle Pleniglacial date for flora acceptable.

\section{GrN-4497. Gorki, Poland}

$$
3300 \pm 35
$$
Gorki (52 $38^{\prime}$ N Lat, $20^{\circ} 35^{\prime} \mathrm{E}$ Long), Puszcza Kampinoska, NE of Warsaw, Poland. Possibly of Aller $\phi$ d age. Coll. 1964 by J. Kobendzina, Warsaw; subm. 1964 by G. C. Maarleveld, Univ. Amsterdam, Netherlands. Comment: pretreated with acid and alkali. Much younger than expected. 
GrN-4491. Kostonjärvi no. 642, Finland

$45,400 \pm 2000$

Peaty sand under $4 \mathrm{~m}$ till and $3 \mathrm{~m}$ gravel at Taivalkoski, Kostonjärvi (65 $45^{\circ} 45^{\prime} \mathrm{N}$ Lat, $28^{\circ} 29^{\prime} \mathrm{E}$ Long), Finland (Korpela, 1969). Coll. and subm. 1964 by K. Korpela, Imatran Voima Oy., Helsinki, Finland. Comment: pretreated with hot dilute acid and cold dilute alkali.

GrN-4543. Permantokoski, Finland

$>42,700$

Peaty sand under ca. $6 \mathrm{~m}$ till at Permantokoski $\left(66^{\circ} 30^{\prime} \mathrm{N}\right.$ Lat, $26^{\circ} 10^{\prime} \mathrm{E}$ Long), Rovaniemi area, Finland. Coll. 1960 and subm. 1964 by K. Korpela. Comment: pretreated with hot dilute acid and cold dilute alkali. With GrN-4491, above, cannot confirm that area was deglaciated between 40,000 and 50,000 B.P., but possibility exists.

\section{GrN-4995. Pulgary 7, Czechoslovakia 24,280 B.c. $\delta C^{13}=-23.2 \%$}

$26,230 \pm 240$

Charcoal from soil (Braunerde) in loess sec. in brickyard at Pulgary, $10 \mathrm{~km} \mathrm{~S}$ of Dolní Vĕstonice (48 $53^{\prime} \mathrm{N}$ Lat, $16^{\circ} 40^{\prime} \mathrm{E}$ Long), S Moravia. Sec. similar to that of Dolní Věstonice (see R., 1967, v. 9, p. 99-101), with lower loam zone and humic bands of early and pre-Würm age, loess, sandy solifluction layer with Braunerde and loess, partly layered. Coll. and subm. 1959 by B. Klima, Brno. Comment: charcoal fragments sieved from soil, fine rootlets removed as far as possible, and pretreated with acid and alkali. Date same as for E Gravettian settlement on top of Síillfried B soil at Pavlov and Dolní Vĕstonice. Probably postdates soil.

\section{Pod hradem series, Czechoslovakia}

Loess samples from Pod hradem (Burghöhle) near Brno $\left(49^{\circ} 12^{\prime} \mathrm{N}\right.$ Lat, $16^{\circ} 40^{\prime} \mathrm{E}$ Long), Moravia, for comparison with charcoal measured previously (R., 1967, v. 9, p. 102). Coll. and subm. 1959 by K. Valoch, Moravské Mus., Brno.

\section{GrN-5543. Pod hradem K, humus}

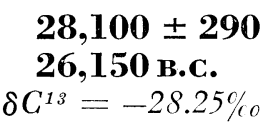

\section{GrN-5567. Pod hradem K, carbonate}

$21,850 \pm 400$ 19,900 B.C.

$\delta C^{13}=-5.2 \%$

Loess from 1.6 to $1.7 \mathrm{~m}$ depth in central passage of cave, in middle of same interstadial as Pod hradem A and $\mathrm{C}$ from side passage. Comment: carbonate removed from loess $(\mathrm{GrN}-5567)$, and humus extracted with $2 \% \mathrm{NaOH}(\mathrm{GrN}-5543)$.

\section{GrN-5542. Pod hradem L, humus}

$30,200 \pm 340$

28,250 в.c.

$\delta C^{13}=-28.3 \%$

Humus extracted from loess at ca. $1.5 \mathrm{~m}$ depth in same layer as Sample K. Comment: carbonate removed and alkali soluble fraction measured. 
General Comment: dates for humus compare satisfactorily with charcoal dates of same layer, GrN-848, -1724, $-1735,-1751$ : 28,200 to 33,300 B.P. (R., 1967, v. 9, p. 102) and indicate contemporaneity of humus in layer. Younger date for carbonate fraction in accordance with experience (see Göttweig-Paudorf series, R., 1967, v. 9, p. 95). Interstadial (previously designated $\mathrm{W}^{1} / 2$ ) of same age as Denekamp Interstadial.

\section{Lunz series, Austria}

Boring of lake sediment in Untersee ca. $2 \mathrm{~km} \mathrm{E}$ of Lunz $\left(47^{\circ} 50^{\prime}\right.$ $\mathrm{N}$ Lat, $15^{\circ} 00^{\prime} \mathrm{E}$ Long), Lower Austria, shows Late and postglacial sequence with 600 to 700 varves between $10.75 \mathrm{~m}$ and $7.70 \mathrm{~m}$, probably formed by retreating Würm glacier. Pollen diagram covers period from Late Glacial to Sub-Atlantic (Burger, 1964). Coll. 1958 by D. Burger; subm. 1961 by Burger and T. van der Hammen.

\section{GrN-4220. Lunzersee $9.70 \mathrm{~m}$}

$35,150 \pm 1250$ 33,200 B.c.

Carbonate from varves at 9.70 to $9.90 \mathrm{~m}$ in top of Zone b correlated with beginning of B $\phi$ lling (1st Pinus maximum). Comment: no pretreatment, carbonate dated. Carbonate apparently derived from old limestone sand. No precipitation of carbonate thus took place in lake in Late Glacial.

\section{GrN-4219. Lunzersee $7.50 \mathrm{~m}$}

$35,850 \pm 700$ 33,900 в.c.

Carbonate from uppermost varves at 7.50 to $7.70 \mathrm{~m}$ in top of Zone d correlated with end of B $\phi 1 l i n g$ (2nd Pinus maximum). Comment: no pretreatment, carbonate dated. Carbonate apparently derived.

GrN-2406. Lunzersee $5.93 \mathrm{~m}$

$10,940 \pm 100$ 8990 B.c.

Peaty calcareous clay from $5.93 \mathrm{~m}$ depth in top of Zone $\mathrm{f}$ with over $90 \%$ Pinus correlated with Aller $\phi$ d and "Lunzer Schwankung" of Gams, partly on basis of this date. Comment: pretreated with acid only. Agrees well with end of Aller $\phi$ d in NW Europe.

\section{GrN-2981. Lunzersee $1.93 \mathrm{~m}$}

$5880 \pm 70$

Peaty calcareous clay from $1.93 \mathrm{~m}$ depth at top of Atlantic period sediment (Zone i) with Picea, Quercetum mixtum, and Corylus pollen predominating. Comment: pretreated with acid only. Agrees well with date ca. 3000 B.c. for beginning of Sub-Boreal in NW Europe.

\section{Ljubljansko Barje series, Yugoslavia}

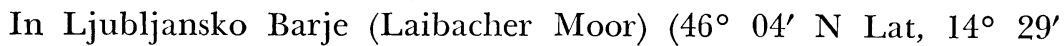
E Long) near Ljubljana, Slovenia, ca. $135 \mathrm{~m}$ pollen-bearing sediment contains evidence of Middle, Upper, and Post Pleistocene vegetation (Šercelj, 1966). Pollen diagram shows Last Glacial divided into initial steppe phase, forest phase (Pinus, Picea, Betula), steppe and Late Glacial forest (Pinus), while Holocene is dominated by mixed forest (Fagus, 
Quercus, etc.). Samples coll. and subm. 1961 by A. Šercelj, Univ. Ljubljana, Yugoslavia.

GrN-4102. Ljubljansko Barje $57 \mathrm{~m}$ $>51,000$

Peat from $57.70 \mathrm{~m}$ depth placed by Šrcelj in Riss-Würm Interglacial. Comment: pretreated with acid and alkali. Date according to expectation.

GrN-4098. Ljubljansko Barje $40 \mathrm{~m}$

Peat from $39.50 \mathrm{~m}$ depth at beginning of main forest phase of Würm Glacial. Comment: pretreated with acid and alkali. Compare Ioannina series, below, where middle of forest phase dates 40,000 B.P.

\section{Adria series, Mediterranean}

Several cores from N Adriatic sea, coll. 1962 by L. van Straaten for micro-malacologic and palynologic studies, contain Glacial and postglacial sediments (Bottema and van Straaten, 1966). In Core 317 at 194 $\mathrm{m}$ below sea level $\left(42^{\circ} 28.3^{\prime} \mathrm{N}\right.$ Lat, $16^{\circ} 26.3^{\prime} \mathrm{E}$ Long) deeper water mollusks decline and shallow water mollusks increase sharply at ca. $4.5 \mathrm{~m}$ depth. At $2.1 \mathrm{~m}$ reverse occurs and at ca. $1.5 \mathrm{~m}$ temperate and later warm pteropods appear. Pollen diagram shows vegetational changes parallel changes in distribution of mollusks. Subm. 1965 by L. van Straaten, Univ. Groningen, Netherlands.

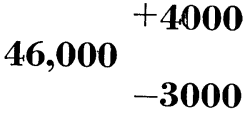

\section{GrN-4712. Adria 4.4 m 44,050 B.C.} shallow shallow water phase. Comment: cleaned carefully, etched with dilute acid and shell carbonate dated. Infinite age not excluded but result considered possible.

\section{GrN-4807. Adria $2.9 \mathrm{~m}$}

$19,870 \pm 220$

Shell fragents from depell fragments from 2.8 to $3.0 \mathrm{~m}$ depth in Core 317 in cold phase deposit. Comment: cleaned carefully and shell carbonate dated.

\section{Tenagi Philippon series, Greece}

The Tenagi Philippon marsh $\left(41^{\circ} 10^{\prime} \mathrm{N}\right.$ Lat, $24^{\circ} 20^{\prime} \mathrm{E}$ Long $)$ in Drama basin, $15 \mathrm{~km}$ W of Kaválla, Macedonia, Greece, contains $120 \mathrm{~m}$ Quaternary sediment of which upper $30 \mathrm{~m}$ represents Last Glacial and Holocene (van der Hammen et al., 1965; Wijmstra, 1969). In 1931 marsh was drained for cultivation. Important pollen diagram of Core II (Wijmstra, 1969) shows 3 Early Glacial interstadials between 28 and $21 \mathrm{~m}$ depth with oak-pine forests followed by long Pleniglacial to ca. $6 \mathrm{~m}$ with open vegetation and periodic Pinus maxima, and Late and postglacial with mainly oak forest and also Fagus and Abies above ca. $2.6 \mathrm{~m}$. First boring in 1960 by Grontmij NV, Netherlands, gave material 
for preliminary pollen diagram (I) and for dating (van der Hammen et al., 1965) while detailed pollen analysis was performed by T. A. Wijmstra on core coll. 1964. Samples of Core I subm. 1963 by W. H. van der Molen, Grontmij NV, de Bilt, Netherlands, and those of Core II subm. 1966 by T. van der Hammen, H. de Vries Lab., Univ. Amsterdam, Netherlands.

GrN-4184. Tenagi Philippon I, $15.80 \mathrm{~m}$ $>\mathbf{4 0 , 0 0 0}$

Peat from $15.80 \mathrm{~m}$ depth in Core I. Interval with more than $20 \%$ Pinus in pollen spectrum. Comment: pretreated with acid and alkali.

GrN-4183. Tenagi Philippon I, $6.25 \mathrm{~m}$

$14,600 \pm 200$

Gyttja from $6.25 \mathrm{~m}$ depth in Core I. Arboreal pollen at a minimum before postglacial increase. Comment: pretreated with acid and alkali.

GrN-4182. Tenagi Philippon I, $4.30 \mathrm{~m}$

$7800 \pm 50$ $\mathbf{5 8 5 0}$ в.c.

Peat from $4.30 \mathrm{~m}$ depth in Core I where Quercus pollen percentage was increasing to last maximum. Comment: pretreated with acid and alkali. Date places level towards end of Boreal phase.

GrN-4849. Tenagi Philippon II, $13.75 \mathrm{~m}$

$\mathbf{3 4 , 7 7 0} \pm \mathbf{5 8 0}$

Gyttja from 13.50 to $14.00 \mathrm{~m}$ depth in Core II. Boundary of Zone P3/P4 in pollen diagram at end of Interstadial (P3) correlated with Hengelo Interstadial.

GRN-4846. Tenagi Philippon II, $11.25 \mathrm{~m}$

$28,840 \pm 300$ 26,890 в.c.

Peat from 11.00 to $11.50 \mathrm{~m}$ depth in Core II. Zone P7 of pollen diagram showing period of amelioration interpreted as end of Denekamp Interstadial.

\section{GrN-4845. Tenagi Philippon II, $9.75 \mathrm{~m}$}

Peat from 9.50 to $10.00 \mathrm{~m}$ depth in Core II. Zone $\mathrm{X} 2$ of pollen diagram with slightly more favorable conditions than immediately before or after.

General Comment: all samples pretreated with acid and alkali. Results from 2 cores show same depth-age relationship from which following dates for Pleniglacial Interstadials can be deduced: ? to ca. 44,000 B.P., 42,000 to 35,000 B.P., 33,000 to 28,500 B.P., 24,500 to 22,000 B.P., and 20,000 to 15,500 B.P. First 3 correspond well with Moershoofd, Hengelo, and Denekamp Interstadials, recognized in the Netherlands (van der Hammen et al., 1967; Vogel and Zagwijn, 1967). Late Glacial boundaries of Wijmstra, however, do not correspond with $\mathrm{C}^{14}$ dates which would place this period between 6.4 and $5.4 \mathrm{~m}$ depth. Age-depth curve gives rise of Quercus and establishment of Tilia at ca. 11,200 B.P.; estab- 
lishment of Ulmus at ca. 10,000 B.P. and Alnus shortly thereafter. A brief maximum $(28 \%)$ of Artemisia at $4.6 \mathrm{~m}$ or 8500 B.P. is considered by Wijmstra to represent Younger Dryas period.

\section{Ioannina series, Greece}

In drained marsh $14 \mathrm{~km} \mathrm{NW}$ of Ioannina $\left(39^{\circ} 46^{\prime} \mathrm{N}\right.$ Lat, $20^{\circ} 44^{\prime}$ E Long), Epirus, Greece, $11.6 \mathrm{~m}$ boring by W. van Zeist and S. Bottema gave pollen diagram covering postglacial and large part of Last Glacial periods (Bottema, 1967). Pollen Zone I (bottom) shows high percentage of herbs, Zone II (11 m to $6.8 \mathrm{~m}$ ) high tree-pollen percentage, Zone III $(6.7 \mathrm{~m}$ to $3 \mathrm{~m}$ ) high percentage of herbs, Zone IV (2.8 $\mathrm{m}$ to top) high tree-pollen percentage. Zone II reflects warmer and moister climate than Zone I and III although high percentage of Fagus suggests it was cooler than present (Zone IV). Samples subm. 1966 by W. van Zeist and S. Bottema, Univ. Groningen, Netherlands.

\section{GrN-4793. Ioannina $7.90 \mathrm{~m}$}

$$
40,000 \pm 1000
$$

\section{Thin peat layer at $7.80 \mathrm{~m}$, $\mathbf{3 8 , 0 5 0}$ B.c.}

(high Pinus). Commen in top of Zone IIb (high Pinus). Comment: pretreated with acid and alkali. Sub-zone IIb preceded and followed by oak maxima. Comparison with pollen diagram of Tenagi Philippon (see above) suggests Zone II corresponds to end of Early Glacial and Lower Pleniglacial, though date places it slightly higher in sequence. Pleniglacial, though in region seems to change from cool and moist to cold and dry.

\section{GrN-4875. Ioannina $2.67 \mathrm{~m}$}

$$
\begin{gathered}
10,200 \pm 90 \\
\mathbf{8 2 5 0} \text { B.c. } \\
\delta C^{13}=-26.2 \% o
\end{gathered}
$$

Peaty clay at $2.65 \mathrm{~m}$ to $2.69 \mathrm{~m}$ depth at bottom of Zone IV. Comment: pretreated with acid only. Oak already predominant. Date corresponds to Late Glacial/postglacial boundary in NW Europe.

\section{Padul series, Spain}

In peat bog SE of Padul ( $37^{\circ} 02^{\prime} \mathrm{N}$ Lat, $3^{\circ} 37^{\prime} \mathrm{W}$ Long), prov. of Granada, Spain, $>50 \mathrm{~m}$ pollen-bearing peat and clay represent considerable part of Pleistocene. Four cores, II, IV, V, and VI, coll. for pollen analysis in 1958-1960 and 1965, respectively. Preliminary pollen diagram of Core IV (Menéndez Amor and Florschütz, 1962, 1964) interpreted to show Last Glacial between ca. $17 \mathrm{~m}$ and $3.5 \mathrm{~m}$ with Pinus dominance and $<5 \%$ Quercetum mixtum between $12.0 \mathrm{~m}$ and $5.3 \mathrm{~m}$. Above $5.1 \mathrm{~m}$ Quercetum mixtum increases to $>40 \%$ and Pinus decreases to ca. $15 \%$, with a relapse between $4.4 \mathrm{~m}$ and $4.1 \mathrm{~m}$. Between $12.7 \mathrm{~m}$ and $24 \mathrm{~m}$ up to $40 \%$ Quercetum mixtum occurs, but Pinus is mostly dominant. $10 \mathrm{~cm}$ portions of cores subm. by the late F. Florschütz.

\section{GrN-850. Padul II 3}

Peat from $7.90 \mathrm{~m}$ depth in Core II. 
GrN-1950. Padul II 2

Peat from $3.90 \mathrm{~m}$ depth in Core II.

GrN-1949. Padul II 1

Peat from $1.40 \mathrm{~m}$ depth in Core II.

General Comment: dates of Core II incorporated in pollen diagram of Core IV in Menéndez Amor and Florschütz (1964).

GrN-2630. Padul IV 10

$>54,000$

Peat from $11.37 \mathrm{~m}$ depth in Core IV.

GrN-2657. Padul IV 9

$>51,000$

Peat from $10.87 \mathrm{~m}$ depth in Core IV.

GrN-2147. Padul IV 8

Peat from $10.37 \mathrm{~m}$ depth in Core IV.

GrN-2658. Padul IV 7

Peat from $9.37 \mathrm{~m}$ depth in Core IV.

GrN-2146. Padul IV 6

Peat from $8.37 \mathrm{~m}$ depth in Core IV.

GrN-2145. Padul IV 5

Peat from $7.37 \mathrm{~m}$ depth in Core IV.

GrN-2955. Padul V 2

Peat from $6.90 \mathrm{~m}$ depth in Core V.

GrN-2327. Padul IV 4

Peat from $5.87 \mathrm{~m}$ depth in Core IV.

GrN-2952. Padul V 1

Peat from $4.40 \mathrm{~m}$ depth in Core V.

GrN-2191. Padul IV 3

Peat from $3.87 \mathrm{~m}$ depth in Core IV. Stratigraphically same as GrN-1950, above.

GrN-2187. Padul IV 2

Peat from $1.87 \mathrm{~m}$ depth in Core IV.

GrN-2185. Padul IV 1

Peat from $0.11 \mathrm{~m}$ depth in Core IV.
$46,440 \pm 2000$

44,490 в.C.

$43,220 \pm 900$ 41,270 в.c.

$38,540 \pm 1300$ 36,590 в.c.

$34,370 \pm 900$

32,420 в.c.

$30,270 \pm 450$ 28,320 B.C.

$17,000 \pm 145$ 15,050 B.C.

$13,000 \pm 100$

11,050 в.C.

$10,110 \pm 85$ 8160 в.C.
$6750 \pm 90$

4800 в.C.

$4980 \pm 60$

3030 B.C.
$10,470 \pm 120$

8520 B.C.

$6360 \pm 85$

4410 в.C. 
General Comment: all samples pretreated with acid only. By interpolation, Quercetum mixtum forest increases from a few per cent to $37 \%$ at ca. 15,000 B.P. and is below 5\% between 13,000 and 11,000 B.P. when Pinus is dominant. After 11,000 B.P., Quercetum mixtum gains permanent dominance. Wide spacing of pollen samples may have caused fine structure between 13,000 and 11,000 B.P. to have been missed.

\section{GrN-4808. Padul VI 1 b}

Peat from 12.50 to $12.55 \mathrm{~m}$ depth in Core VI. Comment: pretreated with acid and cold alkali. On basis of pollen diagram of Core IV, this and GrN-4805, below, expected to date disappearance of Quercetum mixtum forest in Early Glacial.

\section{GrN-4805. Padul VI I}

$39,150 \pm 920$ 37,200 в.c.

Peat from 12.35 to $12.45 \mathrm{~m}$ depth in Core VI. Comment: pretreated with acid and alkali. Compared with GrN-4956, GrN-5026, and GrN2630, this sample too young.

\section{GrN-4943. Padul VI 2, residue}

\section{GrN-4956. Padul VI 2, extract}

\section{GrN-5026. Padul VI 2, extract (enriched)} Peat from 11.87 to $12.32 \mathrm{~m}$ depth in Core VI. Comment: pretreated organic matt and cold alkali, both fractions dated. Since most of the $100 \mathrm{~g}$ of extract combusted for isotopic this fraction gave higher age, $100 \mathrm{~g}$ of extract combusted for isotopic enrichment and enriched by factor $8.00 \pm .05$ before measurement. Residue appears too young, compared with extract, and all dates at this depth are too young if depths in Core VI are stratigraphically same as in Core IV. Until pollen diagram of Core VI is available, no explanation for discrepancy is possible.

\section{Holocene of the Netherlands}

\section{Bourtanger Moor series, Netherlands}

Peat bog development in remains of former large raised bog "Bourtanger Moor", $\mathrm{E}$ of Emmen (52 $48^{\prime} \mathrm{N}$ Lat, $7^{\circ} 0^{\prime} \mathrm{E}$ Long), prov. of Drenthe, Netherlands, was studied by W. A. Casparie (in press). Series consists of 23 dates on Pinus stumps from 5 localities (A-E) and levels in bog, which could be grouped dendro-chronologically by A. V. Munaut into several floating tree-ring sequences, the 2 longest (groups $\mathrm{D}^{\circ}$ and $\mathrm{DEE}^{\circ}$ ) comprising 330 and 369 yr. Dates were used by Vogel, Casparie, and Munaut (1969) for studying trends in $\mathrm{C}^{14}$ content of atmosphere before 6000 B.P. See also Munaut and Casparie (in press). Sample coll. by W. A. Casparie, Biol.-Archeol. Inst., Univ. Groningen, Netherlands, and A. V. Munaut, Lab. Palynol. et Phytosociol., Heverlee-Louvain, Belgium. 


\section{GrN-4267. Emmen $D^{\circ} 1-6$}

Tree rings 234 to 244 from Stump $D^{\circ} 1$.

GrN-4266. Emmen $D^{\circ}$ 1-5

Tree rings 184 to 194 from Stump $\mathrm{D}^{\circ} 1$.

GrN-4265. Emmen $D^{\circ}$ 1-4

Tree rings 134 to 144 from Stump $D^{\circ} 1$.

GrN-4264. Emmen $D^{\circ} 1-3$

Tree rings 84 to 94 from Stump $\mathrm{D}^{\circ} 1$.

GrN-4263. Emmen $D^{\circ}$ 1-1

Tree rings 29 to 39 from Stump $D^{\circ} 1$.

GrN-4276. Emmen $E^{\circ} \quad$ 1-4

Tree rings 207 to 217 from Stump E ${ }^{\circ} 1$.

GrN-4278. Emmen $E^{\circ} \quad 1-3$

Tree rings 157 to 167 from Stump $E^{\circ} 1$.

GrN-4277. Emmen $E^{\circ} \quad 1-2$

Tree rings 107 to 117 from Stump $E^{\circ} 1$.

GrN-4279. Emmen $E^{\circ} \quad 1-1$

Tree rings 57 to 67 from Stump $\mathrm{E}^{\circ} 1$.

GrN-4303. Emmen E 4-4

Tree rings 172 to 182 from Stump E 4 .

GrN-4302. Emmen E 4-3

Tree rings 122 to 132 from Stump E 4 .

$$
\begin{aligned}
& 6910 \pm 30 \\
& 4960 \text { B.C. } \\
& \delta C^{13}=-25.2 \% \\
& 7005 \pm 35 \\
& 5055 \text { B.C. } \\
& \delta C^{13}=-24.2 \% \text { o } \\
& 7025 \pm 30 \\
& 5075 \text { B.c. } \\
& \delta C^{13}=-24.6 \% \\
& 7170 \pm 30 \\
& 5220 \text { в.c. } \\
& \delta C^{13}=-26.3 \% \\
& 7130 \pm 30 \\
& 5180 \text { B.c. } \\
& \delta C^{13}=-26.4 \% \text { o } \\
& 6150 \pm 30 \\
& 4200 \text { B.c. } \\
& \delta C^{13}=-25.3 \% \\
& 6225 \pm 32 \\
& 4275 \text { в.c. } \\
& \delta C^{13}=-24.8 \% \text { o } \\
& 6230 \pm 33 \\
& 4280 \text { B.C. } \\
& \delta C^{13}=-24.8 \% \text { o } \\
& 6290 \pm 32 \\
& 4340 \text { B.c. } \\
& \delta C^{13}=-24.9 \% \\
& 6075 \pm 63 \\
& 4125 \text { B.C. } \\
& \delta C^{13}=-24.3 \% \\
& 6220 \pm 63 \\
& 4270 \text { B.C. } \\
& \delta C^{13}=-24.2 \% o
\end{aligned}
$$


GrN-4301. Emmen E 4-1

Tree rings 22 to 32 from Stump E 4. 4250 B.C.

$\delta C^{13}=-27.3 \%$

\section{GrN-4314. Emmen D 2-1}

$6170 \pm 64$

Tree rings 115 to 123 from Stump D 2 .

\section{GrN-4918. Emmen $E^{\circ}$ 4-6}

Tree rings 180 to 190 from Stump E ${ }^{\circ} 4$.

\section{GrN-4917. Emmen $E^{\circ}$ 4-5}

Tree rings 150 to 160 from Stump E ${ }^{\circ} 4$.

GrN-4916. Emmen $E^{\circ} \quad$ 4-4

Tree rings 120 to 129 from Stump E ${ }^{\circ} 4$.

\section{GrN-4915. Emmen $E^{\circ}$ 4-3}

Tree rings 90 to 100 from Stump $\mathrm{E}^{\circ} 4$.

\section{GrN-4914. Emmen $E^{\circ}$ 4-2}

Tree rings 61 to 68 from Stump E $\mathrm{E}^{\circ} 4$.

\section{GrN-4913. Emmen $E^{\circ}$ 4-1}

Tree rings 31 to 39 from Stump $\mathrm{E}^{\circ} 4$.

\section{GrN-4275. Emmen B 2-5}

Tree rings 100 to 109 from Stump B 2.

\section{GrN-4274. Emmen B 2-1}

Tree rings 1 to 10 from Stump B 2 .

GrN-4313. Emmen C 4-1

Tree rings 74 to 89 from Stump C 4 .

4220 B.C.

$\delta C^{13}=-24.6 \%$

$6160 \pm 30$

4210 B.C.

$\delta C^{13}=-24.8 \%$ o

$6365 \pm 30$

4415 B.c.

$\delta C^{13}=-24.7 \%$ o

$6310 \pm 32$

4360 B.C.

$\delta C^{13}=-25.0 \%$ o

$6410 \pm 32$

4460 в.c.

$\delta C^{1 s}=-25.2 \%$ 。

$$
6440 \pm 30
$$

4490 B.C.

$\delta C^{13}=-24.7 \%$

$6325 \pm 32$

4375 B.C.

$\delta C^{13}=-25.8 \%$

$5890 \pm 65$

3940 B.C.

$\delta C^{13}=-26.1 \%$ o

$6045 \pm 60$

4095 B.c.

$\delta C^{1 s}=-26.8 \%$ o

$\delta C^{13}=-24.6 \%$ 。 


\section{GrN-4312. Emmen A 2-1}

Tree rings 30 to 40 from Stump A 2.

General Comment: all samples pretreated with acid and alkali. For dendrochronologic correlation of stumps, see Vogel, Casparie, and Munaut (1969). Using known age differences between samples of individual stumps, mean dates of outermost samples per stump are 6945 \pm 15 for $\mathrm{D}^{\circ} 1,6150 \pm 15$ for $\mathrm{E}^{\circ} 1,6100 \pm 40$ for $\mathrm{E} 4,6260 \pm 13$ for $\mathrm{E}^{\circ}$ 4 , and $5920 \pm 45$ for $\mathrm{B} 2$. Dates indicate 3 main periods of local bog desiccation and overgrowth with Pinus forests, roughly ending at 7000 , 6000 , and 5000 в.P. respectively.

\section{GrN-4802. Klazienaveen 2}

$$
\begin{gathered}
\mathbf{4 6 0 0} \pm \mathbf{9 0} \\
\mathbf{2 6 5 0} \text { B.c. } \\
\delta C^{13}=-26.3 \% \circ
\end{gathered}
$$

Middle $1 \mathrm{~cm}$ of 2-cm-thick layer of dopplerite, forming transition of iron-rich seepage peat to Sphagnum peat in Sec. Emmen 19 at Klazienaveen-Noord. Depth 1.90 to $2.20 \mathrm{~m}$. In same stratigraphic position as Pinus stump Layer A, expected contemporary with GrN-4312. Coll. 1964. Comment: pretreated with acid only. Somewhat younger than expected.

\section{GrN-4625. Klazienaveen 1}

$\mathbf{4 4 4 0} \pm 70$

Outermost 25 to 30 tree rings of Pinus stump in dopplerite layer within Sphagnum peat at higher stratigraphic position in same sec. as preceding sample at Klazienaveen-Noord. Depth ca. $1.70 \mathrm{~m}$. Expected age ca. 2500 B.c. Coll. 1964. Comment: later occurrence of Pinus than in main periods of desiccation.

\section{GrN-4801. Splitting}

$$
\begin{aligned}
& 4360 \pm 55 \\
& 2410 \text { B.c. }
\end{aligned}
$$
Layer B in Sec. Emmen 29 at Splitting, $2 \mathrm{~km} \mathrm{E}$ of Bargeroosterveld. Depth $1.30 \mathrm{~m}$. Expected age ca. 3000 B.c. Coll. 1964. Comment: younger than main stump layer at Loc. A, about same age as preceding sample.

\section{GrN-4804. Bargercompascuum 3}

$4240 \pm 60$ 2290 B.C.

$$
\delta C^{13}=-26.6 \%
$$

Middle $1 \mathrm{~cm}$ of 2-cm-thick layer of dopplerite at transition of ironrich seepage peat and highly humified Sphagnum peat in Sec. Emmen 31 at Bargercompascuum. Depth ca. $1.70 \mathrm{~m}$. Expected age ca. 5000 B.P. Coll. 1964.

\section{GrN-4803. Bargercompascuum 2}


Upper $1 \mathrm{~cm}$ of lower of 2 layers of iron-poor fen peat of local occurrence within main Sphagnum peat formation. Same sec. as preceding sample. Depth ca. 1.20 m. Expected age 4500 to 3500 B.P. Coll. 1964.

\section{GrN-4626. Bargercompascuum 1}

$3870 \pm 60$

1920 B.C.

$\delta C^{13}=-26.9 \%$

Upper $1 \mathrm{~cm}$ of upper of 2 layers of iron-poor fen peat of local occurrence within main Sphagnum peat formation. Same sec. as preceding 2 samples. Depth ca. $0.80 \mathrm{~m}$. Coll. 1964. Expected age shortly before 4000 B.P.

General Comment: GrN-4804 (dopplerite) too young.

\section{GrN-4146. Emmererfscheidenveen GH 2}

\section{$3765 \pm 40$ \\ 1815 B.c.}

Upper $1 / 3 \mathrm{~cm}$ of highly humified Sphagnum peat just below "Grenzhorizont" in bog Sec. Emmen 11 at Emmererfscheidenveen. Depth 1.79 m. Coll. 1962.

\section{GrN-4148. Emmererfscheidenveen GH 1}

$$
\begin{gathered}
\mathbf{3 7 5 0} \pm \mathbf{4 0} \\
\mathbf{1 8 0 0} \text { B.C. } \\
\delta C^{13}=-26.2 \%
\end{gathered}
$$

Lower $1 / 3 \mathrm{~cm}$ of slightly humified Sphagnum peat in same sec. as preceding sample, just above "Grenzhorizont." Depth 1.79 m. Coll. 1962. General Comment: both samples pretreated with acid only. No significant difference between samples.

\section{GrN-4624. Emmererfscheidenveen- Groene Dijk 3}

$$
\begin{gathered}
\mathbf{3 8 4 0} \pm \mathbf{6 0} \\
1890 \text { B.c. } \\
\delta C^{1 s}=-27.3 \%
\end{gathered}
$$

Lower cm of moderately humified Sphagnum peat just above highly humified peat in tussock of Sphagnum peat in Sec. Emmen 17 at Emmererfscheidenveen (Tweede Groene Dijk). Depth 1.15 m. Coll. 1962. Comment: see Casparie (1969).

\section{GrN-4623. Emmererfscheidenveen- Groene Dijk 2}

$$
\begin{gathered}
2490 \pm 60 \\
540 \text { B.c. } \\
\delta C^{13}=-25.5 \%
\end{gathered}
$$

Upper $\mathrm{cm}$ of moderately humified Sphagnum peat, immediately below slightly humified Sphagnum peat in same sec. as preceding sample. Depth ca. $0.40 \mathrm{~m}$. Coll. 1962. Comment: see Casparie (1969).

General Comment: all samples pretreated with acid and alkali except where otherwise stated. Standard pollen sec. Emmen pub. in Science, 1958 , v. 127, p. 3293. From same bog are dates Zwartemeer (ibid., v. 128, p. 1552) and archaeol. dates Valthe (trackway( (ibid., v. 128, p. 1553), Nieuw-Dordrecht (trackway) (R., 1963, v. 5, p. 181), Bargeroosterveld (Bronze age sanctuary) (ibid., p. 191) and Emmererfscheidenveen series 
(2 trackways) (R., 1967, v. 9, p. 135). One trackway date, Emmererfscheidenveen- N foot-path, GrN-4622, below.

\section{GrN-5180. Lutterzand, Netherlands}

$7535 \pm 50$

5585 в.c.

$$
\delta C^{13}=-26.6 \% \text { o }
$$

Sandy peat on top of younger coversand in Late Glacial valley exposed in sec. on shore of Dinkel R. in Lutterzand near Denekamp $\left(52^{\circ} 22^{\prime} \mathrm{N}\right.$ Lat, $7^{\circ} 0^{\prime} \mathrm{E}$ Long), prov. of Overijssel, Netherlands. Depth $1.10 \mathrm{~m}$ below surface. Peat antedates dunesand formation with many peaty intercalations. Pollen analysis points to Late Boreal (Sub-Boreal age according to submitters). Coll. and subm. 1967 by E. Brinkman and T. van der Hammen, present address H. de Vries Lab., Univ. Amsterdam, Netherlands. Comment: pretreated with acid and cold alkali. Date confirms Late Boreal age, indicated by pollen diagram, and suggests Atlantic age for dune formation.

\section{Astense Peel series, Netherlands}

Pollen sequences in Astense Peel peat bog near Ospel $\left(51^{\circ} 18^{\prime} \mathrm{N}\right.$ Lat, $5^{\circ} 46^{\prime} \mathrm{E}$ Long), prov. of Noord-Brabant, Netherlands, were studied 1957 by the late F. Florschütz and 1965 in greater detail by C. R. Jansen, Bot. Mus., Univ. Utrecht, Netherlands. The 1st sec. (Astense Peel), intended to be a standard pollen sec., was coll. and subm. 1957 by F. Florschütz. In 2nd sec. (Groote Peel), 2 prehistoric and 2 historic cultivation levels can be distinguished. Samples from this sec. coll. by C. R. Jansen from exposure down to $1.35 \mathrm{~m}$ and boring down to $1.60 \mathrm{~m}$ in 1965; subm. 1966 and 1968.

\section{GrN-1585. Astense Peel 1} Atlantic.

Peaty clay, depth 2.89 to $2.90 \mathrm{~m}$, at base of sec. Boundary Boreal/

\section{GrN-1595. Astense Peel 6}

$5350 \pm 80$

Birch stem, depth 2.00 to $2.07 \mathrm{~m}$. Strong increase of Alnus and Corylus. Atlantic or Sub-Boreal.

GrN-1586. Astense Peel 3

Peat, depth 0.82 to $0.83 \mathrm{~m}$. Beginning of strong decrease of Corylus; increase of Fagus; beginning of continuous Carpinus curve. Presumably Sub-Boreal.

GrN-1593. Astense Peel 4

$1380 \pm 55$

Older Sphagnum peat, 0.26 to $0.27 \mathrm{~m}$. Sub-Boreal or Sub-Atlantic.

GrN-1594. Astense Peel 5

$1230 \pm 50$

Younger Sphagnum peat at 0.24 to 0.25 b. Sub-Boreal or SubAtlantic. 
GrN-5163. Groote Peel 1

Peat from 1.29 to $1.31 \mathrm{~m}$ depth at 2nd prehistoric cultivation level with minimum in Tilia curve.

\section{GrN-5165. Groote Peel 2}

$\delta C^{13}=-26.3 \%$ pansion.

Peat from 0.72 to $0.74 \mathrm{~m}$ depth marking beginning of Fagus ex-

\section{GrN-5164. Groote Peel 3}

$1885 \pm 40$ A.D. 65

$\delta C^{13}=-26.9 \%$

Peat from 0.57 to $0.59 \mathrm{~m}$ depth, marking 1st Fagus maximum and first "historic" cultivation level (Cerealia max.).

\section{GrN-5166. Groote Peel 4}

$$
1225 \pm 40
$$

\section{A.D. 725}

$\delta C^{13}=-26.4 \%$

Peat from $0.20 \mathrm{~m}$ depth, marking 2nd Fagus maximum just before 2nd "historic" cultivation level.

General Comment: Samples 2 and 3 were initially interchanged at some stage. To gain complete certainty check samples were subm. 1968.

\section{GrN-5619. Groote Peel GRP 1}

$4510 \pm 85$

2560 B.C.

$$
\delta C^{1 s}=-27.4 \%
$$

Peat from 1.57 to $1.60 \mathrm{~m}$ depth in boring, marking 1st occurrence of Plantago lanceolata (landnam) and Ulmus decline.

GrN-5621. Groote Peel GRP 3

$$
\begin{aligned}
& 3100 \pm 50 \\
& 1150 \text { B.C. } \\
& \delta C^{13}=-24.7 \%
\end{aligned}
$$

Peat from 0.71 to $0.72 \mathrm{~m}$ depth in same profile as $\mathrm{GrN}-5165$, above (check sample).

GrN-5620. Groote Peel GRP 2

Peat from 0.55 to $0.58 \mathrm{~m}$ depth in same profile as $\mathrm{GrN}-5164$, above (check sample).

General Comment: all samples pretreated with acid only. Check samples confirm dating and order of lst Groote Peel series. Fagus increase is contemporeaneous in both secs. (Samples Astense Peel 3 and Groote Peel 2).

\section{Schipluiden series, Netherlands}

Alternating peat and clay layers in boring at Schipluiden $\left(51^{\circ} 58^{\prime}\right.$ N Lat, $4^{\circ} 42^{\prime}$ E Long), prov. of Zuid-Holland, Netherlands. Top of 
profile is $-2.80 \mathrm{~m}$. Pollen diagram prepared by A. A. Hartman (1968). Absolute quantity of pollen precipitation per year calculated from analysis data (Hartman, 1968). Coll. 1966 by Geol. Survey of the Netherlands; subm. 1967 by T. van der Hammen, H. de Vries Lab., Univ. Amsterdam, Netherlands.

GrN-5143. Schipluiden $4.69 \mathrm{~m}$ $6020 \pm 70$

Lower peat layer at 4.69 to $4.70 \mathrm{~m}$ depth. Pollen zone Atlantic. Decrease of Corylus.

GrN-5459. Schipluiden $4.35 \mathrm{~m}$ $5740 \pm 110$ 3790 B.c.

Thin gyttja layer on top of lower peat layer at 4.35 to $4.38 \mathrm{~m}$ depth. Pollen zone Atlantic. Corylus low.

\section{GrN-5380. Schipluiden $3.60 \mathrm{~m}$}

$5050 \pm 45$

3100 B.c.

$\delta C^{13}=-26.7 \%$

Lower part of 2nd peat layer at $3.60 \mathrm{~m}$ depth. Pollen zone SubBoreal (after Ulmus decline). Corylus low.

\section{GrN-5328. Schipluiden $3.10 \mathrm{~m}$}

$4785 \pm 60$ 2835 B.C.

Top of 2nd peat layer at 3.10 to $3.13 \mathrm{~m}$ depth. Pollen zone SubBoreal. Corylus high.

\section{GrN-5379. Schipluiden $2.25 \mathrm{~m}$}

$4430 \pm 60$ 2480 в.c.

Base of 3rd peat layer at $2.25 \mathrm{~m}$ depth. Pollen zone Sub-Boreal Corylus low.

\section{GrN-5378. Schipluiden $1.25 \mathrm{~m}$}

Middle of 3 rd peat layer at $1.25 \mathrm{~m}$ depth. Pollen zone Sub-Boreal. First increase of Fagus.

\section{GrN-5327. Schipluiden $1.23 \mathrm{~m}$}

Peaty gyttja intercalation in 3rd peat layer at $1.23 \mathrm{~m}$ depth. Pollen zone Sub-Boreal. First increase of Fagus; 1st occurrence of Carpinus.

\section{GrN-5377. Schipluiden $1.05 \mathrm{~m}$}

$$
\begin{array}{r}
\mathbf{3 6 0 5} \pm \mathbf{5 0} \\
\mathbf{1 6 5 5} \text { B.C. } \\
\delta C^{1 s}=-27.4 \% o
\end{array}
$$

Peat at $1.05 \mathrm{~m}$ depth. Pollen zone Sub-Boreal. Fagus absent; 1st occurrence of Plantago lanceolata. 
GrN-5329. Schipluiden $0.57 \mathrm{~m}$

Top of 3rd peat layer at 0.57 to $0.60 \mathrm{~m}$ depth. Pollen zone SubBoreal. Second increase of Fagus.

General Comment: all samples pretreated with acid only. GrN-5378 and probably GrN-5327 appear too young, which, according to Hartman, may be due to contamination. Or peaty material and gyttja may have been deposited under uplifted floating peat (Troels-Smith, 1960).

\section{GrN-5238. Vlaardingen peat, Netherlands}

$$
\begin{gathered}
2960 \pm 55 \\
1010 \text { в.C. } \\
\delta C^{13}=-27.9 \% \circ
\end{gathered}
$$

Base of peat layer from boring at depth 1.27 to $1.30 \mathrm{~m}$ below surface clay deposits at Vlaardingen $\left(51^{\circ} 54^{\prime} \mathrm{N}\right.$ Lat, $4^{\circ} 21^{\prime} \mathrm{E}$ Long), prov. of Zuid-Holland. Lower clay layer (gully deposit) wedges out laterally into peat above which occur Early Iron age remains. Date should prove this correlation, which did not fit in with current views on geology of area. Coll. and subm. 1967 by J. D. de Jong, Geol. Dienst, Haarlem; subm. by J. F. van Regteren Altena, Rijksdienst voor het Oudheidkundig Bodemonderzoek, Amersfoort, Netherlands. Comment: date proves high age of underlying clay and confirms stratigraphic observation. For date of Iron age settlement in peat layer in same area see GrN-1951: $2320 \pm 70$ (Broekpolder, R., 1963, v. 5, p. 193).

\section{GrN-4601. Oosterhout, Netherlands}

$2980 \pm 70$ 1030 B.c.

Charcoal pieces from thin layer of heavy clay in river at 1.05 to $1.10 \mathrm{~m}$ depth in boring near Oosterhout, Elst $\left(51^{\circ} 55^{\prime} \mathrm{N}\right.$ Lat, $5^{\circ} 51^{\prime}$ E Long), prov. of Gelderland, Netherlands. Coll. 1963 by A. J. Havinga; subm. 1964 by B. Polak, Landbouwhogeschool, Wageningen, Netherlands. Comment: pretreated with acid and alkali.

\section{GrN-4371. Bunnik, Netherlands}

$$
\begin{gathered}
2930 \pm 60 \\
980 \text { B.C. } \\
\delta C^{13}=-24.7 \% o
\end{gathered}
$$

Charcoal pieces from continuous layer at 0.83 to $0.86 \mathrm{~m}$ depth between overlying river clay and underlying clayey peat and peat in pit near Bunnik (52 $4^{\prime} \mathrm{N}$ Lat, $5^{\circ} 12^{\prime} \mathrm{E}$ Long), prov. of Utrecht. Pollen diagram of peat indicates Late Sub-Boreal. Coll. 1963 and subm. 1964 by the late K. J. Zandstra, Wageningen. Comment: pretreated with acid and alkali. Date was expected.

\section{GrN-4600. Hellouw, Netherlands}

Small charcoal pieces in dark gray, very heavy clay layer (laklaag), at 0.55 to $0.65 \mathrm{~m}$ depth, formed during interruption of clay deposition in river marsh near Hellouw, Haaften (51 $48^{\prime} \mathrm{N}$ Lat, $5^{\circ} 13^{\prime} \mathrm{E}$ Long), 
prov. of Gelderland. Expected age ca. 2000 B.P. Coll. 1963 by A. J. Havinga; subm. 1964 by B. Polak. Comment: pretreated with acid and cold alkali.

\section{West-Friesland series, Netherlands}

In W-Friesland, prov. of Noord-Holland between towns Alkmaar, Medemblik, Enkhuizen, and Hoorn (52 $38^{\prime} \mathrm{N}$ Lat, $5^{\circ} 4^{\prime}$ E Long), studies revealed sequence of Sub-Boreal marine intrusions, interrupted by periods of fresh-water peat formation in depressions and possible human habitation on elevated parts (Pons and Wiggers, 1960; Kwaad, 1961; Kwaad et al., 1965; du Burck and Dekker, 1968). Marine deposits are called Beemster, Wieringermeer, Westfrisian I, Westfrisian II, and Westfrisian III.

\section{GrN-1583. Zandwerven shells}

$4670 \pm 55$

Shell bank (mainly Cardium edule) below sand ridge at Zandwerven, Spanbroek ( $52^{\circ} 41^{\prime} \mathrm{N}$ Lat, $4^{\circ} 56^{\prime} \mathrm{E}$ Long). Shells indicate marine environment. Subm. by the late J. P. Bakker, Phys. Geog. Lab., Univ. Amsterdam. Comment: date of Neolithic settlement (Vlaardingen culture) on ridge GrN-2221: $4000 \pm 65$, this list.

\section{GrN-2386. Hoorn 2}

Base of peat atop Beemster clay in profile at Westerblokker near Hoorn (52 $38^{\prime} \mathrm{N}$ Lat, $5^{\circ} 4^{\prime} \mathrm{E}$ Long). Depth 4.07 to $4.12 \mathrm{~m}$. Coll. and subm. by F. J. P. M. Kwaad, Phys.-Geog. Lab., Univ. Amsterdam.

\section{GrN-2379. Hoorn 1}

$3760 \pm 60$ 1810 B.c.

Top of same peat layer at depth 3.38 to $3.43 \mathrm{~m}$, underlying Westfrisian deposits. Comment: thin peat layer at 1.10 to $1.20 \mathrm{~m}$ depth in same sec. separates Westfrisian I and II deposits.

\section{GrN-4619. Oostmijzen}

$4485 \pm 85$

Thin gyttja layer over clay and under peat at 0.92 to $0.95 \mathrm{~m}$ depth in boring at Oostmijzen ( $52^{\circ} 36^{\prime} \mathrm{N}$ Lat, $4^{\circ} 56^{\prime} \mathrm{E}$ Long). Coll. 1964 by P. du Burck, Stichting voor Bodemkartering, Bennekom; subm. 1965 by G. C. Maarleveld.

\section{GrN-2389. Wadwaaij 3}

$4420 \pm 85$

2470 в.c.

Top of peat underlying clay, probably belonging to Wieringermeer formation at Wadwaaij, Spanbroek (52 $41^{\prime} \mathrm{N}$ Lat, $4^{\circ} 56^{\prime} \mathrm{E}$ Long), $2 \mathrm{~km} \mathrm{E}$ of Zandwerven sand ridge. Clay below peat probably Beemster deposit. Depth 2.18 to $2.23 \mathrm{~m}$. This and 2 following samples subm. by the late J. P. Bakker. 
GrN-2975. Wadwaaij 2

$4125 \pm 75$

Base of peat overlying Wieringermeer clay, at 1.72 to $1.77 \mathrm{~m}$ depth in same sec. as preceding sample.

\section{GrN-2382. Wadwaaij 1}

$3935 \pm 100$

depth, antedating overlying Westfrisian deposits.

\section{GrN-2499. Berkhout}

$4230 \pm 75$

2280 B.C.

Base of peat overlying Beemster deposit at Berkhout $\left(52^{\circ} 38^{\prime} \mathrm{N}\right.$ Lat, $4^{\circ} 57^{\prime}$ E Long). Subm. by L. J. Pons. Comment: date suggests either hiatus or wrong attribution of clay deposit.

GrN-4620. Opmeer 1

$4150 \pm 80$ 2200 B.C.

$\delta C^{13}=-23.6 \%$

Thin layer of fen-peat intercalated between clay at 1.16 to 1.18 $m$ depth in boring at Opmeer (52 $42^{\prime} \mathrm{N}$ Lat, $4^{\circ} 56^{\prime} \mathrm{E}$ Long). Coll. 1964 by P. du Burck; subm. 1965 by G. C. Maarleveld.

GrN-4621. Opmeer 2

$3635 \pm 75$ 1685 B.c.

$\delta C^{13}=-26.4 \%$

Humic layer in same boring as preceding sample at 0.65 to 0.67 $\mathrm{m}$ depth. Deposit between both samples consists of clay and sandy clay attributed to Westfrisian I formation.

\section{GrN-5555. Hoogwoud 2}

$4160 \pm 65$

2210 B.P.

$\delta C^{13}=-25.7 \%$

Thin layer of humic clay between clay deposits at 0.98 to $1.02 \mathrm{~m}$ depth in profile pit at Hoogwoud (52 $42^{\prime} \mathrm{N}$ Lat, $4^{\circ} 56^{\prime} \mathrm{E}$ Long). Coll. and subm. 1967 by P. du Burck.

\section{GrN-5554. Hoogwoud 1}

$3440 \pm 90$

1490 B.c.

$\delta C^{1 s}=-26.4 \%$

Thin layer of humic clay in same profile pit as preceding sample at 0.61 to $0.625 \mathrm{~m}$ depth. According to preliminary interpretation, lower humic layer should represent dividing line between Westfrisian I and Westfrisian II formations. Comment: dates suggest upper humic layer to separate Westfrisian I and II deposits (see Opmeer, above).

\section{GrN-5553. Zuidscharwoude 2}

$$
\begin{gathered}
\mathbf{3 8 0 0} \pm \mathbf{4 5} \\
1850 \text { B.c. } \\
\delta C^{1 s}=-27.5 \%
\end{gathered}
$$

Base of peat at 1.14 to $1.17 \mathrm{~m}$ depth atop heavy clay in boring at Zuidscharwoude $\left(52^{\circ} 42^{\prime} \mathrm{N}\right.$ Lat, $4^{\circ} 49^{\prime} \mathrm{E}$ Long). According to pre- 
liminary interpretation, clay should be earlier than Westfrisian I. Coll. and subm. as samples from Hoogwoud.

GrN-5552. Zuidscharwoude 1

$3500 \pm 45$

1550 в.c.

Top of same peat as preceding sample at 0.66 to $0.69 \mathrm{~m}$ depth. Overlying clay presumably Westfrisian. Coll. and subm. as above. Comment: date indicates that clay layers belong to Westfrisian I and II deposits, respectively.

GrN-611. Grootslag

$3155 \pm 110$ Zwaagkdijk (52 $42^{\prime} \mathrm{N}$ Lat, $5^{\circ} 9^{\prime} \mathrm{E}$ Long). Subm. by P. J. Ente.

\section{GrN-823. Warmenhuizen}

$2950 \pm 85$

Organic layer atop marine deposit, possibly Westfrisian III, at Warmenhuizen (52 $43^{\prime} \mathrm{N}$ Lat, $4^{\circ} 44^{\prime} \mathrm{E}$ Long). Subm. 1958 by P. du Burck.

\section{GrN-3546. Wogmeer}

$2930 \pm 80$

980 B.c.

Lowermost $1 \mathrm{~cm}$ peat over tidal flat clay, SW of Zandwerven sand ridge at Wogmeer (52 $39^{\prime} \mathrm{N}$ Lat, $4^{\circ} 55^{\prime}$ E Long). Coll. 1961; subm. by W. Glasbergen, Inst. v. Pre- en Protohistorie, Univ. Amsterdam. Comment: all samples pretreated with acid; GrN-4621, $-5552-55$ also extracted with cold alkali. Date suggests prolonged tidal flat sedimentation W of Zandwerven sand ridge (van Regteren Altena et al., 1963). General Comment: dates should be compared with those from standard sec. Hauwert (Science, 1958, v. 127, p. 131) GrN-605: $4690 \pm 140$ for base of peat layer between Beemster and Wieringermeer deposits, GrN610: $4090 \pm 120$ for thin peat layer between Wieringermeer and Westfrisian I deposits, GrN-609: $3750 \pm 120$ for thin peat layer between Westfrisian I and II deposits, and GrN-617: $3240 \pm 140$ for shells within Westfrisian II clay. Based on peat dates, the following estimates can be made for main periods of marine clay sedimentation: Beemster ? to 4800 , Wieringermeer 4400 to 4200 , Westfrisian I 4000 to 3800 , Westfrisian II 3400 to 3200 , Westfrisian III 3100 to 3000 . Settlement of Vlaardingen culture on Zandwerven sand ridge dated GrN-221: 2040 \pm 65 , this list. Bell Beaker culture settlement occurs on Westfrisian I deposit at Oostwoud (van Giffen, 1962). Bronze age settlements occur at various places, e.g., over Westfrisian II deposits at Zwaagdijk with date GrN-4243: $3200 \pm 60$ (R., 1967, v. 9, p. 134). For dates from Bronze age barrows in area, ranging from 3025 to 2965, see Wervershoof series (R., 1963, v. 4, p. 191). For dates from Bronze age barrow and Iron age settlement at Hoogkarspel, see this list. 


\section{Holocene of Other Countries}

\section{Niederwil bog series, Switzerland}

In addition to investigation of a Neolithic settlement in bog (Egelsee) at Niederwil, Gem. Gachnang, near Frauenfeld $\left(47^{\circ} 34^{\prime} \mathrm{N}\right.$ Lat, $8^{\circ} 54^{\prime}$ E Long), Thurgovia, Switzerland (Waterbolk and van Zeist, 1967), boring was made into deeper levels. Simplified pollen diagram by J. M. Matthews with $\mathrm{C}^{14}$ dates pub. by Vogel (1970) and compared with diagram for Faulenseemoos to study $\mathrm{C}^{14}$ trends in atmosphere before 6000 B.P. Coll. 1963 by W. van Zeist.

\section{GrN-4951. Niederwil 6.90 to $6.99 \mathrm{~m}$ \\ $12,780 \pm 110$ \\ 10,830 B.C. \\ $\delta C^{13}=-21.1 \%$}

Gyttja at depth 6.90 to $6.99 \mathrm{~m}$. Betula dominant, Pinus very low.

\section{GrN-5203. Niederwil 6.00 to $6.08 \mathrm{~m}$}

$$
\begin{gathered}
10,680 \pm 90 \\
8730 \text { B.C. }
\end{gathered}
$$

Gyttja at depth 6.00 to $6.08 \mathrm{~m}$. Pinus dominant, Betula low.

\section{GrN-4952. Niederwil 5.60 to $5.68 \mathrm{~m}$}

$$
\begin{gathered}
10,310 \pm 125 \\
8360 \text { B.C. }
\end{gathered}
$$

Gyttja at depth 5.60 to $5.68 \mathrm{~m}$. Pinus and Betula high, Corylus low, just before sharp increase.

\section{GrN-5355. Niederwil 5.11 to $5.18 \mathrm{~m}$}

$9000 \pm 100$ 7050 B.C.

$$
\delta C^{13}=-21.2 \%
$$

Gyttja at depth 5.11 to $5.18 \mathrm{~m}$. Pinus low. Quercetum mixtum high. Corylus peak.

\section{GrN-4987. Niederwil 4.31 to $4.39 \mathrm{~m}$}

$8170 \pm 80$ 6230 B.c. high.

Gyttja at depth 4.31 to $4.39 \mathrm{~m}$. Quercetum mixtum and Corylus

\section{GrN-5354. Niederwil 3.50 to $3.60 \mathrm{~m}$}

$7660 \pm 80$ $\mathbf{5 7 1 0 ~ B . C . ~}$ $\delta C^{13}=-16.9 \%$

Gyttja at depth 3.50 to $3.60 \mathrm{~m}$. Quercetum mixtum and Corylus high. First occurrence of Abies. Just before appearance of Fagus.

\section{GrN-4955. Niederwil 2.80 to $3.10 \mathrm{~m}$}

$7010 \pm 60$ 5060 B.c. $\delta \mathrm{C}^{13}=-16.9 \%$

Gyttja from depths 2.80 to 2.98 and 3.00 to $3.10 \mathrm{~m}$. Comment: sample pretreated with dilute acid and cold alkali. 


\section{GrN-4954. Niederwil 2.90 to $2.98 \mathrm{~m}$}

$$
\begin{gathered}
\mathbf{7 1 0 0} \pm \mathbf{7 0} \\
\mathbf{5 1 5 0} \text { B.c. } \\
\delta G^{13}=-16.3 \%
\end{gathered}
$$

Gyttja from depth 2.90 to $2.98 \mathrm{~m}$. Quercetum mixtum and Corylus high. Fagus increasing.

\section{GrN-5353. Niederwil 2.51 to $2.58 \mathrm{~m}$}

$6120 \pm 75$

4170 B.C.

Gyttja from depth 2.51 to $2.58 \mathrm{~m}$. First maximum of Fagus.

\section{GrN-5202. Niederwil 2.00 to $2.09 \mathrm{~m}$}

$$
\begin{gathered}
4960 \pm 80 \\
3010 \text { B.c. } \\
\delta C^{13}=-22.3 \% o
\end{gathered}
$$

Gyttja from depth 2.00 to $2.09 \mathrm{~m}$. Cerealia and other culture indicators present.

General Comment: since no significant difference between GrN-4955 on fully pretreated sample and GrN-4954 on sample pretreated with acid only, other samples were pretreated with acid only. For more dates of Swiss pollen sequences, see R., 1970, v. 12, p. 359-379. Dates from Neolithic settlement Niederwil pub. in R., 1967, v. 9, p. 132.

\section{GrN-854. Fagne Wallone, Belgium}

$6825 \pm 70$

Wood (Betula) from base of peat layer at depth 1.80 to $2.00 \mathrm{~m}$ in Fagne Wallone $\left(50^{\circ} 31^{\prime} \mathrm{N}\right.$ Lat, $6^{\circ} 7^{\prime} \mathrm{E}$ Long), Belgium. Wood overlain by $0.25 \mathrm{~m}$ of Atlantic Scheuchzeria peat and $1.50 \mathrm{~m}$ of Sub-Boreal Eriophorum vaginatum peat. Alt. 643 m. Coll. 1958 by R. Bouillenne and M. Streel, Univ. Liege, Belgium; subm. by the late F. Florschütz.

\section{GrN-4492. Beune valley, France}

$9040 \pm 55$ 7090 B.c.

Dark brown silty mud from 13.40 to $13.90 \mathrm{~m}$ depth in Boring II in valley deposit of Beune R. (44 $56^{\prime} \mathrm{N}$ Lat, $1^{\circ} 42^{\prime} \mathrm{W}$ Long), 3.5 $\mathrm{km} \mathrm{E}$ of Les Eyzies, Périgord (Donner, 1969). Pollen diagram shows for sampled depth steep decrease of Pinus, increase of Quercus and steep increase of Corylus, interpreted as beginning of postglacial. Coll. 1963 and subm. 1964 by J. J. Donner, Dept. Geol. and Paleontol., Univ. Helsinki, Finland. Comment: pretreated with acid only. Two small samples ( 13.65 to $13.90 \mathrm{~m}$ and 13.45 to $13.65 \mathrm{~m}$ ) taken together. Since main changes in pollen diagram occur in lower sample and relative organic content of both samples is unknown, date may apply to level after major vegetational changes and thus not contradictory to date Q-617: 9960 \pm 160 for Corylus rise in diagram of boring La Moura near Biarritz (R., 1964, v. 6, p. 132). In this interpretation level 14.20 to $13.90 \mathrm{~m}$ with absence of Quercus and Corylus, and Pinus dominance, could be equivalent to Upper Dryas period and level 15.20 to $14.20 \mathrm{~m}$ with maxima for 
Quercus (low) and Corylus (medium) would suggest Aller $\phi \mathrm{d}$ period. But submitter considers presence of Quercus and Corylus pollen in these sand and silt levels due to contamination. He attributes whole sequence to postglacial (Donner, 1969).

\section{GrN-2043. Fromentine, France}

$7430 \pm 100$

5480 B.c.

Thin sedge peat layer from boring at $9.50 \mathrm{~m}$ depth below sand and clay on Atlantic coast at Fromentine, commune de la Barre-de-Monts $\left(46^{\circ} 53^{\prime} \mathrm{N}\right.$ Lat, $2^{\circ} 9^{\prime} \mathrm{W}$ Long), Vendée, France. Surface $+2.40 \mathrm{~m}$. Pollen analysis indicates Early Atlantic age of peat (Quercus dominant, Pinus declining) (Verger and Florschütz, 1960). Coll. 1957 by F. Verger, C.N.R.S., Paris, France; subm. 1959 by the late J. P. Bakker. Comment: pretreated with acid only. Date as expected.

\section{Estany series, Spain}

Three samples dated from peat and clay in former volcanic crater Estany near Olot near Gerona (ca. $42^{\circ} 10^{\prime} \mathrm{N}$ Lat, ca. $2^{\circ} 31^{\prime} \mathrm{E}$ Long), Spain (Menéndez Amor, 1964). Sec. consists of clay, peat, clayey gyttja, peat, gyttja and clay. Subm. by the late F. Florschütz.

\section{GrN-2850. Estany 4.10 to $4.23 \mathrm{~m}$}

$4090 \pm 75$

Peat at depth 4.10 to 4.23 m. Quercus dominant, Corylus low, all other trees very low.

GrN-2839. Estany 3.40 to $3.50 \mathrm{~m}$

$3200 \pm 65$ 1250 B.C.

Peat at depth 3.40 to $3.50 \mathrm{~m}$. Quercus dominant, Fagus, Pinus, and Corylus ca. $10 \%$.

GrN-2837. Estany 2.37 to $2.50 \mathrm{~m}$ ca. $10 \%$, Corylus very low.

\section{E. Africa, Asia}

\section{GrN-4853. Gundumi, Nigeria}

$2230 \pm 55$

280 B.C.

$\delta C^{13}=-27.1 \%$

Charcoal particles from distinct, sloping layer in Sangiwa coversand at Gundumi (ca. $13^{\circ} \mathrm{S}$ Lat, $5^{\circ} 30^{\prime} \mathrm{E}$ Long), Sokoto prov., N Nigeria. Depth 0.40 to $0.80 \mathrm{~m}$. Date should be approx. minimum for formation of sandy wash plain on flat surface covered by sheet erosion during "pluvial" period. Expected age Middle to Late Pleistocene. Subm. 1965 by I. S. Zonneveld, FAO, Rome, and F. A. van Baren, Koninklijk Inst. v. de Tropen, Amsterdam, Netherlands. Comment: pretreated with acid only. Much younger than expected.

\section{GrN=4873. Gölbasi, Turkey}

$3080 \pm 115$

1130 B.c.

Pollen sequence was studied in middle of 3 lakes in upper reaches 


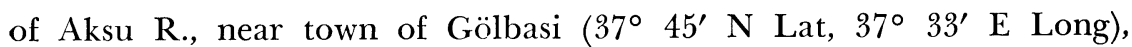
Adiyaman Vilayet, Turkey. Boring reached $13.45 \mathrm{~m}$ depth. Sample (marl with clay bands) taken at 13.20 to $13.45 \mathrm{~m}$. Alt $890 \mathrm{~m}$. Pollen diagram shows high arboreal pollen values with Quercus dominant, prior to destruction of upland forest. Quercus declines at depth $12.50 \mathrm{~m}$ (van Zeist et al., 1971). Coll. 1964 and subm. by W. van Zeist, Biol.-Archeol. Inst., Univ. Groningen, Netherlands. Comment: pretreated with acid only.

\section{GrN-4874. Bozova, Turkey}

$2590 \pm 70$

Pollen sequence studied in larger of 2 small lakes $\left(37^{\circ} 21^{\prime} \mathrm{N}\right.$ Lat, $38^{\circ} 31^{\prime}$ E Long), SW of Bozova, Urfa Vilayet, Turkey. Boring reached $4.80 \mathrm{~m}$ depth, but only sec. 0.85 to $1.85 \mathrm{~m}$ suitable for pollen analysis. Sample dated (humic clay) from 1.78 to $1.90 \mathrm{~m}$. Alt ca. $600 \mathrm{~m}$. Pollen diagram suggests treeless upland vegetation (van Zeist et al., 1971). Coll. 1964 and subm. by W. van Zeist. Comment: pretreated with acid only.

\section{Dead Sea series, Israel}

In Dead Sea basin and Jordan valley extensive sediments of mainly calcium carbonate, deposited from former lake Lisan, provided material for dating by $\mathrm{C}^{14}$ and Uranium-Thorium. Both methods give approx. same results (Kaufman and Vogel, ms. in preparation). Two profiles analyzed. Samples from Loc. I $\left(31^{\circ} 20^{\prime} \mathrm{N}\right.$ Lat, $35^{\circ} 20^{\prime} \mathrm{E}$ Long) coll. 1963 by D. Neev and J. C. Vogel and those from Loc. II $\left(31^{\circ} 10^{\prime} \mathrm{N}\right.$ Lat, $35^{\circ} 20^{\prime} \mathrm{E}$ Long) coll. 1965 by A. Kaufman, Weizmann Inst., Rehovoth, Israel.

GrN-4411. Lisan I, $19 \mathrm{~m}$

$25,800 \pm 240$ 23,850 B.c.

Carbonate from ca. $19 \mathrm{~m}$ below top of Lisan Formation at Loc. I in storm water gully leading to Dead Sea.

\section{GrN-4401. Lisan I, $14 \mathrm{~m}$}

$35,000 \pm 900$ 33,050 в.c. $\delta C^{13}=+0.6 \%$

Carbonate from $14 \mathrm{~m}$ below top of Upper Lisan Formation and close to base, at Loc. I.

\section{GrN-4402. Lisan I, $10 \mathrm{~m}$}

$31,400 \pm 310$ 29,450 в.C. $\delta C^{13}=+0.1 \% 0$

Carbonate from $10 \mathrm{~m}$ below top of Lisan Formation at Loc. I.

\section{GrN-4403. Lisan I, 1 m}

$16,300 \pm 75$ 14,350 в.с. $\delta C^{13}=0.0 \%$

Carbonate from $1 \mathrm{~m}$ below top of Lisan Formation at Loc. I representing last carbonate precipitated from Lake Lisan before contraction of Lake. 


\section{GrN-4844. Lisan 36-VC}

$33,850 \pm 510$ 31,900 в.c. $\delta C^{13}=+0.3 \%$ o

GrN-4843. Lisan 36-FC

$\mathbf{3 3 , 8 0 0} \pm 530$

31,850 в.c.

$\delta C^{13}=+0.7 \%$

Carbonate from $26 \mathrm{~m}$ below top and $8 \mathrm{~m}$ below base of Upper Lisan Formation. Comment: fraction VC and FC measured separately, as below.

GrN-4841. Lisan 35 B-VC, 12 m

GrN-4842. Lisan 35 B-FD, 12 m
$29,000 \pm 380$

27,050 в.c.

$\delta C^{13}=+1.7 \%$ o

$29,900 \pm 530$

27,950 в.c.

$\delta C^{1 s}=+0.8 \%$ o

Carbonate from $12 \mathrm{~m}$ below surface of Lisan Formation at Loc. II. Comment: Fraction VC and FD measured separately, as below.

\section{GrN-4837. Lisan 35 D-VC, 0 m}

\section{GrN-4838. Lisan 35 D-FD, 0 m}

$15,150 \pm 110$ 13,200 в.c. $\delta C^{13}=+1.5 \%$

$16,100 \pm 150$ 14,150 в.c. $\delta C^{13}=+1.8 \%$ o

Carbonate from top of Lisan Formation at Loc. II. Comment: layered sediment separated into very clear, fairly clear, fairly dark, and very dark fractions by Kaufman. Very clear (VC) and fairly dark (FD) fractions measured separately. Since dark fractions may contain secondary carbonate, VC fraction considered most reliable.

General Comment: no pretreatment nor correction for isotope fractionation applied. Samples from Lower Lisan Formation (GrN-4411 and GrN-4843) obviously contaminated by storm water occasionally wetting exposures near their base. Other dates show linear accumulation rate with age suggesting Upper Lisan Formation accumulated between ca. 36,000 B.P. and 15,000 B.P. Th- $U$ ages suggest accumulation between 38,000 B.P. and 17,000 B.P.

\section{Dacca series, Pakistan}

Geologic and pedologic studies in marine and estuarine deposits of Ganges R. and Brahmaputra R. made in Dacca and Barisal dist., E Pakistan, by Food and Agric. Organization of the U.N. Deep erosion gullies in Pleistocene terrace contain clay and intercalated peat layers. Clay can be traced far outside erosion gullies into estuarine plain deposits. Subm. 1966, 1967 by L. J. Pons, Lab. Regionale Bodemkunde, Wageningen, Netherlands. 
GrN-4939. Jatrabari, $3.00 \mathrm{~m}$

Peat (lower part of Lower Layer) from $3.00 \mathrm{~m}$ depth in boring at Jatrabari $\left(25^{\circ} 42^{\prime} \mathrm{N}\right.$ Lat, $90^{\circ} 27^{\prime} \mathrm{E}$ Long), Dacca dist. Coll. 1965 by Mr. Brinkman.

\section{GrN-5077. Jatrabari, $2.80 \mathrm{~m}$}

$1430 \pm 70$

A.D. 520

$\delta C^{13}=-24.2 \%$ above.

Peat (upper part of Lower Layer) from $2.80 \mathrm{~m}$ depth, same sec. as

GrN-4938. Jatrabari, $2.00 \mathrm{~m}$

$2790 \pm 50$

840 B.c.

Peat (Middle Layer) from $2.00 \mathrm{~m}$ depth, same sec.

$$
\delta C^{13}=-23.4 \%
$$

GrN-4937. Jatrabari, 0.60 m

$$
5030 \pm 70
$$

3080 B.c.

$\delta C^{13}=-30.5 \%$

Peat (Upper Layer) at $0.60 \mathrm{~m}$ depth under sand. Peat mostly at surface.

General Comment: pretreated with acid only. Dates strongly suggest interchange of samples GrN-5077 and GrN-4937.

GrN-5451. Fatulla, extract

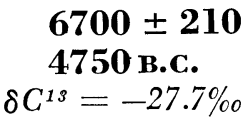

Organic acid sulphate layer at $3.60 \mathrm{~m}$ depth, underlying old Brahmaputra sediments at Fatulla police sta. (23 $27^{\prime} \mathrm{N}$ Lat, $90^{\circ} 28^{\prime} \mathrm{E}$ Long), Dacca dist. Coll. 1967. Comment: pretreated with acid and alkali. Since all organic matter dissolved in alkali, this fraction measured.

\section{GrN-5447. Ranipur}

A.D. 1040

$910 \pm 60$

$\delta C^{13}=-24.0 \%$

Organic material at 0.96 to $1.13 \mathrm{~m}$ depth buried between old Lower Meghna tidal change, at Ranipur village (22。 $40^{\prime} \mathrm{N}$ Lat, $90^{\circ} 3^{\prime} \mathrm{E}$ Long), Barisal dist. Coll. 1967. Comment: pretreated with acid and alkali.

GrN-5448. Umerpur

$805 \pm 40$

A.D. 1145

$\delta C^{13}=-26.7 \%$

Basin peat at 0.74 to $0.90 \mathrm{~m}$ depth of type intensively occurring at junction of tidal clay and flood-plain alluvium, at Umerpur village (22 $51^{\prime} \mathrm{N}$ Lat, $90^{\circ} 5^{\prime} \mathrm{E}$ Long), Barisal dist. Coll. 1967.

GrN-5449. Mahilara

$3040 \pm 145$

1090 B.C.

Organic clay buried at 0.92 to $1.02 \mathrm{~m}$ depth in old Lower Meghna 
estuarine flood-plain at Mahilara village ( $22^{\circ} 54^{\prime} \mathrm{N} \mathrm{Lat}, 90^{\circ} 17^{\prime} \mathrm{E}$ Long), Barisal dist. Date should be maximum for Ganges deposits, where older Brahmaputra deposits are buried in E part of delta. Coll. 1967.

GrN-5450. Gaurnadi

$1790 \pm 95$

\section{A.D. 160}

$\delta C^{13}=-25.9 \%$

Buried top soil at 0.72 to $0.92 \mathrm{~m}$ depth at boundary between old Lower Meghna and Ganges flood-plain alluvium at unnamed village near Gaurnadi police sta. (23० $0^{\prime} \mathrm{N}$ Lat, $90^{\circ} 12^{\prime} \mathrm{E}$ Long). Same stratigraphic position as above. Coll. 1967.

General Comment: latter 3 samples pretreated with acid and cold alkali. No clear correlations between Jatrabari gully deposits and delta samples yet possible. GrN-5449 and $\mathrm{GrN}-5450$ not as expected.

\section{ARCHAEOLOGIC SAMPLES}

\section{A. Southwest Asia}

\section{GrN-4404. Jabrud 6, Syria}

$25,850 \pm 4.10$

23,900 в.C.

Bone from Layer 6 in Rock Shelter I at Jabrud $\left(33^{\circ} 58^{\prime} \mathrm{N}\right.$ Lat, $36^{\circ} 39^{\prime}$ E Long), $10 \mathrm{~km}$ SW of Nebek and ca. $70 \mathrm{~km}$ NNE of Damascus, Syria, excavated ca. 1935 by A. Rust. Shelter contained 25 Middle Paleolithic layers down to $11.25 \mathrm{~m}$ depth. Layer 6 at ca. $1 \mathrm{~m}$ depth contained older Levallois or Acheulo-Mousterian and is above pre-Aurignacian layers (Rust, 1950). Obtained 1965 from Schwabedissen, Univ. Köln, Germany. Comment: all organic matter dissolved in dilute acid during extraction of inorganic salts. Collagen was thus partly decomposed. 4 $\mathrm{g}$ of organic matter from $380 \mathrm{~g}$ bone was separated from salts by dialysis and measured. Result obviously too young; contaminating humic substance was not removed by acid dialysis.

\section{GrN-5576. Ein Gev, Israel}

Charred bone coll. near burial with complete human skeleton at open-air Late Upper Paleolithic (Kebaran), site, Ein Gev $\left(32^{\circ} 46^{\prime} \mathrm{N}\right.$ Lat, $35^{\circ} 39^{\prime} \mathrm{E}$ Long), in Jordan valley on $\mathrm{E}$ shore of Lake Tiberias, $154 \mathrm{~m}$ below Mediterranean sea level. Depth $0.50 \mathrm{~m}$. Excavated by M. Stekelis and O. Bar-Yoseph, Dept. of Prehistoric Archaeol., Hebrew Univ., Jerusalem, Israel (Stekelis and Bar-Yoseph, 1965). Coll. 1964 by O. Bar-Yoseph. Comment: pretreated as for charred bone and alkali soluble fraction measured. Date agrees with general cultural sequence of Palestine.

\section{Beidha series, Jordan}

3 samples from Neolithic site of Beidha (30 $22^{\prime} \mathrm{N}$ Lat, $35^{\circ} 26^{\prime}$ E Long), Ma'an Dist., Jordan (Kirkbride, 1966a; 1966b). Coll. 1964 by H. Helbaek; subm. 1965 by D. Helbaek, Helsinge, Denmark. 
GrN-5063. Beidha, Level VI, E. 130

$$
\begin{array}{r}
\mathbf{8 6 0} \pm \mathbf{5 0} \\
\mathbf{6 6 9 0} \text { B.C. } \\
\delta C^{13}=-23.5 \% \circ
\end{array}
$$

Carbonized Pistacia nuts on floor of burnt house, sealed by plaster slag. Pre-pottery Neolithic, early phase. Sample may belong to Level V. Comment: pretreated with acid and alkali. Same sample as P-1379: $8546 \pm 100$ (R., 1969, v. 11, p. 152) and K-1082: $8710 \pm 130$ (R., 1968, v. 10, p. 324).

\section{GrN-5136. Beidha, Level IV, L. 411}

$\mathbf{8 8 1 0} \pm \mathbf{5 0}$ 6860 B.C.

Carbonized Pistacia wood from central post in burnt house. PrePottery Neolithic, early phase. Comment: pretreated with acid and alkali. Should be same sample as P-1380: $9128 \pm 103$ (R., 1969, v. 11, p. 152) and K-1083: $8640 \pm 160$ labelled Level V, L. 411 (R., 1968, v. 10, p. 324) and BM-111: $8790 \pm 200$ (R., 1968, v. 10, p. 4).

\section{GrN-5062. Beidha, Upper Level II, F 4. 300}

$$
\begin{gathered}
\mathbf{9 0 3 0} \pm \mathbf{5 0} \\
\mathbf{7 0 8 0} \text { в.C. } \\
\delta C^{13}=-20.7 \% \circ
\end{gathered}
$$

Carbonized wood (Juniperus cf. phoenicia), possibly lid of stonelined pit in burnt house. Pre-Pottery Neolithic, early phase. Comment: pretreated with acid and alkali. Should be same sample as P-1382: 8892 \pm 155 (R., 1969, v. 11, p. 152) and K-1085: $8550 \pm 160$ (R., 1968, v. 10, p. 324).

General Comment: dates do not follow stratigraphic order. Pistacia seed dates of 3 labs agree well, but other dates differ considerably. Some P and GrN samples may have been mislabeled. However, possibility should not be overlooked that high age of Juniperus and Pistacia trees causes wide scatter of charcoal dates.

\section{GrN-1544. Byblos, Lebanon}

$$
7360 \pm 70
$$

5410 B.c.

Charcoal from $0.50 \mathrm{~m}$ below undisturbed floor of Neolithic house in Sq. 0/6, Level XLIII at Byblos (Djebaïl) (34 $14^{\circ} 12^{\prime} \mathrm{N}$ Lat, $35^{\circ} 36^{\prime}$ E Long), Lebanon. Middle stage of Néolithique ancien. Coll. and subm. 1957 by M. Dunand. Comment: measurement by H. de Vries. Preliminary result sent to submitter in 1957 as $7000 \pm 80$ and pub. without GrN-number as $5043 \pm 80$ в.c. (Dunand, 1961; Watson, 1965). Compare W-627: $6550 \pm 200$ (R., 1960, v. 2, p. 183) for higher level in Néolithique ancien.

\section{Elâzíg series, Turkey}

Survey of Bronze Age sites, Élâzíg Vilayet (ca. $38^{\circ} 40^{\prime} \mathrm{N}$ Lat, $39^{\circ}$ 30' E Long), Turkey. Coll. and subm. 1967 by R. Whallon, Jr., Univ. Michigan, Mus. of Anthropol., Ann Arbor, Michigan. 
GrN-5284. Balibey N 52/3

$6175 \pm 50$

4225 в.C.

$\delta C^{13}=-24.4 \%$

Charcoal (Quercus sp.) from disturbed hearth near surface of Mound N 52/3, Nahiye of Balibey. Assoc. with materials from earliest Bronze age. Expected age: 3000 B.c.

GrN-5286. Içme, $0.75 \mathrm{~m}$

$\mathbf{5 3 7 0} \pm 40$

3420 B.C.

$\delta C^{13}=-24.5 \%$ o

Charcoal (Populus sp.) from face of previously exposed profile at depth $0.75 \mathrm{~m}$, Mound $\mathrm{O} 55 / 1$, Nahiye of Içme. Early Bronze age (perhaps E.B. 1). Expected age: 3000-2500 B.C.

GrN-5287. Içme, $1.00 \mathrm{~m}$

$\mathbf{5 3 3 0} \pm \mathbf{4 0}$

3380 B.C.

$\delta C^{13}=-21.3 \%$

Charred grain (Triticum diococcum) from house exposed at 1.00 $m$ depth in same profile as GrN-5286, above. Early Bronze age (perhaps E.B. I). Expected age: 3000-2500 B.c.

\section{GrN-5285. Mollakendi}

$3980 \pm 70$

2030 B.C.

$\delta C^{13}=-23.8 \%$ o

Charred plant fragments from layer at depth ca. $2.00 \mathrm{~m}$ in previously exposed profile, Site O 54/2, Nahiye of Mollakendi. Early Bronze age (probably E.B. III). Expected age: 2200-2000 B.c.

General Comment: all samples pretreated with acid and alkali. Dates point to earlier beginning of Bronze Age sequence in area than hitherto assumed.

\section{Gedikli series, Turkey}

Bronze Age cremation necropolis at Gedikli Höyük near Islâhiye (37 $02^{\prime} \mathrm{N}$ Lat, $36^{\circ} 37^{\prime} \mathrm{E}$ Long), prov. of Gaziantep, SE Turkey (Alkim and Alkim, 1966). Subm. 1967 by U. B. Alkim, Istanbul, Turkey, and R. Kampman, Leiden, Netherlands.

\section{GrN-5580. Gedikli AÇ 2}

$$
\begin{aligned}
& 3990 \pm 40 \\
& 2040 \text { B. . }
\end{aligned}
$$

Charcoal from sacrificial pit in Profile 15 at $4 \mathrm{~m}$ depth. Assoc. with pottery and bones of sacrificed animal. Early Bronze III-Middle Bronze age. Expected age: 2200-2000 в.c. Coll. 1967 by H. Alkim.

\section{GrN-5581. Gedikli Km 194}

$$
\begin{gathered}
\mathbf{3 8 2 0} \pm \mathbf{4 0} \\
\mathbf{1 8 7 0} \text { B.c. } \\
\delta C^{13}=-24.2 \% 0
\end{gathered}
$$

Charcoal pieces from grave in Profile 13 at $4 \mathrm{~m}$ depth. Assoc. with bronze toggle pins and pottery. Early Bronze III-Middle Bronze age. Expected age: 2200-2000 B.c. Coll. 1967 by A. M. Dinçol. 
General Comment: both samples pretreated with acid and alkali. Age as expected.

\section{Pileh Q'aleh series, Iran}

Mound of Pileh Q'aleh, Gilan (ca. 37 $35^{\prime} \mathrm{N}$ Lat, $49^{\circ} 45^{\prime}$ E Long), $S$ of Caspian Sea, excavated 1961-62 by E. O. Negahban, Antiquities Mus., Teheran, Iran. Expected age before 12th century B.c. Subm. 1967 by R. Kampman and P. J. R. Modderman, Inst. v. Prehistorie, Leiden, Netherlands.

\section{GrN-5199. Pileh Q'aleh, Level I}

Charcoal from Level I, Trench TM.

\section{GrN-5200. Pileh Q'aleh, Level II}

Charcoal from Level II, Trench TM.

\section{GrN-5201. Pileh Q'aleh, Level VI}

Charcoal from Level VI, Trench TM.

$$
\begin{gathered}
\mathbf{3 6 2 0} \pm \mathbf{4 0} \\
\mathbf{1 6 7 0} \text { B.c. } \\
\delta C^{1 s}=-24.9 \% \text { } \\
\\
\mathbf{3 6 7 0} \pm \mathbf{4 0} \\
\mathbf{1 7 2 0} \text { B.c. } \\
\delta C^{1 s}=-24.4 \% o \\
\mathbf{3 4 4 0} \pm \mathbf{3 5} \\
\mathbf{1 4 9 0} \text { B.c. } \\
\delta C^{1 s}=-25.4 \%
\end{gathered}
$$

General Comment: all samples pretreated with acid and alkali. Compare Marlik series, below.

\section{Marlik series, Iran}

Rich royal cemetery Marlik Tepe, adjoining mound Pileh Q'aleh, above, Gilan (ca. $37^{\circ} 35^{\prime} \mathrm{N}$ Lat, $49^{\circ} 45^{\prime}$ E Long), S of Caspian Sea (Negahban, 1970). Kingdom previously unknown. Objects found suggest date 12th-9th century B.C., later than Pileh Q'aleh. Excavation 1961-2 by E. O. Negahban. Subm. 1967 by R. Kampman and P. J. R. Modderman.

\section{GrN-5198. Marlik 3}

Charcoal, mixed with soil, from Tomb XV D.

\section{GrN-5578. Marlik 5}

Bone sample from Tomb XXIII G.

\section{GrN-5577. Marlik 2}

Bone sample from Tomb XXII E.

\section{GrN-5197. Marlik 1}

Charcoal from Tomb XII E.
$3425 \pm 55$

1475 B.C.

$\delta C^{1 s}=-26.2 \%$

$2940 \pm 55$

990 B.C.

$\delta C^{13}=-19.0 \%$

$$
2940 \pm 60
$$

990 B.c.

$\delta C^{13}=-19.1 \%$

$$
860 \pm 30
$$

A.D. 1090

$\delta C^{1 s}=-23.2 \%$ 
General Comment: charcoal pretreated with acid and alkali. Collagen separated from bone samples for measurement. With exception of GrN5197, dates are as expected and suggest early stage of cemetery may be contemporary with upper level of mound Pileh Q'aleh, above.

\section{GrN-5241. Tell 'Aschtara, Syria}

$$
\begin{gathered}
2885 \pm \mathbf{3 5} \\
\mathbf{9 3 5} \text { в.c. } \\
\delta C^{13}=-24.4 \% \circ
\end{gathered}
$$

Charred grapes in storage vessel, ca. $0.60 \mathrm{~m}$ below surface in Tell 'Aschtara $\left(32^{\circ} 58^{\prime} \mathrm{N}\right.$ Lat, $36^{\circ} 8^{\prime} \mathrm{E}$ Long), $75 \mathrm{~km} \mathrm{~S}$ of Damascus, Syria, excavated 1966 by A. Abou Assaf, Dir. of Antiquities, Damascus, Syria. Expected age: 1000-500 в.c. Subm. 1967 by W. van Zeist, Biol.-Archeol. Inst., Univ. Groningen, Netherlands. Comment: pretreated with acid and alkali. Age as expected.

\section{Deir 'Alla series, Jordan}

Samples from Late Bronze and Iron age tell of Deir 'Alla $\left(32^{\circ}\right.$ $15^{\prime} \mathrm{N}$ Lat, $35^{\circ} 30^{\prime} \mathrm{E}$ Long), Jordan valley, Jordan, excavated by H. J. Franken, Univ. Leiden, Netherlands (Franken, 1969).

\section{GrN-5283. Deir 'Alla B 433a}

Charcoal from large pit, possibly a cistern, attributed to Phase $M$ before its destruction by an earthquake, dated by following sample. Coll. 1964 by H. T. Waterbolk.

\section{GrN-5633. Deir 'Alla BB 303}

$$
\begin{gathered}
2600 \pm 50 \\
\mathbf{6 5 0} \text { B.C. } \\
\delta C^{13}=-23.3 \%
\end{gathered}
$$

Charred grain in burnt layer of Phase $M$ representing destruction of temple annexes and thus also dating fragments of wall plaster painted with Aramaic texts (unpub.), found in burnt layer. Expected age: 6th century в.C. Coll. 1967 by J. D. van der Waals; subm. 1967 by H. J. Franken and collector.

\section{GrN-5634. Deir 'Alla AA 406}

$$
\begin{gathered}
2410 \pm 55 \\
\mathbf{4 6 0} \text { B.c. } \\
\delta C^{1 s}=-23.4 \% o
\end{gathered}
$$

Charred grain from small concentration in youngest burnt layer so far observed in tell. Depth $0.40 \mathrm{~m}$. Level is between Building Phases $\mathrm{N}$ and O. Assoc. with black-glazed Greek ware. Coll. 1967 by J. D. van der Waals; subm. by H. J. Franken and collector.

General Comment: all samples pretreated with acid and alkali. Dates from stratigraphically earlier layers in tell pub. in R., 1967, v. 9, p. 140. By applying correction based on dendrochronology, true age of $\mathrm{GrN}$ 5633 can be estimated at ca. 800 B.c. 


\section{Paleolithic and Mesolithic of Western Europe}

\section{Coygan series, Wales}

Coygan Cave $\left(51^{\circ} 45^{\prime} \mathrm{N}\right.$ Lat, $4^{\circ} 40^{\prime} \mathrm{W}$ Long), $25 \mathrm{~km} \mathrm{SW}$ of Carmarthen, Wales, British Isles, contained bone accumulation and Mousterian artifacts sealed by 2 calcite layers. As insufficient carbon was recovered, calcite layers were dated. Coll. and subm. 1963 by C. B. M. McBurney, Cambridge Univ., England.

\section{GrN-4399. Coygan calcrete 2, top}

Top $3 \mathrm{~cm}$ of Upper Calcrete Layer on floor of cave. Comment: outer layer removed and inner carbonate dated. $\mathrm{C}^{13}$ content indicates pure fresh water carbonate; $1300 \pm 500 \mathrm{yr}$ must probably be subtracted from result to obtain actual age (Münnich and Vogel, 1959).

\section{GrN-4423. Coygan calcite 2, bottom}

$5820 \pm 65$

3870 B.C.

$\delta C^{13}=-9.0 \%$

Bottom $2 \mathrm{~cm}$ of Upper Calcrete Layer in cave. Comment: outer layers removed with dilute acid and inner carbonate dated. $\mathrm{C}^{13}$ content indicates $1300 \pm 500$ yr should be subtracted.

\section{GrN-4400. Coygan calcrete 1}

$33,200 \pm 310$ 31,250 в.c. $\delta C^{13}=-7.4 \%$

Top $3 \mathrm{~cm}$ of Lower Calcrete Layer underlying main bone accumulation and Mousterian industry. Comment: outer layers removed and inner carbonate dated. $\mathrm{C}^{13}$ content indicates $1300 \pm 500$ yr should be subtracted. Date apparently too young, since Mousterian occurs above this layer.

\section{Toirano series, Italy}

Basura Cave at Toirano (44 $07^{\prime} \mathrm{N}$ Lat, $\left.8^{\circ} 12^{\prime} \mathrm{E} \mathrm{Long}\right), 14 \mathrm{~km} \mathrm{~N}$ of Albenga, $\mathrm{N}$ Italy, revealed Neanderthal and Cave Bear footprints when opened in 1950 (Pales, 1960). Floor contains sediment with bones, mainly cave bear, and charcoal and soot attributed to torches used by Neanderthal man. In nearby Colombo Cave Mousterian artifacts occur below Neolithic industry in sediment (Chiapella, 1958). Bone samples coll. 1966 by T. Molleson; subm. by K. P. Oakley, Brit. Mus. (Nat. Hist.), London; charcoal sample subm. previously by the late A. C. Blanc, Rome.

\section{GrN-5007. Basura charcoal}

$12,340 \pm 160$

Charcoal from floor of Basura Cave in Sala dei Misteri, apparently remains of torches used by prehistoric visitors. Comment: pretreated with acid and alkali. 
GrN-4897. Basura bone It 67

$24,230 \pm 290$

22,280 в.c.

Collagen from cave bear bones 0 to $15 \mathrm{~cm}$ below surface in Sala dei Misteri adjacent to human footprints. Comment: $4 \mathrm{~g}$ collagen extracted from $270 \mathrm{~g}$ bone for dating.

\section{GrN-5102. Basura calcite}

$5160 \pm 40$

3210 B.c.

$\delta C^{13}=-9.3 \%$

Calcite formed on bones on floor of Basura Cave. Comment: outer layers removed with dilute acid and inner carbonate dated. $\mathrm{C}^{13}$ content indicates $1300 \pm 500 \mathrm{yr}$ should be subtracted from age (Münnich and Vogel, 1959). Crust thus formed in Late Atlantic and much younger than last human occupation.

\section{GrN-5215. Colombo, calcite It 74}

$32,000 \pm 680$ 30,050 B.c. $\delta C^{13}=-1.9 \%$

Calcite cementing bones and uppermost Mousterian artifacts in Colombo cave, Layer 4. Comment: since $\mathrm{C}^{13}$ content is so high, no correction is applied to date for disequilibrium of bicarbonate solution with atmospheric $\mathrm{CO}_{2}$. Minimum date for fauna and artifacts.

General Comment: GrN-4897 suggests cave bear bones deposited until at least 24,000 yr ago and GrN-5007 suggests last humans visited cave ca. 12,000 yr ago. Latter date seems much too late for Neanderthal man, but no satisfactory explanation possible.

\section{Schnurenloch series, Switzerland}

Schnurenloch Cave, $1230 \mathrm{~m}$ alt, in Simmental near Oberwil $\left(46^{\circ}\right.$ $40^{\prime} \mathrm{N}$ Lat, $7^{\circ} 27^{\prime}$ E Long), Kreis Bern, Switzerland, excavated 1931 to 1936 by D. and A. Andrist and W. Flükiger. Below ca. $3 \mathrm{~m}$ clay and rubble ca. $1 \mathrm{~m}$ layered loam, Layers 7 a to d, produced bone of cave bear and Paleolithic stone artifacts (Andrist and Flükiger, 1962). Samples subm. 1965 by W. Flükiger.

\section{GrN-4895. Schnurenloch, grün \\ $30,020 \pm 520$ \\ 28,070 B.c. \\ $\delta C^{13}=-21.5 \%$}

Collagen from cave bear bones in Layer 7c (green loam), at ca. 2.5 to $3.5 \mathrm{~m}$ depth. Layer said to contain Late Lower (Middle?) Paleolithic artifacts of quartzite.

\section{GrN-4894. Schnurenloch, rot}

$20,100 \pm 200$

18,150 в.c.

$\delta C^{1 s}=-21.2 \%$

Collagen from cave bear bones in Layer $7 \mathrm{a}$ (red loam) at ca. 2 to $3 \mathrm{~m}$ depth. Layer contains Early Upper Paleolithic artifacts of silex.

General Comment: both samples pretreated as for unburnt bone. Similar samples measured in Bern gave: B-158: 24,000 \pm 600 for Layer $7 \mathrm{c}$ and B-157: 14,000 \pm 600 for Layer $7 \mathrm{~b}$ (unpub.). Although older than these, 
dates still young if submitter's cultural designation comparable with sequence in France. However, age of Alpine Paleolithic cultures still unknown.

\section{Ranggiloch series, Switzerland}

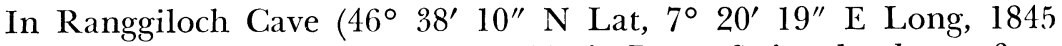
$\mathrm{m}$ alt) in Simmental, near Boltigen, Kreis Bern, Switzerland; ca. $3 \mathrm{~m}$ sediment excavated by W. Flükiger and D. Andrist between 1932 and 1946. Five layers of loam and clay with bone of cave bear, wolf, and capricorn distinguished (Andrist and Flükiger, 1962). In bottom of Layer II, 2nd from top, supposedly Paleolithic hearths found assoc. with some stone artifacts and cave bear bones. Charcoal from hearths subm. 1958 by W. Flükiger, Koppigen, and H. G. Bandi, Bernisches Hist. Mus., Bern, Switzerland.

GrN-3089. Ranggiloch 2802

$\mathbf{5 0 9 0} \pm \mathbf{5 5}$

3140 B.C.

Charcoal Sa. 2802 from Hearth b, 0.45 to $0.60 \mathrm{~m}$ depth, Sq. $79 / 80$, ca. $1 \mathrm{~m}$ inside dripline.

\section{GrN-3549. Ranggiloch 560}

$5240 \pm 100$

3290 B.c.

Charcoal Sa. 560 from Hearth a, ca. $0.55 \mathrm{~m}$ depth, Sq. 56, ca. 0.5 $\mathrm{m}$ inside dripline. Hearth a on base of loose stones.

General Comment: due to small size, samples pretreated with acid only. Another sample from Hearth b gave result B-269b: $5190 \pm 100$ (unpub.). Neolithic age of hearths thus certain and assoc. cave bear bones must have been redeposited.

\section{Abri Pataud series, France}

Additional samples from Abri Pataud ( $44^{\circ} 56^{\prime} \mathrm{N}$ Lat, $1^{\circ} 0^{\prime} \mathrm{E}$ Long) intended to clarify uncertainty in age of Couche 5, front. Coll. and subm. 1961 by H. L. Movius, Harvard Univ., Cambridge, Massachusetts.

\section{GrN-5009. Abri Pataud 5, extract}

\section{GrN-5012. Abri Pataud 5, residue}

Charred bone from Layer 5 , front, with Perigordian IV industry (Gravette points). Comment: pretreated as charred bone (R., 1963, v. 5, p. 164), highest date from 2 fractions to be preferred. Previous date for front part of Layer 5, GrN-4631: 21,780 \pm 215 thus definitely too young and layer probably contemporaneous with Layer 5, rear. For other Abri Pataud dates see R., 1967, v. 9, p. 113.
$23,350 \pm 170$ 21,400 в.с. $\delta C^{13}=-22.3 \%$

$26,050 \pm 310$ 24, 100 в.c. $\delta C^{13}=-22.4 \%$ 


\section{GrN-5499. Abri Fritseh 8d, France}

$19,280 \pm 230$

17,330 в.с.

$\delta C^{13}=-23.2 \%$

Charred bone from $2.4 \mathrm{~m}$ depth in Layer $8 \mathrm{~d}$ in Abri Fritsch, Les Roches $\left(46^{\circ} 30^{\prime} \mathrm{N}\right.$ Lat, $1^{\circ} 30^{\prime} \mathrm{E}$ Long), Pouligny-St-Pierre, Dept. Indre, France. Just above transition from Upper Solutrean to Lower Magdalenian I (Allain and Fritsch, 1967). Coll. and subm. 1967 by J. Allain, Bourges, France. Comment: pretreated as for charred bone and alkali soluble fraction measured. Oldest date thus far for beginning of Magdalenian and agrees with dates for preceding Upper Solutrean at Laugerie Haute (R., 1967, v. 9, p. 116).

\section{GrN-4677. Vilhonneur B2, residue, France}

$12,890 \pm 140$ 10,940 в.C.

GrN-4693. Vilhonneur B2, extract, France

$9490 \pm 90$

7540 B.c.

Charred bone from Layer B2 at ca. $1.3 \mathrm{~m}$ below fallen block in Abri André Ragout, Bois du Roc, Vilhonneur, near La Rochefoucauld ( $45^{\circ} 44^{\prime} \mathrm{N}$ Lat, 0.24' E Long), Charente. Layer overlies Final Solutrean and contains Early Magdalenian Industry. Coll. and subm. 1964 by L. Balout, Inst. de Paléontol. Humaine, Paris. Comment: pretreated as for charred bone and both fractions measured. Both results apparently much too young (see Abri Fritsch, above).

\section{GrN-4383. Pincevent, France}

$$
\begin{gathered}
10,760 \pm 60 \\
8810 \text { B.C. }
\end{gathered}
$$

Humic clay from ca. 1.7 to $2.0 \mathrm{~m}$ depth in Late Magdalenian open

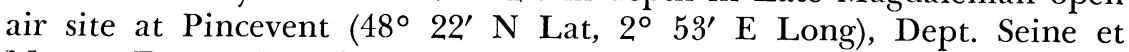
Marne, France (Leroi-Gourhan and Brezillon, 1966). Coll. and subm. 1964 by A. Leroi-Gourhan, Centre de Recherches Préhist. et Protohist., Univ. Paris. Comment: all carbonate removed with acid and rest combusted for analysis. Since presence of more recent humus must be expected, date only minimum. Compare also other dates on similar material from site: Lv-291: 10,920 \pm 540; Lv-292: 11,610 \pm 400; Lv-293: $11,310 \pm 330$ (R., 1969, v. 11, p. 108) and on charcoal: Gif-349: $9840 \pm$ 350; Gif-358: 12,300 \pm 400 (R., 1970, v. 12, p. 430). Present evidence is that Magdalenian did not last longer than Older Dryas period, i.e., 11,800 B.P.

\section{GrN-5393. Aveline's Hole, England}

$8100 \pm 50$

6150 B.C.

$\delta C^{13}=-6.3 \%$ o

Calcrete encrustation in Skull ' $O$ ' in Aveline's Hole Cave $\left(51^{\circ}\right.$ $19^{\prime} \mathrm{N}$ Lat, $02^{\circ} 45^{\prime} \mathrm{W}$ Long) on E side of Burrington Combe, Mendip Hills, Somerset, England. Skeletal remains found by Dean Buckland before 1823 in Cheddarian (Late Magdalenian) context. Subm. 1968 by K. P. Oakley, British Mus. (Nat. Hist.), London. Comment: $\mathrm{C}^{13}$ content 
indicates fresh water carbonate; $1300 \pm 500 \mathrm{yr}$ should probably be subtracted from date (Münnich and Vogel, 1959). Minimum age for skull.

\section{Meer series, Belgium}

Two open air Upper Paleolithic (Tjongerian) sites at Meirberg near Meer (51 $1^{\circ} 27^{\prime} \mathrm{N}$ Lat, $4^{\circ} 45^{\prime} \mathrm{E}$ Long), prov. of Antwerp, Belgium, excavated 1966, 1967 by F. van Noten, Mus. royale de l'Afrique centrale, Tervuren, Belgium (van Noten, 1967). Subm. 1966, 1968 by F. van Noten.

\section{GrN-4960. Meer I-1}

$$
\begin{array}{r}
\mathbf{8 9 4 0} \pm \mathbf{8 5} \\
\mathbf{6 9 9 0} \text { B.C. } \\
\delta C^{13}=-25.1 \% \circ
\end{array}
$$

Charcoal occurring as scattered fragments below sand-covered podsol profile at site Meer I, at $0.70 \mathrm{~m}$ depth and $0.30 \mathrm{~m}$ below top of podsol. Flint artifacts occur from 0.20 to $0.80 \mathrm{~m}$ below top of podsol. Coll. 1966.

\section{GrN-4961. Meer I-2}

$8950 \pm 80$ 7000 B.c.

Charcoal from same site at depth 0.85 to $1.00 \mathrm{~m}$ below surface and 0.45 to $0.60 \mathrm{~m}$ below top of podsol. Coll. 1966 .

\section{GrN-5706. Meer II-1}

Charcoal from Fireplace 2 at site Meer II, just below $B_{2 \mathrm{~h}}$ horizon of podsol profile, at 0.60 to $0.85 \mathrm{~m}$ depth. Coll. 1967.

General Comment: dates are much younger than expected Aller $\phi \mathrm{d}$ age of sites. Charcoal probably of Mesolithic age. See R., 1967, v. 9, p. 120 for other instances of later admixture of Mesolithic charcoal with Paleolithic near-surface industries.

\section{Rouffignac series, France}

Three charcoal samples from Mesolithic culture layer in cave of Rouffignac ( $45^{\circ} 3^{\prime} 11^{\prime \prime} \mathrm{N}$ Lat, $0^{\circ} 58^{\prime} 30^{\prime \prime}$ E Long) near Perigueux, France. Coll. 1960 by C. Barrière, Fac. Lettres et Sci. Humaines, Toulouse. Dates from 4 levels pub. in R., 1963, v. 5, p. 175 with incorrect level labels. These dates appear here with excavator's final numbering (from top downward).

\section{GrN-5512. Rouffignac C 2}

$$
\begin{gathered}
\mathbf{6 4 0 0} \pm \mathbf{4 0} \\
\mathbf{4 4 5 0} \text { B.c. } \\
\delta C^{13}=-25.2 \% 0
\end{gathered}
$$

Developed Tardenoisian, assoc. with human skeleton and pottery. Comment: pretreated with acid and alkali.

GrN-2889. Rouffignac C 3 


\section{GrN-2913. Rouffignac C 4 a} veterrian) in Groningen IV.

\section{GrN-2895. Rouffignac $\mathrm{C} \mathbf{4 b}$}

$8590 \pm 95$ veterrian) in Groningen IV.

\section{GrN-2880. Rouffignac C 4 c} veterrian) in Groningen IV.

\section{GrN-5513. Rouffignac C $\mathbf{5 a}$}

$$
8750 \pm 75
$$

Lower Sauveterrian, upper level. Comment: pretre and alkali.

\section{GrN-5514. Rouffignac C 5 b}

$9150 \pm 90$ 7200 в.c.

Lower Sauveterrian, lower level. Comment: pretreated with acid and alkali.

General Comment: series is very consistent. Only GrN-2880 and GrN5513 appear in the wrong order, but this may be due to statistics only (with $2 \sigma$, difference is not significant). According to excavator, pottery of Layer 2 would be of Chalcolithic age, but there were no signs of intrusions in Layer 2.

\section{Paleolithic and Mesolithic of Central and Eastern Europe}

\section{Krapina series, Yugoslavia}

In attempt to date Krapina man, K. P. Oakley arranged for samples from Zagreb Mus. Abri at Krapina $\left(46^{\circ} 10^{\prime} \mathrm{N}\right.$ Lat, $15^{\circ} 52^{\prime} \mathrm{E}$ Long), $40 \mathrm{~km} \mathrm{~N}$ of Zagreb, Croatia, excavated $1899-1905$ by D. GorjanovićKramberger, revealed 9 "layers" according to excavator's field notes (courtesy M. Malez, Zagreb) with $H$. sapiens finds in Layer 4, mainly Bos and Rhinoceros in Layers 6 and 7 higher up, and Ursus sp. in Layer 9 at top.

\section{GrN-4299. Krapina, burnt bone}

$$
30,700 \pm 750
$$

Pieces of burnt bone from mus. colln. subm. 1962 by British Mus. (Nat. Hist.), London, Some pubm. 1962 by J. S. Weimer, 263; entered in catalogue as from are bones and many pieces of cany broken and burnt burnt botreated as for burnt bone and alkali soluble fraction dated; insoluble fraction too small for measurement. Material was probably assoc. with human occupation. Date appears too young for Mousterian. 
GrN-4983. Krapina, bone

Rhinoceros bone from Layer 1-2, probably from below human finds. Subm. 1966 by J. C. Vogel and T. Molleson. Comment: outer layer removed and pretreated as for bone. $370 \mathrm{~g}$ bone gave only $0.22 \mathrm{~g}$ carbon in form of gluey "collagen". Result suggests "collagen" was mainly glue or shellac used as preservative.

General Comment: further attempts to extract collagen from bone from Layers 7 and 8 were also unsuccessful. Since dating of Krapina man on museum material is not possible and no sediments are left at Krapina site, indirect approach of dating cultural levels in nearby sites appears more feasible way to arrive at age of this important human type (see below).

\section{Velika Pećina series, Yugoslavia}

Excavation by M. Malez in Velika Pećina near Goranec $\left(46^{\circ} 17^{\prime}\right.$ $\mathrm{N}$ Lat, $16^{\circ} 02^{\prime} \mathrm{E}$ Long) on Ravna Gora, NW Croatia, $20 \mathrm{~km} \mathrm{NE}$ of Krapina, revealed 16 layers (a to p) with Roman to Mousterian cultural material. Layer c, containing Mesolithic (?) industry, is cemented with calcrete; Layers d, e contain E Gravettian (or Magdalenian ?) industry with bone points; Layers $f, g$ Aurignacian II assemblage; Layers h, i Aurignacian I assemblage with split-based bone points, and below that pre-Aurignacian and Mousterian artifacts. In top of Layer $\mathrm{j}$, human skull fragment was found (Malez and Vogel, 1970). Samples coll. by M. Malez; subm. 1966 by J. C. Vogel and T. Molleson.

\section{GrN-4979. Velika Pećina 2, Layer i}

$33,850 \pm 520$

31,900 в.c.

$\delta C^{13}=-24.2 \%$

Fine charcoal from hearth in top of Layer i at ca. $4.5 \mathrm{~m}$ depth (Aurignacian I). Comment: pretreated with acid and alkali. Date acceptable for Aurignacian. Mousterian here, and thus also at Krapina, definitely older than 34,000 B.P. Interpretation of Layer $h$ as Interstadial corresponds to dates for Denekamp Interstadial (Vogel and Zagwijn, 1967). Interstadial Layer $\mathrm{j}$ may be of Hengelo age.

\section{GrN-4980. Velika Pećina 3, Layer e}

Fine charcoal from hearth in Layer e at ca. $2.5 \mathrm{~m}$ depth (Gravettian). Comment: pretreated with acid and alkali. Oldest date thus far for post-Aurignacian industry in Yugoslavia (see Zupanov and Šjandalja, below), indicating that Aurignacian was replaced before this time.

GrN-4990. Velika Pećina 1, Layer c

White calcite crust cementing coarse deposit of Layer $\mathrm{c}$ at ca. 1.3 
$m$ depth. Comment: etched with acid; carbonate dated. $\mathrm{C}^{13}$ content indicates freshwater limestone so that $1300 \pm 500 \mathrm{yr}$ should probably be subtracted from date (Münnich and Vogel, 1959). Crust thus formed in Late Atlantic.

\section{Veternica series, Yugoslavia}

Veternica Cave lies $700 \mathrm{~m} \mathrm{~N}$ of Gornji Sterjevec, ca. $9 \mathrm{~km} \mathrm{~W}$ of Zagreb (45 $48^{\prime} \mathrm{N}$ Lat, $15^{\circ} 58^{\prime} \mathrm{E}$ Long), Croatia. Excavations in 1950 to 1955 by $M$. Malez revealed layers covering period since Last Interglacial, with abundant faunal remains. Layers a to $g$ contain traces of historic and post Mousterian man; Layers h, i, j remains of Mousterian industries, where $\mathrm{j}$ is Interglacial deposit. Portion of human skull found in Layer h. (Malez, 1965) Samples coll. by M. Malez.

\section{GrN-4984. Veternica i}

Charcoal from Layer i (Stadial) at ca. $2.6 \mathrm{~m}$ depth subm. before 1960. Comment: pretreated with acid and alkali. Agrees with other Mousterian dates in R., 1967, v. 9, p. 109-120.

\section{GrN-4989. Veternica c}

$$
\begin{gathered}
13,650 \pm 75 \\
11,700 \text { в.c. } \\
\delta C^{13}=-10.1 \% o
\end{gathered}
$$

Bottom of compact crystalline calcrete forming Layer $\mathrm{c}$ at ca. 0.5 m depth. Subm. 1966 by J. C. Vogel. Comment: outer layers etched off with acid and inner carbonate dated. $\mathrm{C}^{13}$ content indicates freshwater limestone; $1300 \pm 500$ yr should be subtracted to obtain true age (Münnich and Vogel, 1959). Layer probably of Atlantic age, apparently Late Glacial (B $\phi$ lling/Aller $\phi \mathrm{d}$ ?).

\section{GrN-4988. Romualdo Cave, Yugoslavia}

$$
\begin{array}{r}
>\mathbf{4 6 , 2 5 0} \\
\delta C^{13}=-8.7 \% \text { o }
\end{array}
$$

Crystalline calcrete layer at ca. $2.3 \mathrm{~m}$ depth (Layer f) in Romualdo Cave at top of Lim Channel near Rovinj $\left(45^{\circ} 05^{\prime} \mathrm{N}\right.$ Lat, $13^{\circ} 40^{\prime} \mathrm{E}$ Long). Istria, Yugoslavia, Layer $\mathrm{c}$ above contains bones of cave bear, etc., and E Gravettian artifacts (Malez, 1962). Calcrete thought to date interstadial. Coll. 1962 by M. Malez and subm. 1966 by J. C. Vogel and T. Molleson. Comment: outer layers of calcrete etched off with acid; inner carbonate dated. Result proves calcrete older than Hengelo Interstadial (Vogel and Zagwijn, 1967).

\section{GrN-6083. Crvena Stijena XII, Yugoslavia}

$40,770 \pm 900$

38,820 в.C. $\delta C^{13}=-20.6 \%$ o

Charcoal from Layer XII at depth $8.70 \mathrm{~m}$ in rock shelter Crvena Stijena, near Petrovići (42 ${ }^{\circ} 49^{\prime} \mathrm{N}$ Lat, $18^{\circ} 31^{\prime} \mathrm{E}$ Long), dist. Nikšić, Montenegro, Yugoslavia. Excavated strata have total depth of $11 \mathrm{~m}$. Layer I is Bronze age, II, III are Neolithic, IV Mesolithic, and V-X Upper Paleolithic. They are separated from Mousterian Layers XI-XVII by heavy fallen blocks. Layers XII-XVII attributed to Würm I period, Layers X-XI to W I/II Interstadial (Brodar, 1959). Subm. 1966 by J. C. 
Vogel and T. Molleson. Comment: date agrees well with date from Combe Grenal GrN-4304: 39,000 \pm 1500 B.P. (R., 1967, v. 9, p. 112) for sample high in Mousterian sequence, before onset of warmer condition (Hengelo Interstadial).

\section{GrN-4479. Moravany, Czechoslovakia}

Charcoal fragments from fossil soil below plough soil at nearsurface, Szeletian site of Moravany ( $48^{\circ} 35^{\prime} \mathrm{N}$ Lat, $17^{\circ} 52^{\prime} \mathrm{E}$ Long) in Waag valley near Pistyan, Slovakia. Depth 0.30 to $0.60 \mathrm{~m}$, alt. $315 \mathrm{~m}$. Coll. 1963; subm. 1964 by J. Barta, Archaeol. Inst., Slovakian Acad. Sci., Nitra. Comment: charcoal cannot be Paleolithic.

\section{Szeleta series, Hungary}

Szeleta Cave in N part of Bükk Mts. (48 $05^{\prime} \mathrm{N}$ Lat, $20^{\circ} 30^{\prime} \mathrm{E}$ Long), near town of Hámor, co. Borsoel, N Hungary, excavated by Kadič in 1915, contains Early and Main Szeletian habitation layers. Stratigraphy also described by Vértes (1959). Coll. and subm. 1965 by the late L. Vértes.

\section{GrN-6058. Szeleta 3}

$$
\begin{aligned}
& 43,000 \pm 1100 \\
& 41,050 \text { в.C. }
\end{aligned}
$$$$
\delta C^{13}=-22.0 \%
$$

Bone collagen from ca. $6 \mathrm{~m}$ below original surface in upper region of darkbrown layer (Layer 2 of Kadič) in Block B, slightly above lowest occurrence of Early Szeletian. Comment: ca. 1\% carbon as collagen extracted from bone.

\section{GrN-5130. Szeleta 2}

Bone collagen from ca. $3 \mathrm{~m}$ below original surface in lightgray layer (Layer 6 of Kadič) in Block A near cave mouth representing early to middle part of Main Szeletian deposit. Comment: $1.1 \%$ carbon as collagen extracted from bone.

General Comment: split-based bone point in Early Szeletian deposit indicates contemporaneity with Aurignacian I in nearby Istállóskö Cave, and Main Szeletian laurel leaf point in Aurignacian II layer of latter cave proves same age for these 2 phases (Vértes, 1955b; Gábori, 1960). This is confirmed by $\mathrm{C}^{14}$ dates, see Istállóskö series, below. Previous sample stratigraphically between above sample gave date GX197: $>41,700$ (unpub.).

\section{Istállóskö series, Hungary}

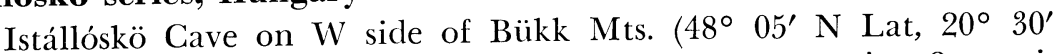
$\mathrm{E}$ Long), near town of Szilvás várad, $\mathrm{N}$ Hungary, contains 2 stratigraphically separated habitation layers (Vértes, 1955a). Upper Aurignacian II Layer already dated to ca. 31,000 (R., 1963, v. 5, p. 164). Samples of Lower Aurignacian I Layer coll. and subm. 1965 by L. Vértes. 
GrN-4659. Istállóskö 4 $0.9 \%$ carbon as collagen extracted from bone.

\section{GrN-4658. Istállóskö 3}

$39,700 \pm 900$

Bone collagen from upper level of Aurignacian I Layer containing split-based bone points. Comment: $1.2 \%$ carbon as collagen extracted from bone.

General Comment: dates prove contemporaneity of early Aurignacian in Bükk Mts. with nearby Szeletian (see above). These old dates suggest Aurignacian in E Europe much older than in W Europe, see R., 1967, v. 9, p. 109-117. According to Vértes, GrN-1501: $31,540 \pm 600$ is not from Aurignacian I Layer as stated in Groningen IV (R., 1963, v. 5, p. 165) but from Aurignacian II Layer.

\section{GrN-4950. Peskö Cave, Hungary}

$35,200 \pm 670$

33,250 в.с.

Bone collagen from lowest layer in Pesko Cave on $\delta C^{13}=-20.3 \%$ Mts $\left(48^{\circ} 05^{\prime}\right.$ Neskö Cave on S side of Bükk Mts. $\left(48^{\circ} 05^{\prime} \mathrm{N}\right.$ Lat, $20^{\circ} 30^{\prime} \mathrm{E}$ Long), N Hungary, containing Aurignacian I industry (Hermann et al., 1956; Vértes, 1959). Coll. 1966 and subm. by L. Vértes. Comment: $0.6 \%$ carbon as collagen extracted from bone. Younger than Aurignacian I dates in Istállóskö Cave (above) but still older than all dates for this industry in France.

\section{Balla Cave series, Hungary}

Balla Cave near town of Répáshuta, Bükk Mts. $\left(48^{\circ} 05^{\prime} \mathrm{N}\right.$ Lat, $20^{\circ} 30^{\prime}$ E Long), N Hungary, excavated $1909-1913$ by Hildebrand and reconsidered by Vértes (1959). In front part of cave layer with microlithic "Magdalenian" (or E. Gravettian ?) industry and child's skull, overlies base rock, while layer with Early Szeletian industry occurs in same position in back of cave. Samples coll. 1965 and subm. by L. Vértes to date Szeletian.

\section{GrN-4660. Balla Cave, charcoal}

Fine charcoal mixed with sand and bone from ca. $1 \mathrm{~m}$ depth, supposedly from Szeletian layer. Comment: all carbonate removed with repeated acid treatment and humus extracted with alkali; alkali soluble fraction measured since too little insoluble charcoal remained.

\section{GrN-4661. Balla Cave, bone}

$20,000 \pm 190$

Collagen from bones in same position as above sample. Comment: $2.2 \%$ carbon as collagen extracted from bones.

General Comment: similarity of dates suggests no considerable contamination, but they are probably too young for Szeletian and close to 
E. Gravettian date for Ságvar, GrN-1783: 18,900 \pm 100 (R., 1964, v. 6, p. 353), so that stratigraphic assignment may be wrong.

\section{GrN-5181. Samuilica Cave, Bulgaria}

$42,780 \pm 1270$

40,830 в.C.

$\delta C^{13}=-20.0 \%$

Bone collagen from $0.5 \mathrm{~m}$ depth in Upper Layer containing blade industry (Early Aurignacian?) in Samuilica Cave near village Kunina $\left(43^{\circ} 14^{\prime} \mathrm{N}\right.$ Lat, $28^{\circ} 0^{\prime}$ E Long), Vraca Malkijadol, Bulgaria. Underlying is Mousteroid-Szeletoid industry. Excavated $1955-60$ by N. Djambasov, Sofia; subm. 1966 by L. Vértes. Comment: agrees well with Early Aurignacian dates from Istállóskö, above.

\section{Mauern series, Germany}

In Cave 2 at Mauern ca. $3 \mathrm{~km} \mathrm{~N}$ of Rennertshafen $\left(48^{\circ} 46^{\prime} \mathrm{N}\right.$ Lat, $11^{\circ} 03^{\prime}$ E Long) on Danube R., Bavaria, Germany. Succession of Neolithic, Magdalenian, Altmühl and Mousterian cultural layers is present (Zotz, 1955). Samples coll. by L. F. Zotz; subm. 1957 by the late H. Gross.

\section{GrN-5000. Mauern I}

$29,410 \pm 470$ $\mathbf{2 7 , 4 6 0}$ B.c. $\delta C^{13}=-23.0 \%$

Block 1 at entrance of Cave 2 at ca. $0.7 \mathrm{~m}$ depth, assoc. with Early Magdalenian with Gravette points and primitive bone harpoons. Comment: due to small sample, only acid pretreatment. Date very old for Magdalenian and admixture of older charcoal suspected.

\section{GrN-6059. Mauern IV}

Sample from charcoal band in Layer $\mathrm{D}(=6)$ in interior of Cave 2 at $1.5 \mathrm{~m}$ depth, between Magdalenian Layer at 0.45 to $0.6 \mathrm{~m}$ and Altmühl at 2.5 to $2.95 \mathrm{~m}$ depth. Comment: pretreated with acid and alkali.

General Comment: similarity of dates suggest early Upper Paleolithic hunters visited site.

\section{Vladimir series, Russia}

Open air Upper Paleolithic site $7 \mathrm{~km} \mathrm{NE}$ of town of Vladimir $\left(56^{\circ} 08^{\prime} \mathrm{N}\right.$ Lat, $40^{\circ} 25^{\prime} \mathrm{E}$ Long), E of Moscow, USSR, excavated by O. N. Bader, shows cultural layer just above uppermost fossil soil at ca. 3.5 to $4 \mathrm{~m}$ depth. At 5 to $5.5 \mathrm{~m}$ depth another soil horizon occurs and at 9 to $10 \mathrm{~m}$ depth lies Dnieper Moraine. Coll. 1966 by O. N. Bader and V. I. Gromov; subm. 1967 by I. K. Ivanova, Geol. Inst. Acad. Sci., Moscow. 


\section{GrN-5425. Vladimir, charcoal}

Charcoal from cultural layer at ca. $3.2 \mathrm{~m}$ depth. Comment: pretreated with acid and alkali.

\section{GrN-5446. Vladimir, bone}

Collagen from bones (Rangifer tarandus) ment: $0.5 \%$ carbon as collagen dependently by H. J. Streurman.

General Comment: similarity of dates suggests valid result. Age corresponds to dates for E. Gravettian in Central Europe (R., 1967, v. 9, p. 101). For bones from same site compare GIN-14: 14,600 \pm 600 (R., 1968, v. 10, p. 422).

\section{Županov series, Yugoslavia}

In cave Županov spodmol (45 $45^{\circ} \mathrm{N}$ Lat, $14^{\circ} 06^{\prime} \mathrm{E}$ Long) near Sajevče, Postojna, Slovenia, F. Osole excavated rich Tardigravettian industry (Layer 2) similar to that of Ovčje Jama (Osole, 1963). Coll. 1966 and subm. 1967 by F. Osole, Univ. Ljubljana, Yugoslavia.

\section{GrN-5288. Županov AB, charcoal}

$$
\begin{gathered}
16,780 \pm 150 \\
14,830 \text { B.C. } \\
\delta C^{13}=-22.9 \%
\end{gathered}
$$

Charcoal from lowest Gravettian layer at ca. $0.9 \mathrm{~m}$ depth, ca. $9 \mathrm{~m}$ from cave entrance. Comment: pretreated with acid and alkali. Date slightly younger than KN-48: $19,540 \pm 500$ B.P. (unpub.) for lower Gravettian industry at Ovčja Jama.

\section{GrN-5100. Županov AB, D}

$$
\begin{aligned}
& 13,500 \pm 175 \\
& 11,550 \text { B.c. }
\end{aligned}
$$

Charcoal from higher level in Gravettian layer at ca. $0.7 \mathrm{~m}$ depth, ca. $10 \mathrm{~m}$ from cave entrance. Comment: pretreated with acid and alkali.

\section{GrN-5098.}

$$
\begin{array}{r}
12,410 \pm 70 \\
10,460 \text { B.C. } \\
\delta C^{18}=-24.3 \% \circ
\end{array}
$$

Charcoal from Late Gravettian layer at ca. $0.5 \mathrm{~m}$ depth, ca. $9 \mathrm{~m}$ from cave entrance. Comment: pretreated with acid and alkali. Date shows E. Gravettian lasted at least until B $\phi$ lling times in region. See also Šjandalja, below.

\section{Šandalja series, Yugoslavia}

In limestone quarry Šandalja, $4 \mathrm{~km} \mathrm{E}$ of Pula $\left(44^{\circ} 52^{\prime} \mathrm{N}\right.$ Lat, $13^{\circ}$ $52^{\prime}$ E Long), Istria, completely filled cave was exposed in 1962. Excavation of cave filling by M. Malez and B. Bačić revealed 8 layers (a-h) 
with fossil faunal bones and Upper Paleolithic implements. Layer b contained Late Gravettian industry with hearths and human calotte, Layer c some Gravettian, and Layers d-h artifacts attributed to Aurignacian. Layers $\mathrm{e}$ and $\mathrm{f}$ interpreted sedimentologically as interstadial (Malez, 1964; Malez and Vogel, 1969). Coll. by M. Malez; subm. 1966 by J. C. Vogel and T. Molleson.

\section{GrN-4977.}

$25,340 \pm 170$

23,390 в.c.

Collagen from bones at ca. 5 to $5.5 \mathrm{~m}$ depth in Layer $\mathrm{f}$.

\section{GrN-5013. Šandalja 3}

$23,450 \pm 180$

21,500 в.C.

Collagen from bones at ca. 4.5 to $5 \mathrm{~m}$ depth in Layer e.

$$
\delta C^{13}=-19.4 \% \text { o }
$$

\section{GrN-4978. Šandalja 1}

$12,320 \pm 100$

10,370 B.c.

$\delta C^{13}=-23.9 \%$

Charcoal from Late Gravettian hearth at ca. $2 \mathrm{~m}$ depth in Layer $\mathrm{b}$ at approx. same depth as human skull fragment. Comment: this Late Glacial industry is similar to that in Slovenia (Osole, 1963) and N Italy (Leonardi and Broglio, 1962).

\section{GrN-4976. Šandalja 5}

$$
\begin{gathered}
\mathbf{1 0 , 8 3 0} \pm \mathbf{5 0} \\
\mathbf{8 8 8 0} \text { B.c. } \\
\delta C^{13}=-19.9 \% \circ
\end{gathered}
$$

Collagen from bones at 1 to $3 \mathrm{~m}$ depth in Late Gravettian Layer b. General Comment: dates for Layer b, accumulated towards end of Last Glacial, acceptable for Late Gravettian (see also Županov, above), but those for Layers e and $\mathrm{f}$ appear very young for Aurignacian, although nothing is known about duration of this type of industry in area.

\section{GrN-5097. Kulna 6, Czechoslovakia}

$$
\begin{gathered}
11,590 \pm 80 \\
9640 \text { в.C. }
\end{gathered}
$$

Charcoal from Layer 6 , ca. $1.5 \mathrm{~m}$ deep, $39 \mathrm{~m}$ from entrance, Kủlna Cave $\left(49^{\circ} 24^{\prime} 39^{\prime \prime} \mathrm{N}\right.$ Lat, $16^{\circ} 44^{\prime} 26^{\prime \prime} \mathrm{E}$ Long) near Sloup, dist. Blansko, Moravia, Czechoslovakia. Layer 6 consists of loess with Magdalenian industry, Layer 6a, stratigraphically older loess, contains nondescript artifacts and Layer 7a, Charentian industry (late Middle Paleolithic) and Neanderthal upper jawbone (Valoch, 1967). Coll. 1966 and subm. 1967 by K. Valoch, Moravské Mus., Brno, ČSSR. Comment: only pretreated with acid. Younger than expected but acceptable for Magdalenian.

\section{Calovanie series, Poland}

Extensive excavations by R. Schild in 1963-1969 on sand dune i. and in adjacent peat bog at Calovanie in Vistula $\mathrm{R}$. valley $\left(52^{\circ} 00^{\prime} \mathrm{N}\right.$ 
Lat, $21^{\circ} 05^{\prime} \mathrm{E}$ Long), ca. $30 \mathrm{~km} \mathrm{~S}$ of Warsaw, Poland, revealed succession of Late Paleolithic and Mesolithic settlements with ample charcoal for dating. Palynologic studies by M. Dabrowski established vegetation zoning from Older Dryas to modern. Samples coll. and subm. 1966, 1967 by R. Schild, Inst. Hist. Material Culture, Warsaw, Poland.

\section{GrN-5410. Calovanie AB-1}

$$
\begin{gathered}
11,190 \pm 65 \\
9240 \text { в.с. }
\end{gathered}
$$

Charcoal from concentration in gyttja at base of Allerød peat in Tr. IX which merges into Usselo soil on adjoining sand bar. In Usselo soil, variant of evolved Epi-Magdalenian with arched, backed bladelets occurs. Coll. 1967. Comment: rootlets removed and pretreated with dilute acid and alkali. Places onset of peat formation in pine phase of Aller $\phi \mathrm{d}$, agreeing with palynologic evidence, and dates culture.

\section{GrN-5253. Calovanie LG-2}

$$
\begin{gathered}
10,820 \pm 90 \\
\mathbf{8 8 7 0} \text { B.c. } \\
\delta C^{13}=-25.4 \% 0
\end{gathered}
$$

Charcoal from thin gyttja layer on Usselo soil on slope of sand bar and contemporaneous with new Final Paleolithic industry with tanged points, Tr. VII. Coll. 1966. Comment: pretreated with acid and alkali. Places occupation at boundary Aller $\phi \mathrm{d} /$ Younger Dryas, agreeing with palynologic findings, and dates this new industry.

\section{GrN-4966. Calovanie LG-1}

$$
\begin{gathered}
10,660 \pm 100 \\
8710 \text { B.c. } \\
\delta C^{13}=-25.2 \%
\end{gathered}
$$

Charcoal from same gyttja as above, but $55 \mathrm{~m} \mathrm{~W}$ of settlement site. Coll. 1965. Comment: rootlets removed and pretreated with acid. Result confirms date of gyttja, above; contemporaneous with new industry, with tanged points, on top of Usselo soil.

\section{GrN-5255. Calovanie U I-I}

$9550 \pm 85$ 7600 B.c.

Charcoal at base of dune overlying Usselo soil, supposedly derived from latter. Coll. 1966 in Tr. VII. Comment: pretreated with acid and alkali. Date too young, admixture of Boreal-age roots thought possible.

\section{GrN-5409. Calovanie Maz II-1}

$$
\begin{gathered}
10,455 \pm 90 \\
8505 \text { в.c. } \\
\delta C^{13}=-24.7 \% \circ
\end{gathered}
$$

Charcoal from upper Mazovian cultural layer in thin gyttja fingering into dune. Coll. 1967 in Tr. IX. Comment: rootlets removed and pretreated with acid and alkali. Agrees with advanced Younger Dryas dating by palynology and acceptable for early Mazovian. 


\section{GrN-5254. Calovanie Maz I-1}

Charcoal from redeposited Mazovian cultural layer on slope of dune in Tr. III. Coll. 1965. Comment: pretreated with acid and alkali.

\section{GrN-5251. Calovanie Meso I-1}

$9250 \pm 55$ 7300 B.c.

$\delta C^{13}=-24.8 \%$

Charcoal from rewashed layer at boundary of Early Mesolithic settlement palynologically dated to Preboreal or Early Boreal. Coll. 1966 in Tr. VII. Comment: rootlets removed and pretreated with acid and alkali. Dates 1st Mesolithic occupation.

\section{GrN-5442. Calovanie Meso I-1 bis}

Same sample as above, pretreated more rigorously. Comment: after normal pretreatment, sample successively boiled in $40 \% \mathrm{NaOH}$, in chlorite solution and $72 \%$ sulphuric acid to digest rootlets. Same result indicates rootlets are not a serious source of contamination in these samples.

General Comment: dates agree well with palynologic zoning. Approx. dates for cultures at site are:
Epi-Magdalenian
9400-9000 в.C.
Mazovian
8500-8000 в.с.
Mesolithic
7300 в.c.-end Boreal.

\section{Neolithic}

\section{Poland Neolithic series, Poland}

Samples from various Neolithic sites in Poland coll. by J. A. Bakker, Inst. v. Pre- en Protohistorie, Univ. Amsterdam, Netherlands. Samples listed below have been described fully (Bakker et al., 1969; cf. also Wislański, 1970).

\section{GrN-5384. Olszanica 235.68a}

$$
\begin{array}{rl}
\mathbf{6 4 3 0} \pm \mathbf{7 5} & \mathbf{4 4 8 0} \text { B.C. } \\
\delta C^{13}=-25.24 \%
\end{array}
$$

Charcoal pieces from Fire Pit 2 in Danubian I (Linear pottery) settlement at Olszanica ( $18^{\circ} 50^{\prime} \mathrm{E}$ Long, $50^{\circ} 06^{\prime} \mathrm{N}$ Lat), prov. of Krakow, Poland. Depth ca. $0.60 \mathrm{~m}$. Pit contained one sherd of Želiezovce type and other undiagnosed sherds. Coll. 1967 by G. Johnson; subm. by S. Milisauskas, Mus. Anthropol., Univ. Michigan, Ann Arbor, Michigan. Comment: compare M-1986: $6020 \pm 220$ for Pit 1 and M-2011: $6300 \pm 400$ for Pits 1 and 6 (R., 1970, v. 12, p. 178) same site. Both pits contained Želiezovce and music note sherds. Agree with other dates from Linear pottery settlements in Central Europe. 


\section{GrN-5087. Strzelce}

Large charcoal pieces found in rubbish pit of developed Linear pottery settlement, with music note ornament, under Tumulus II (Globular Amphora culture) at Strzelce $\left(53^{\circ} 19^{\prime} \mathrm{N}\right.$ Lat, $18^{\circ} 7^{\prime} \mathrm{E}$ Long), Site 2, pow. Mogilno, woj. Bydgoszcz, Poland. Depth 1.00 to $1.50 \mathrm{~m}$. Coll. 1952 and subm. 1966 by T. Wislański, IHKM PAN, Poznan. Comment: agree with other dates from Linear pottery settlements in Central Europe.

\section{GrN-5035. Sarnowo}

$5570 \pm 60$ 3620 B.C.

$\delta C^{13}=-24.7 \%$

Finely dispersed charcoal fragments in dark pit filling under Kujavian Long Barrow 8, stratigraphically older than central grave of barrow, at Sarnowo (52 $29^{\prime} 15^{\prime \prime} \mathrm{N}$ Lat, $18^{\circ} 45^{\prime} \mathrm{E}$ Long), Site 1, pow. Wloclawek, woj. Bydgoszcz. Depth 1.20 to $1.60 \mathrm{~m}$ below top of barrow. Assoc. with sherds of Sarnowo phase (Becker A/B) of TRB culture. Barrow may be assigned to Wiórek phase, though without grave gifts (Gabalówna 1969, 1968). Coll. 1966 by L. Gabalówna, Lódz. Subm. 1966. Comment: earliest date so far for $\mathrm{A} / \mathrm{B}$ pottery; terminus post quem for barrow.

\section{GrN-5045. Radziejów}

$4710 \pm 40$

2760 B.C.

Charred grain (mainly Triticum dicoccum) at depth 1.00 to 1.50 $\mathrm{m}$ in Pit A, from Radziejów (52 $37^{\prime} 30^{\prime \prime} \mathrm{N}$ Lat, $18^{\circ} 31^{\prime} \mathrm{E}$ Long), Site 1 , pow. Radziejów Kujawski, woj. Bydgoszcz. Assoc. with amphora of TRB culture (transition between Wiórek and Luboń styles). Coll. 1961 by L. Gabalówna. Comment: compare M-1845: $4590 \pm 190$ and M-1846: 4860 \pm 200 (R., 1970, v. 12, p. 177) for same sample.

\section{GrN-5044. Zarebowo}

Charred apples from Pit II at Zarebowo, Site 1, pow. Aleksandrów Kujawski (52 $46^{\circ} \mathrm{N}$ Lat, $18^{\circ} 36^{\prime} \mathrm{E}$ Long). Depth 0.6 to $1.7 \mathrm{~m}$. Assoc. with pottery of TRB culture (transition between Wiórek and Lubon styles, cf. GrN-5045). One unornamented sherd belonged to Globular Amphora culture. In upper part of pit (later filling?) a few other cord ornamented sherds of this culture occurred. Coll. 1960 and subm. 1966 by $\mathrm{T}$. Wislański.

\section{GrN-5088. Cmielów 231}

$4615 \pm 35$

2665 B.C.

$\delta C^{13}=-24.1 \%$

Charcoal from Pit 231 at Cmielów-Gawroniec, pow. Opatów, woj. Kielce $\left(50^{\circ} 52^{\prime} \mathrm{N}\right.$ Lat, $21^{\circ} 30^{\prime} \mathrm{E}$ Long). Depth 0.8 to $1.6 \mathrm{~m}$. Assoc. with 
cultural remains of SE TRB group. Coll. 1961 by Z. Podkowińska, IHKM PAN, Warszawa. Subm. 1966.

\section{GrN-5036. Cmielów 243}

Charcoal from Pit 243, depth 0.6 to $1.5 \mathrm{~m}$. Same provenance and assoc. as $\mathrm{GrN}-5088$.

\section{GrN-5089. Cmielów 200}

Charcoal from Pit 200, depth 0.4 to $0.6 \mathrm{~m}$. Same provenance and assoc. as GrN-5088. Comment: erroneously pub. as GrN-5087 (Bakker et al., 1969).

\section{GrN-5090. Cmielow 192}

$$
\begin{gathered}
\mathbf{4 7 2 0} \pm \mathbf{4 0} \\
\mathbf{2 7 7 0} \text { в.c. } \\
\delta C^{13}=-24.3 \% \text { o }
\end{gathered}
$$

Charcoal from Pit 192, depth 0.8 to $0.9 \mathrm{~m}$. Same provenance and assoc. as GrN-5088. Comment: GrN-5036, 5088-5090 agree well with each other and with previous Heidelberg measurement H-566/592: $4675 \pm$ 110 for Pit 180, same site (unpub.).

GrN-5046. Klementowice

$4175 \pm 30$ 2220 B.c.

Bark of partly charred tree from cemetery D 1, Grave 7 at Klementowice $\left(51^{\circ} 22^{\prime} \mathrm{N}\right.$ Lat, $22^{\circ} 8^{\prime} \mathrm{E}$ Long), pow. Pulawy, woj. Lublin. Depth 0.3 to $0.5 \mathrm{~m}$. Grave goods include 3 pots and axe of Krzemionki flint, flint chips and flint objects, belonging to Wislańskis Phase II of Globular Amphora culture. Coll. 1954 and subm. 1966 by J. Kowalczyk, State Archaeol. Mus., Warsaw. Two fractions measured: volatile fraction, GrN-5046a: $4145 \pm 60$; non-volatile fraction, GrN-5046b: $4190 \pm 40$. $\delta \mathrm{C}^{13}=-25.3 \%$ and $-25.9 \%$, respectively.

General Comment: all samples pretreated with acid and alkali. Series provides a 1st outline of $\mathrm{C}^{14}$ chronology for Neolithic period in Poland. General agreement with existing archaeologic chronologies for Poland and $\mathrm{C}^{14}$ dates for related finds in adjoining countries (Bakker et al., 1969). More samples will be measured.

\section{Tirpeşti series, Roumania}

Two charcoal samples from Tîrpesti (ca. $47^{\circ} 10^{\prime} \mathrm{N}$ Lat, $26^{\circ} 20^{\prime}$ E Long), Moldavia. Subm. 1963 by E. Condurachi, Archaeol. Inst. Roumanian Acad. Sci., Bucharest, Roumania.

GrN-4424. Tirpeşti 1

Charcoal from Neolithic layer, assigned to Precucuteni III, Cucuteni $A_{1}$ en $A_{2}$ (Dumitrescu, 1963). 


\section{GrN-4425. Tirpeşti 2}

Charcoal from more recent ditch.

General Comment: both samples pretreated with acid and alkali. Date from Neolithic layer agrees with GrN-1985: $5330 \pm 80$ for Habasesti (Cucuteni $\mathrm{A}_{3}$ ) and GrN-1982: $4950 \pm 60$ for Valea Lupului (Cucuteni $\mathrm{B}_{3}$ or $\mathrm{B}_{2}$ ) (R., 1963, v. 5, p. 185). See also Berciu (1967). For further discussion of Cucuteni and Tripolje dates, see Polivanov Jar, below.

\section{GrN-5134. Polivanov-Jar, Ukrainian SSR}

$5440 \pm 70$

3490 B.C.

$$
\delta C^{13}=-22.9 \%
$$

Charcoal from lowest layer of Tripolje settlement at Polivanov Jar (ca. $48^{\circ} 30^{\prime} \mathrm{N}$ Lat, $26^{\circ} 48^{\prime} \mathrm{E}$ Long) near Komarovo, Kelmentsy Raion, Černovtsy Oblast, Ukrainian SSR. Depth not communicated. Stratigraphy of site (Passek, 1961) is: lowest layer Tripolje B1, middle layer Tripolje B2, upper layer Tripolje $\gamma 2$. Subm. by T. A. Popowa, Lvov, J. Gurba, Lublin, and J. A. Bakker, Amsterdam. Comment (J.A.B.): date agrees with other available $\mathrm{C}^{14}$ dates for Cucuteni-Tripolje culture: Bln-590: $5565 \pm 100$, end of Tripolje A with B1 elements, Novye-Rusešti (R., 1970, v. 12, p. 415); GrN-4424: $5540 \pm 85$, Precucuteni, Cucuteni Al or A2, Tîrpesti, above; GrN-1985: $5330 \pm 80$, Cucuteni A3, Habasesti (R., 1963, v. 5, p. 185); GrN-1982: $4950 \pm 60$, Cucuteni B3 or B2, Valea Lupului (R., 1963, v. 5, p. 185); Bln-631: $4870 \pm 100$, Tripolje C1, Capaevka (R., 1970, v. 12, p. 413); GrN-5088: $4615 \pm 35$, GorodskHorodistea, Tripolje C2, best of Cmielów dates, this list, for SE TRB, elsewhere assoc. to C2-Košylovce group; Bln-692: $4400 \pm 100$ and LE645: $4340 \pm 65$, Usatovo-Foltesti I, Tripolje $\gamma 2$, Majaki (R., 1970, v. 12, p. 413 and 131). Synchronization of archaeologic sequences for Tripolje (Passek) and Cucuteni (Dumitrescu) is impossible because of contradictory phase definitions, but (Dumitrescu, 1963) Tripolje A Precucuteni III, Tripolje B1 $\sim$ Cucuteni A3, Tripolje C1- $\gamma 1 \sim$ Cucuteni B1-3. Time gap between Habasesti and Valea Lupului corresponds to 5 subphases of Dumitrescu (1963). Gorodsk (Košylovce) does not seem to overlap much with earlier Tripolje phases and Usatovo, unexpectedly, seems younger; compare Bln-630: $4330 \pm 100$ for Michailovka I (R., 1970, v. 12, p. 414).

\section{GrN-5126. Majaki, Ukrainian SSR}

$3490 \pm 35$

1540 B.C.

$\delta C^{1 s}=-25.8 \%$

Charcoal from $3.5 \mathrm{~m}$ deep enclosure ditch of settlement of Late Tripolje culture (Usatovo type) at Majaki $\left(46^{\circ} 10^{\prime} \mathrm{N}\right.$ Lat, $30^{\circ} 8^{\prime} \mathrm{E}$ Long), Beljaevka Raion, Odessa Oblast, Ukrainian SSR. Depth $2.7 \mathrm{~m}$. Expected age: 2500 to 2000 B.c. Coll. 1964 by V. G. Zbenovič, Archaeol. Inst. Acad. Sci., Ukrainian SSR, Kiev; subm. by V. G. Sbenovič, J. Gurba, Lublin, and J. A. Bakker, Amsterdam. Comments: pretreated 
with acid and alkali, (J.A.B.): date apparently wrong. Part of probably same sample was dated Bln-692: $4400 \pm 100$ (R., 1970, v. 12, p. 413), which agrees with LE-645: $4340 \pm 65$ (R., 1970, v. 12, p. 131) for same site and phase. See comment on GrN-5134, Polivanov Jar, above.

\section{GrN-5125. Krivina-Golovsk, Belorussian SSR}

Charcoal from Late Neolithic culture layer (Comb-pricked ware) at Krivina near Golovsk (ca. 54 $50^{\circ} \mathrm{N}$ Lat, 29 $43^{\prime} \mathrm{E}$ Long), senno Raion, Vitebsk Oblast. Depth 1.30 to $1.45 \mathrm{~m}$. Should date arrival of corded ware culture in N Belorussia. Expected age end 3rd/beginning 2nd mill. B.c. Coll. 1966 by M. N. Černiavsky, Belorussian Acad. of Sciences, Minsk; subm. by J. Gurba, Lublin and J. A. Bakker, Amsterdam. Comment: pretreated with acid and alkali.

\section{GrN-5604. Rosdorf 240, W Germany}

$5685 \pm 75$ 3735 B.C.

$\delta C^{13}=-25.8 \%$ o

Scattered charcoal fragments in pit belonging to House II (Geleen type) of Early Linear Pottery settlement of Mühlengrun near Rosdorf (51 $1^{\circ} 31^{\prime} \mathrm{N}$ Lat, 9० $56^{\prime}$ E Long), Kreis Göttingen, W Germany (Zimmermann, 1966). Depth $0.50 \mathrm{~m}$. Coll. and subm. 1966 by W. H. Zimmermann, Seminar f. Ur- und Frühgeschichte, Göttingen. Comment: 3 samples taken together and pretreated with acid only. Compare Hv-586: $6350 \pm 70$ (R., 1967, v. 9, p. 205) for charcoal from pit of similar, possibly a little younger, house. GrN-5604 obviously ca. 600 yr too young, possibly caused by admixture of ca. $8 \%$ of recent carbon or of ca. $18 \%$ of carbon from Bronze age settlement, of which remains were found at same site (Rosdorf 38, GrN-5603: $3120 \pm 35$, below).

\section{GrN-5601. Vallon des Vaux, Switzerland}

$4930 \pm 40$

2980 B.C.

$$
\delta C^{13}=-26.0 \%
$$

Carbonized fruit (Malus) from narrow sand-filled fissure in rear of rock shelter Vallon des Vaux $\left(46^{\circ} 46.5^{\prime} \mathrm{N}\right.$ Lat, $6^{\circ} 46^{\prime} \mathrm{E}$ Long), Chavannes le Chêne, Vaud, Switzerland. Assoc. with pottery of Chasseen type (Sitterding, ms. in preparation). Depth $1.20 \mathrm{~m}$ under rock surface. Expected age: ca. 3000 B.c. Coll. 1966 by M. Sitterding; subm. 1968 by M. Villaret-von Rochow, Mus. Bot., Lausanne, Switzerland. Comment: pretreated with acid and alkali. Age as expected.

\section{GrN-5734. Seixas, Portugal}

$$
4900 \pm 40
$$
2950 B.c.

Charcoal from lowest layer in dolmen Orca de Seixas near Moimenta da Beira $\left(41^{\circ} 0^{\prime} \mathrm{N}\right.$ Lat, $7^{\circ} 43^{\prime} \mathrm{W}$ Long), prov. of Beira Alta, Portugal. Coll. 1968 by C. Raposo; subm. 1968 by V. Leisner, Deutsches Arch. Inst., Madrid, Spain. Same age expected as for Carapito I, below. Comment: pretreated with acid and alkali. 
GrN-5110. Carapito I, Portugal

Scattered charcoal fragments on original floor of chamber of dolmen Carapito I, $1.5 \mathrm{~km} \mathrm{~S}$ of village Carapito, dist. Viseu $\left(40^{\circ} 40^{\prime} \mathrm{N}\right.$ Lat, $7^{\circ} 55^{\prime} \mathrm{W}$ Long), prov. of Beira Alta, Portugal. Depth $1.50 \mathrm{~m}$ below surface of present filling of dolmen. Assoc. with purely Neolithic inventory of microliths, silex blades without retouch, polished stone objects, big callais and amphibolite beads and small chist discs (Leisner, ms. in preparation). Coll. and subm. 1966 by V. Leisner. Comment: pretreated with acid and alkali. Agrees with GrN-5734 from Seixas, above. See also dates from Frágoas GrN-4924: $5060 \pm 50$ and GrN-4925: $4610 \pm 50$ (R., 1967, v. 9, p. 132-133).

\section{GrN-5629. Bobadella, Portugal}

Charcoal from floor of supposedly undisturbed megalithic chamber (passage grave) at Orca de Bobadella ( $40^{\circ} 23^{\prime} \mathrm{N}$ Lat, $7^{\circ} 52^{\prime} \mathrm{W}$ Long), near Oliveira do Hospital, prov. of Coimbra, Portugal. Depth $1.70 \mathrm{~m}$ below barrow rim. Should date intrusion of Bell Beakers in inner part of country. Coll. 1966 by J. de Castro Nunes; subm. 1968 by V. Leisner. Comment: pretreated with acid and alkali. Date is Iron age.

\section{GrN-5628. Lapa do Bugio, Portugal}

$4850 \pm 45$ 2900 B.C.

$\delta C^{13}=-23.5 \%$

Charcoal in filling of secondary Bell Beaker grave in subterranean burial cave at Lapa do Bugio ( $38^{\circ} 38^{\prime} \mathrm{N}$ Lat, $9^{\circ} 5^{\prime} \mathrm{W}$ Long), near Sesimbra, prov. of Setubal, Portugal. Should date Bell Beaker culture at coast of Portugal. Coll. 1967 by O. de Veiga Ferreira; subm. 1968 by V. Leisner. Comment: pretreated with acid and alkali. Older than expected, but charcoal may be from original cultural layer in cave, cut through by burial.

\section{Newgrange series, Ireland}

Late Neolithic passage grave at Newgrange $\left(53^{\circ} 41^{\prime} 20^{\prime \prime} \mathrm{N}\right.$ Lat, $6^{\circ} 29^{\prime}$ W Long), co. Meath, Ireland. Excavated by O'Kelly (1964, 1968). Coll. 1963 and subm. 1967 by M. J. O’Kelly, Dept. Archaeol., Univ. College, Cork, Ireland.

\section{GrN-5462. Newgrange 1}

$4500 \pm 45$ 2550 B.C.

$\delta C^{13}=-21.0 \%$

Charcoal fragments in burnt soil used to pack and seal interstices at each end of Roof-Slab 3 in passage. Depth $2.20 \mathrm{~m}$ and $4.00 \mathrm{~m}$. 
GrN-5463. Newgrange 2

Charcoal fragments in burnt soil used to pack and seal interstices between roof-slabs at point where passage roof merges into corbelled roof of main chamber of tomb. Depth $3.30 \mathrm{~m}$ below surface of tumulus. Sample should date actual construction of tomb.

General Comment: pretreated with acid and alkali. No significant difference between dates for passage and chamber. Younger sample best date for construction of monument.

\section{GrN-5602. Vidy, Switzerland}

$4330 \pm 40$ 2380 B.C.

Wood (Abies) from Layer M (fumier lacustre) containing abraded wood fragments, carbonized Triticum dicoccum grain, seed, of Rubus idaeus, Vitis, Corylus, supposed to represent ancient shore deposit at Vidy $\left(46^{\circ} 31^{\prime} \mathrm{N}\right.$ Lat, $6^{\circ} 35^{\prime} \mathrm{E}$ Long) near Lausanne, Lake Geneva, Switzerland. Depth 2.00 to $2.50 \mathrm{~m}$. No archaeologic objects found, but pollen analysis (Villaret and Burri, 1965) favors Late Neolithic age. Coll. 1961 and subm. 1968 by M. Villaret-von Rochow, Mus. Bot., Lausanne, Switzerland. Comment: pretreated with acid and alkali. Age as expected. For dates from earlier levels at Vidy, see R., 1970, v. 12, p. 373 .

\section{Cerro de la Virgen series, Spain}

Tell at Cerro de la Virgen (ca. $37^{\circ} 40^{\prime} \mathrm{N}$ Lat, $2^{\circ} 30^{\prime} \mathrm{W}$ Long), Orce, prov. of Granada, Spain, excavated by W. Schüle 1963-1965. Subm. 1966 by W. Schüle, Göttingen, Germany.

\section{GrN-5593. Virgen 1/1963}

$$
\begin{gathered}
\mathbf{3 8 9 0} \pm \mathbf{4 0} \\
\mathbf{1 9 4 0} \text { B.c. } \\
\delta C^{13}=-24.3 \% \text {. }
\end{gathered}
$$

Charred plant remains from basal layer at $4.50 \mathrm{~m}$ depth in Bell Beaker house, possibly older than house. Early Bell Beaker culture or before.

GrN-5764. Virgen $8 / 1965$

$3800 \pm 35$

1850 B.c.

$\delta C^{13}=-25.0 \%$ o $4.00 \mathrm{~m}$.

Charred plant remains from floor of Bell Beaker house. Depth

\section{GrN-5597. Virgen $12 / 1965$}

$3920 \pm 60$

1970 в.c.

Charcoal from burnt loom at ca. $3.30 \mathrm{~m}$ depth in Bell Beaker house. Early Bell Beaker culture. 
GrN-5596. Virgen 4/1965

Charcoal from ashy cultural layer at ca. $2.00 \mathrm{~m}$ depth. Early Bell Beaker culture.

GrN-5598. Virgen $13 / 1965$

$3835 \pm 35$

1885 B.c.

$\delta C^{13}=-24.6 \%$

Charcoal and charred esparto from Bell Beaker house at ca. $2.00 \mathrm{~m}$ depth. Bell Beaker culture.

GrN-5594. Virgen 2/1963

$3735 \pm 55$

1785 B.c.

$\delta C^{13}=-24.1 \%$

Wood from shaft grave casing at ca. $3.00 \mathrm{~m}$ depth. Argar A culture.

\section{GrN-5595. Virgen $1 / 1965$}

$3865 \pm 50$

1915 B.C.

$\delta C^{13}=-22.0 \%$

Charred acorns and wood from house floor underlying Arabian layers. Some disturbance possible. Depth less than $1 \mathrm{~m}$. Argar B culture. Expected age: ca. 1500 B.c. Comment: sample dissolved completely in alkali; extract measured. Early date implies admixture with material from stratigraphically deeper strata.

General Comment: Virgen 8/1965 pretreated with acid only, rest with acid and alkali. Series dates well Bell Beaker culture in S Spain.

4. Bronze age and later

GrN-5037. Leki Male I, Poland

$3605 \pm 35$

1655 B.c.

$\delta C^{13}=-25.5 \%$

Wood from collapsed roof above double Central Grave A of Tumulus I at Leki Male (52 $09^{\prime} \mathrm{N}$ Lat, $16^{\circ} 33^{\prime}$ E Long), pow. Koscian, woj. Poznań, Poland, excavated 1953 by M. Kowiańska-Piaszykowa and S. Kurnatowski (Bakker et al., 1969). Grave goods from classic phase of Unětice culture. Depth $5.00 \mathrm{~m}$. Sample consists of only 5 to 10 tree rings but position in trunk unknown. Subm. 1966 by J. A. Bakker, Univ. Amsterdam, Netherlands. Comments: pretreated with acid and alkali; (J.A.B.): date expected, cf. Helmsdorf, Bln-248: $3613 \pm 160$ (R., 1966, v. 8, p. 29) for grave of same phase and Prasklice, Bln-475: $3845 \pm 80$ (R., 1970, v. 12, p. 406) for pit of earlier phase of same culture. Dates, in conventional $\mathrm{C}^{14}$ scale, agree well with those expected archaeologically. However, tree-ring calibration sets true age 3 to 4 centuries older.

\section{GrN-5047. Bruszczewo 53, Poland}

$3320 \pm 40$ 1370 B.c.

$\delta C^{13}=-24.6 \%$

Pieces of charcoal mainly from upper part of Pit 53 at Site 5 at 
Bruszczewo (52 2' N Lat, $16^{\circ} 35^{\prime}$ E Long), pow. Koscian, woj. Poznań, Poland; excavated by Z. Pieczyński, Muz. Archaeol., Poznań. Depth 0.20 to $0.60 \mathrm{~m}$. Assoc. with pottery, estimated later than Unnětice, but earlier than Lusatian. Coll. 1966 by J. A. Bakker; subm. by excavator and J. A. Bakker. Comment: pretreated with acid and alkali. Age as expected.

\section{Glum series, W Germany}

Two of 4 wooden disc wheels (Alnus) with inserted nave found 1880-1882 at Glum, near Wardenburg (53 $3^{\circ} 6^{\prime} \mathrm{N}$ Lat, $8^{\circ} 9^{\prime} \mathrm{E}$ Long), Landkreis Oldenburg, W Germany, below ca. $2.50 \mathrm{~m}$ Sphagnum-peat, in E part of Vehnemoor bog. Preserved in dried condition at Staatliches Mus. f. Nat. u. Vorgeschichte, Oldenburg, W Germany. Samples from near center of wheels (diam. $0.75 \mathrm{~m}$ ), tree rings not to be counted but maximum age of Alnus tree estimated at $120 \mathrm{yr}$. No assoc. finds (van der Waals, 1964). Expected age 1800-1700 B.c.: general date for start of peat formation in area. Coll. and subm. by H. Hayen, Staatliches Mus. f. Nat. u. Vorgeschichte, Oldenburg, W Germany.

\section{GrN-5419. Glum 4}

$\mathbf{3 4 4 5} \pm \mathbf{4 5}$ 1495 B.C.

GrN-5420. Glum 5

$$
\delta C^{13}=-26.1 \%
$$

$\mathbf{3 4 8 0} \pm \mathbf{4 0}$

1530 B.C.

General Comment: pretreated with acid and alkali. Indicates Early Bronze age date for wheels.

\section{GrN-5603. Rosdorf 38, W Germany}

$$
\begin{array}{r}
3120 \pm 35 \\
1170 \text { B.C. } \\
\delta C^{1 s}=-25.2 \% \text { o }
\end{array}
$$

Charcoal from pit with potsherds of unknown age (possibly Tumulus Bronze age), found during excavation of Bandkeramik settlement at Rosdorf ( $51^{\circ} 3^{\prime} \mathrm{N}$ Lat, $9^{\circ} 56^{\circ}$ E Long), Kreis Göttingen, W Germany at $1.10 \mathrm{~m}$ depth (Zimmermann, 1966). Coll. 1965 and subm. 1966 by W. H. Zimmermann, Seminar f. Ur- u. Frühgeschichte, Göttingen, W Germany. Comment: pretreated with acid only. Result proves supposition.

\section{Ipwegermoor series, W Germany}

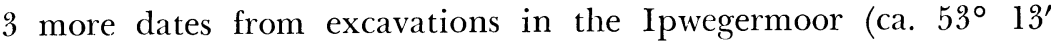
N Lat, $8^{\circ} 16^{\prime}$ E Long), near Oldenburg, Lower Saxony, W Germany, by H. Hayen, Staatliches Mus. f. Nat. u. Vorgeschichte, Oldenburg, W Germany. Dates from 10 other trackways in this bog range from 3650 2270 B.P. (see also Hayen, 1963; R., 1963, v. 5, p. 187-188; and R., 1967, v. 9, p. 141-142). Subm. by excavator.

\section{GrN-5422. Ipwegermoor LVI}

$$
\begin{array}{r}
3110 \pm 65 \\
1160 \text { B.C. } \\
\delta C^{13}=-27.5 \% o
\end{array}
$$

Wood (Alnus) from trackway ("Pfahlsteg") No. LVII, in situ at 
depth $0.50 \mathrm{~m}$ below reworked peat. Coll. 1960. Comment: pretreated with acid and alkali.

\section{GrN-5421. Wittemoor 1 and 2}

$$
\begin{gathered}
2420 \pm 95 \\
\text { 470 в.C. } \\
\delta C^{13}=-26.3 \%
\end{gathered}
$$

Near trackway XLII (53 $8^{\prime} \mathrm{N}$ Lat, $8^{\circ} 24^{\prime} \mathrm{E}$ Long) in Wittemoor near Hude, a part of Ipwegermoor, 2 unique wooden human figures (male and female) found at $1.50 \mathrm{~m}$ depth in 1965 (Hayen, 1965). Small splinters were taken near base from each of figures, and thus from core of trunk (Quercus). Breadth of figures 0.32 and $0.27 \mathrm{~m}$. Stratigraphic position indicates contemporaneity with trackway, GrN-4395: $2200 \pm$ 60 (R., 1967, v. 9, p. 142). Subm. by H. Hayen. Comment: because samples were small, they were combined and pretreated with acid only. Large error due to size.

\section{GrN-5156. Streekermoor}

$$
\begin{gathered}
1925 \pm \mathbf{3 5} \\
\text { A.D. 25 } \\
\delta C^{13}=-26.0 \% \%
\end{gathered}
$$

Charcoal from iron melting oven on sandy outcrop Iserbarg in Streekermoor. Depth $0.40 \mathrm{~m}$. No assoc. finds, but contemporaneity expected with trackways from last centuries B.c., which run in direction of ore deposit in vicinity. Coll. 1966. Comment: pretreated with acid and alkali.

General Comment: GrN-5422 within range of dates of other trackways in same bog. GrN-5421 is slightly older than trackway, but age of wood can easily bridge time difference and contemporaneity of trackway and figures considered highly probable, considering also stratigraphic evidence. GrN-5156 is somewhat younger than expected and later than any trackway dated so far in area.

\section{GrN-5250. Ivanice, Ukrainian SSR}

$3235 \pm 35$ 1285 B.c.

$$
\delta C^{13}=-24.2 \%
$$

Charcoal from pyre remains in SW quadrant in barrow of Middle Bronze age Komarowa culture at Ivanice (ca. 50 $14^{\prime} \mathrm{N}$ Lat, $25^{\circ} 40^{\prime}$ E Long), Dubno Raion, Rovne Oblast, Ukrainian SSR. Depth $1.00 \mathrm{~m}$, $1 \mathrm{~m}$ above base of $2 \mathrm{~m}$ high tumulus. Coll. 1966 by I. K. Svešnikov, Univ. Lvov, USSR; subm. 1967 by I. K. Svešnikov, J. Gurba, Lublin, and J. A. Bakker. Phase of Komarowa culture not specified by collector, but expected age (13th century B.C.) points to his Phase II (with Noua culture influences in the Dubno region, see Swiesznikow, 1967 and Sulimirski, 1968, p. 97). Comments: pretreated with acid and alkali; (J.A.B.): agrees with expectation and with GrN-5135 for Noua culture.

\section{GrN-5135. Magala, Ukrainian SSR}

$$
3100 \pm 35
$$

Charcoal in small pit below $0.90 \mathrm{~m}$ of cultural layers of Noua and Early Thracian settlement at Magala (48 $18^{\prime} \mathrm{N}$ Lat, $26^{\circ} 03^{\prime} \mathrm{E}$ Long), 
Sadgor Raion, Chernovtsy Oblast, Ukrainian SSR (Smirnova, 1957). Depth $1.1 \mathrm{~m}$. Coll. 1962 and subm. by G. I. Smirnova, Inst. Archaeol. Acad. Sci., Leningrad, J. Gurba, Lublin, and J. A. Bakker, Amsterdam. Pit thought to belong to Period IV of settlement (Early Thracian); expected age: ca. 10th century B.c. Comments: pretreated with acid and alkali; (J.A.B.): G.I.S. reconcluded after sample was dated that pit could be assigned to Noua culture represented in lowest layers of site. Charcoal from upper, Early Thracian layers of same settlement has date LE-573: $1450 \pm 90$ (R., 1970, v. 12, p. 131), which, apparently, is too recent.

\section{$\begin{array}{ll} & 2070 \pm 50 \\ \text { GrN-5133. Bolčaja Andrusovka, Ukrainian SSR } & 120 \text { B.c. }\end{array}$ \\ $\delta C^{13}=-24.2 \%$}

Charcoal taken 1959 from wall remains of sunken dwelling, from early phase of Late Bronze to Early Iron age C̆ernoles culture near Bolčaja Andrusovka (49 $10^{\prime} \mathrm{N}$ Lat, $32^{\circ} 55^{\prime}$ E Long), Georgievsk Raion, Kirowograd Oblast, Ukrainian SSR (Pokrowska and Petrowska, 1962). Depth $0.75 \mathrm{~m}$. Expected age 9th to 8th century B.c. Coll. 1959; subm. by E. F. Pokrowska, E. A. Petrowska, Archaeol. Inst. Ukrainian Acad. Sci., Kiew, J. Gurba, Lublin, and J. A. Bakker. Comment: pretreated with acid and alkali. Much younger than expected.

\section{GrN-5109. Cabezo Rodondo, Vil. 2, Spain}

\section{$3320 \pm 55$ 1370 B.c.}

$\delta C^{13}=-23.0 \%$

Upright post in house of El Argar culture, Sec. XV of Late Bronze age settlement on hill Cabezo Rodondo near Villena $\left(38^{\circ} 40^{\prime} \mathrm{N}\right.$ Lat, $0^{\circ}$ 52' W Long), prov. of Alicante, Spain. Coll. 1949 by J. M. Soler García, subm. by H. Schubart, Deutsches Archäol. Inst., Madrid. Comment: pretreated with acid and alkali. Another charcoal sample from settlement (Sec. VIII, pasillo norte below stone wall) dated at Heidelberg, H-2277-1694: $3550 \pm 55$ (Schubart, 1965). See also GrN-5594: 3735 \pm 55 from Virgen (above) for Argar culture.

\section{GrN-5568. Monte da Penha, Gui 1, Portugal}

$$
\begin{gathered}
2880 \pm 65 \\
930 \text { B.C. }
\end{gathered}
$$

Charred wooden shaft of one of pair of bronze spear-heads found by quarry workmen at depth ca. $0.50 \mathrm{~m}$ within range of Late Bronze age settlement Monte da Penha near Guimaraes $\left(41^{\circ} 27^{\prime} \mathrm{N}\right.$ Lat, $8^{\circ} 20^{\prime}$ W Long), prov. of Braga, Portugal. Expected age: 1200-400 B.c. Coll. 1967 by M. Cardozo; subm. 1968 by H. Schubart. Comment: pretreated with acid only.

\section{GrN-5108. El Cigarralejo, Cig. 2, Spain}

$$
\begin{array}{r}
2180 \pm 35 \\
230 \text { B.c. } \\
\delta C^{13}=-25.5 \% \circ
\end{array}
$$

Charcoal from very rich grave No. 200 with stone capping in cemetery of Iberian settlement and sanctuary El Cigarralejo near Mula $\left(38^{\circ} 3^{\prime} \mathrm{N}\right.$ Lat, $1^{\circ} 28^{\prime} \mathrm{W}$ Long), prov. of Murcia, Spain, excavated by 
E. Cuadrado (Schubart, 1965). Grave goods include ornaments, weapons, horse gear, imported Greek pottery, etc., providing exact historic date at beginning of 4th century B.c. Depth ca. $1.50 \mathrm{~m}$. Coll. 1963 and subm. 1964 by H. Schubart. Comment: pretreated with acid and alkali. Cf. H-2275-1683: $2160 \pm 45$ for charcoal from same grave. Both dates appear ca. 2 centuries too young. Difference too large to be explained by anomalies in original $\mathrm{C}^{14}$ activity. More probable that time lag existed between manufacturing of objects and deposition in grave.

\section{GrN-5445. Satriano Vecchio, Italy}

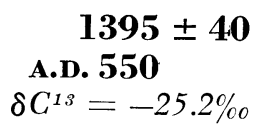

Charcoal from pottery kiln at $1.35 \mathrm{~m}$ depth in Sec. LC-TR 19 of ancient and Medieval site of Satrianum (40 34' N Lat, $15^{\circ} 35^{\prime}$ E Long), near Satriano di Lucania, prov. of Potenza (Ross Holloway, 1967). Should date from immediately before expansion of ancient town. Expected age 7th-5th century B.c. Coll. and subm. 1967 by R. Ross Holloway, Brown Univ., Archaeol. Expedition, Providence, R.I. Comment: pretreated with acid and alkali. Charcoal apparently Medieval.

\section{GrN-5086. Maiden Castle, England}

$$
\begin{gathered}
\mathbf{1 8 8 0} \pm \mathbf{3 5} \\
\text { A.D. 70 } \\
\delta C^{13}=-19.7 \%
\end{gathered}
$$

Collagen from femur of male P.12 buried in Belgici War cemetery at Maiden Castle near Dorchester (50 $40^{\circ} \mathrm{N}$ Lat, $2^{\circ} 26^{\prime} \mathrm{W}$ Long), S England, accurately dated by Roman invasion to A.D. 43. Coll. 1966 by S. Thomas; subm. 1966 by K. P. Oakley, British Mus. (Nat. Hist.), London, U.K. Comment: pretreated as for unburnt bone (Vogel, unpub.). Agrees well with historic date.

\section{GrN-5612. Alt-Bennebek 107d, W Germany \\ $1390 \pm 20$ \\ A.D. 560 \\ $\delta C^{13}=-27.4 \%$}

Wood (Quercus) from one-piece disc wheel KSB 107d found 1967 with 2 identical pieces near site of 4 more wheels, cart axe, etc., found in 1938, in peat-filled valley at Alt-Bennebek $\left(54^{\circ} 25^{\prime} \mathrm{N}\right.$ Lat, $9^{\circ} 27^{\prime}$ E Long), Kreis Schleswig, W Germany. Depth $0.80 \mathrm{~m}$. Sample from oldest tree rings from center of wheel, original diam. estimated at 0.60 m. Coll. 1967 at Schleswig-Holsteinisches Mus. f. Vor- u. Frühgeschichte, Schleswig, W Germany. Expected age: 2300-1500 в.c., based on finds of corresponding wheels in the Netherlands (see e.g. below, Ubbena, GrN-5069: $4185 \pm 60$, and van der Waals, 1964). Subm. 1967 by J. D. van der Waals, Biol.-Archaeol. Inst., Univ. Groningen, Netherlands. Comment: pretreated with acid and alkali. See also KI-26I: $1560 \pm 40$ (R., 1969, v. 11, p. 429) for sample from one of Alt-Bennebek wheels. 


\section{GrN-5038. Chodlik, small fort, Poland}

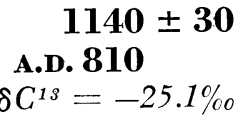

Burnt oak beam from rampart of small ringfort, $2 \mathrm{~km}$ from large ringfort near Chodlik (51 $11^{\circ} \mathrm{N}$ Lat, $21^{\circ} 55^{\prime} \mathrm{E}$ Long), pow. Opole, woj. Lublin, Poland. Depth $0.40 \mathrm{~m}$. Finds date from late 8 th to early 9th century A.D. Pottery is of type Chodlik C, which does not occur in large ringfort and should be later (Bakker et al., 1969). Coll. 1965 by S. Hoczyk and A. Gardawski, Lublin; subm. by J. A. Bakker. Comment: pretreated with acid and alkali. Date from middle rampart of large ringfort GrN-4615: $1160 \pm 50$ in Groningen VII (R., 1967, v. 9, p. 144) indeed earlier than that of small ringfort.

\section{GrN-5249. Biskupin 18, Pit V, Poland}

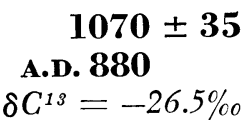

Burnt organic material from Pit $\mathrm{V}$ containing sherds of Neolithic Brzesć Kujawski Group at Biskupin, Site $18\left(52^{\circ} 47^{\prime} \mathrm{N}\right.$ Lat, $17^{\circ} 43^{\prime}$ E Long), pow. Znin, woj. Bydgoszcz, Poland. Depth 0.40 to $0.50 \mathrm{~m}$ (below disturbance). Coll. 1937 by Z. Rajewski, kept in Muz. Archeol., Poznań; subm. 1967 by T. Wislański and J. A. Bakker. Expected age: 3rd millennium B.c. Comments: pretreated with acid and alkali; (J.A.B.): much younger than expected. Several 7 th to 11 th century A.D. remains also present at site.

\section{GrN-4840. Corfu, Greece}

$175 \pm 60$

\section{A.D. 1775}

$\delta C^{13}=-25.2 \%$

Wood from Venetian chest bought on isle of Corfu $\left(39^{\circ} 40^{\prime} \mathrm{N}\right.$ Lat, $18^{\circ} 50^{\prime}$ E Long), Greece. Coll. 1963 and subm. 1966 by H. L. Visser, Scheveningen, Netherlands. Comment: pretreated with acid and alkali. True age after correction for de Vries-effect: mid-17th century; much younger than expected.

\section{GrN-4233. London bone, England}

$$
\begin{aligned}
& \quad \mathbf{3 3 0} \pm \mathbf{5 5} \\
& \text { A.D. } 1620 \\
& \delta C^{13}=-18.9 \% o
\end{aligned}
$$

Collagen from rib of human buried in A.D. 1782 in London cemetery (57 $30^{\prime} \mathrm{N}$ Lat, $0^{\circ} 10^{\prime} \mathrm{W}$ Long), England. Subm. before 1960 by K. P. Oakley. Comment: pretreated as for unburnt bone (Vogel, unpub.). Apparently, ca. $160 \mathrm{yr}$ too old.

\section{Netherlands}

\section{Paleolithic and Mesolithic}

GrN-4180. Aardhorst

$$
\begin{gathered}
11,140 \pm 70 \\
\text { 9190 B.c. } \\
\delta C^{13}=-26.2 \% o
\end{gathered}
$$

Charcoal from fireplace in Concentration III of Mesolithic surface settlement at Aardhorst near Vessem ( $51^{\circ} 25^{\prime} \mathrm{N}$ Lat, $5^{\circ} 19^{\prime} \mathrm{E}$ Long), 
prov. of Noord-Brabant. Ahrensburgian material occurs nearby. Coll. 1960, subm. 1961 by A. Bohmers. Comment: charcoal apparently Ahrensburgian. Possibility of intrusion exists.

\section{GrN-4181. Luijksgestel 224}

Charcoal from fireplace in Concentration II in Mesolithic surface settlement near Luijksgestel (5 $51^{\circ} 17^{\prime} \mathrm{N}$ Lat, $5^{\circ} 19^{\prime} \mathrm{E}$ Long), prov. of Noord-Brabant. Depth ca. $0.50 \mathrm{~m}$. Coll. and subm. 1961 by A. Bohmers. Comment: date suggests early stage of Mesolithic sequence.

\section{GrN-5043. Waskemeer-West}

$7620 \pm 50$

Excavation of Late Mesolithic surfac meer $\left(53^{\circ} 02^{\prime} \mathrm{N}\right.$ at, $6^{\circ} 15^{\prime} \mathrm{E}$. Depth $0.30 \mathrm{~m}$. A few fragmentary potsherds suggest transition to Neolithic period. Coll. and subm. 1966 by P. Houtsma, Waskemeer, Netherlands. Comment: date indicates sherds were intrusive.

GrN-4205. Tilburg $35^{a}$

$4070 \pm 85$ 2120 B.C.

Charcoal with many rootlets from near-surface fireplace in settlement of Mesolithic survival group near Tilburg $\left(51^{\circ} 33^{\prime} \mathrm{N}\right.$ Lat, $5^{\circ} 07^{\prime}$ E Long), prov. of Noord-Brabant. Subm. by A. Bohmers. Comment: charcoal apparently Late Neolithic. Remains from this period also occur.

\section{GrN-4922. Willemsstad}

$6400 \pm 85$

4450 B.c.

$\delta C^{13}=-25.3 \%$

Unique wooden statuette (van Es and Casparie, 1968), from peaty layer some $8 \mathrm{~m}$ below sea level at bottom of building trench for dock in Volkerak dam, near Willemsstad $\left(51^{\circ} 41^{\prime} \mathrm{N}\right.$ Lat, $4^{\circ} 27^{\prime} \mathrm{E}$ Long), prov. of Noord-Brabant. Coll. and subm. 1966 by W. A. van Es, State Service Archaeol. Research, Amersfoort. Mesolithic age expected. Comment: according to R. R. Newell (unpub.), Mesolithic survival groups were present in S Netherlands in 5th millennium B.c.

\section{Neolithic}

\section{Oostelijk Flevoland series, Netherlands}

Geologic, palynologic, and archaeologic studies were made in new Zuyderzee polder, Oostelijk Flevoland, by P. J. Ente, W. H. Zagwijn, and G. D. van der Heide. Under younger clay deposits a syystem of gullies, river banks, and Pleistocene river dunes occur, forming part of former lower course of river IJssel. At levels $>5 \mathrm{~m}$ below present sea level, ca. $1 \mathrm{~m}$ below former Zuyderzee bottom, Early Neolithic habitation sites were found at 7 places in ditches and borings ("Swifterbant culture"). Trial excavations made on Plots H46 and G42 (van der Heide, 1966; van der Waals, in press). A series of marine clay deposits (Calais- 
stages) were recorded in valleys and depressions, alternating with peat layers. Samples subm. by P. J. Ente, Rijksdienst v. IJsselmeerpolders, Kampen, Netherlands.

\section{GrN-5067. Swifterbant H46}

$5610 \pm 60$ 3660 B.c.

$$
\delta C^{13}=-26.9 \%
$$

Peat layer exposed in pit on Plot $\mathrm{H} 46\left(52^{\circ} 34^{\prime} \mathrm{N}\right.$ Lat, $5^{\circ} 38^{\prime} \mathrm{E}$ Long) at depth $-6.15 \mathrm{~m}$ (1.94 $\mathrm{m}$ below surface) on slope of Pleistocene river dune with human habitation, consisting of settlement pits, fireplaces, and graves. Pottery ornamentation includes vertical rows of paired finger-tip impressions, horizontal rows of vertical nail impressions, etc. Pottery differs considerably from that of Site G42. Sample dates overgrowing of dune. Date should be minimum for settlement. Coll. 1966 by P. J. Ente. Comment: pretreated with acid and cold alkali.

GrN-5443. Swifterbant G42

$5300 \pm 40$

3350 B.c.

Charcoal from dark gray humic cultural layer $(0.20 \mathrm{~m}$ thick) on Plot G42 (52 $34^{\prime} \mathrm{N}$ Lat, $5^{\circ} 35^{\prime} \mathrm{E}$ Long), on clayey river bank at -5.30 $\mathrm{m}$. Assoc. with flint tools and pottery, including such with pointed bases and rim sherds with inside ornamentation. Coll. 1967 by G. D. van der Heide. Comment: pretreated with acid and alkali.

\section{GrN-5606. Swifterbant G42 $^{\text {b }}$}

$$
\begin{gathered}
\mathbf{5 5 4 0} \pm \mathbf{6 5} \\
\mathbf{3 5 9 0} \text { B.c. } \\
\delta C^{13}=-22.6 \% \text {. }
\end{gathered}
$$

Collagen from human skeleton in 1 of 4 graves below cultural layer on Plot G42 (see GrN-5443 above). Coll. 1967 by G. D. van der Heide. Comment: pretreated as for unburnt bone.

\section{GrN-5082. Lelystad II}

$$
\begin{gathered}
6150 \pm 130 \\
4200 \text { B.C. } \\
\delta C^{13}=-26.0 \% o
\end{gathered}
$$

Basal part of peat layer between marine clay deposits at depth 4.66 to $4.71 \mathrm{~m}$ below surface on Plot A70 (52 $33^{\circ} \mathrm{N}$ Lat, $5^{\circ} 30^{\prime} \mathrm{E}$ Long). Pollen analysis points to Calais II age of lower clay and Calais III age of upper clay deposit. Expected age: 5400 B.P. Coll. 1966 in boring by P. J. Ente and W. H. Zagwijn. Comment: pretreated with acid and alkali.

\section{GrN-5081. Lelystad I}

$5330 \pm 60$

3380 B.c.

$\delta C^{1 s}=-27.2 \%$

Same sec. as Lelystad II, above. Basal part of peat layer on top of upper clay deposit. Sample taken immediately above Ulnus decline in pollen diagram. Below this decline a few Cerealia pollen occur. Expected age 4800: B.P. Coll. 1966 by P. J. Ente and W. H. Zagwijn. Comment: pretreated with acid and alkali. 
GrN-5348. Lelystad $I^{b}$, residue

GrN-5390. Lelystad $I^{b}$, extract
$5265 \pm 75$

3315 B.C.

$\delta G^{13}=-26.8 \%$

$5315 \pm 65$

3365 B.C.

$\delta C^{13}=-27.2 \%$

To check preceding date, a new core sample was taken $10 \mathrm{~m}$ away at depth 3.63 to $3.65 \mathrm{~m}$ in same sec. Coll. 1967 by P. J. Ente. Comment: pretreated with acid and cold alkali; both alkali soluble and insoluble fractions measured. Similar results indicate no contamination.

GrN-5349. Tollebeek I, residue

\section{GrN-5391. Tollebeek I, extract}

$4630 \pm 90$ 2680 B.c. $\delta C^{1 s}=-26.3 \%$

$4370 \pm 40$ 2420 B.C.

$\delta C^{13}=-27.9 \%$

Base of peat layer on marine clay deposit, representing either Calais III or IV stage, on Plot D8/9 in neighboring Noordoostpolder at Tollebeek (52 $41^{\prime} \mathrm{N}$ Lat, $5^{\circ} 41^{\prime}$ E Long). Coll. 1967 by P. J. Ente. Comment: pretreated with acid and cold alkali; both alkali soluble and insoluble fractions measured. Older date most reliable.

General Comment: dates indicate interesting possibilities for further archaeologic research and prove earlier intrusion of marine influence in area than was expected on basis of Elm decline, which seems very early in this area. Check measurements of alkali soluble fractions indicate reliability of peat dates. GrN-5443 and 5606 first dates between 5100 and 5800 B.P. for archaeologic finds in Netherlands. Contemporaneity with Rössen and Michelsberg cultures indicated.

\section{GrN-5549. Rijekholt R 9, Netherlands}

$5000 \pm 40$

3050 B.C.

$\delta C^{13}=-25.2 \%$

Charcoal from basal filling of Shaft $\mathrm{R} 9$ in flint mine, dist. Rijckholt $\left(50^{\circ} 48^{\prime} \mathrm{N}\right.$ Lat, $5^{\circ} 44^{\prime} \mathrm{E}$ Long), prov. of Limburg. Coll. 1966 by W. M. Felder and collaborators; subm. by H. T. Waterbolk. Comment: pretreated with acid and alkali. See GrN-4544: $5070 \pm 60$ (R., 1967, v. 9, p. 124) for other date from same flint mining area.

\section{Angelsloo series, Netherlands}

Three more samples were dated from Neolithic contexts in excavation at Angelsloo (52 $47^{\prime} \mathrm{N}$ Lat, $6^{\circ} 57^{\prime} \mathrm{E}$ Long), Emmen, prov. of Drenthe (Bakker and van der Waals, in press). For Bronze age dates from site see below. Subm. by J. D. van der Waals, Biol.-Archaeol. Inst. State Univ., Groningen, Netherlands. 
GrN-5103. Angelsloo 455

Scattered pieces of charcoal in settlement pit with abundant pottery of late-Drouwen stage of TRB culture. Depth 0.5 to $1.0 \mathrm{~m}$. Coll. 1965 by A. Meijer and G. Delger. Subm. 1967. Comment: pretreated with acid and alkali.

\section{GrN-5767. Angelsloo 90}

$4315 \pm 60$ 2365 B.c.

Scattered pieces of charcoal from settlement pit with pottery from last stage of TRB culture. Depth $>0.45 \mathrm{~m}$. Coll. 1961 by G. Delger and J. D. van der Waals. Subm. 1967. Comment: pretreated with acid only.

\section{GrN-5070. Angelsloo 464}

$4100 \pm 30$ 2150 B.C.

Charcoal from pyre in flat grave with cremation. Grave goods belong to last stage of TRB culture. Depth 0.4 to $0.9 \mathrm{~m}$. Coll. 1965 by J. D. van der Waals. Subm. 1967. Comment: pretreated with acid and alkali.

\section{GrN-5139. Angelsloo 535}

$2750 \pm 35$ 800 B.C.

$$
\delta C^{13}=-24.8 \% \text { o }
$$

Large charcoal pieces from concentration at 0.40 to $0.90 \mathrm{~m}$ depth in oval settlement pit with remains of TRB culture. Coll. 1966 by H. Praamstra. Comment: pretreated with acid and alkali. Charcoal apparently much younger than sherds and dating from Late Bronze age. General Comment: present series confirms dates GrN-2370: $4145 \pm 100$ (R., 1963, v. 5, p. 179) for charcoal from a flat grave and GrN-4201: $4380 \pm 75$ (R., 1967, v. 9, p. 126) for charcoal from a settlement pit. Together they suggest a duration for last (late Havelte) stage of TRB culture from ca. 4300 to 4100 B.P. For early Havelte stage there is a date GrN-1824: $4420 \pm 55$ at Anlo (R., 1963, v. 5, p. 180). In this connection GrN-5103, Angelsloo 455, from preceding late-Drouwen stage appears a little late. Further dates are needed for more precise dating of TRB cultural stages.

\section{Vlaardingen series, Netherlands}

Two more dates from Neolithic site at Vlaardingen $\left(51^{\circ} 54^{\prime} \mathrm{N}\right.$ Lat, $4^{\circ} 19^{\prime}$ E Long), prov. of Zuid-Holland. For main series, see R., 1963, v. 5, p. 177.

\section{GrN-4114. Vlaardingen N 8}

Outermost 10 tree rings of post. Coll. 1960; subm. by W. Glasbergen, Inst. v. Pre- en Protohistorie, Univ. Amsterdam, Netherlands. Comment: pretreated with acid only. Same sample as GrN-2304: 4205 \pm 75 (R., 1963, v. 5, p. 177). 


\section{GrN-4948. Vlaardingen, bone}

$4130 \pm 40$

2180 B.c.

$\delta C^{13}=-21.1 \%$

Animal bone from upper refuse layer in Neolithic creek. Subm. 1966 by W. Groenman-van Waateringe, Inst. v. Pre- en Protohistorie, Univ. Amsterdam, Netherlands. Comment: pretreated as for unburnt bone. Date agrees well with charcoal date GrN-2480: $4190 \pm 70$ for upper part of refuse layer in creek bed.

\section{GrN-5175. Hazendonk, Netherlands}

$$
\begin{gathered}
4290 \pm 40 \\
\mathbf{2 3 4 0} \text { B.c. } \\
\delta C^{13}=-27.9 \% \circ
\end{gathered}
$$

Peaty occupation layer (drill core) in clay-covered peat adjacent to Early Holocene river dune at Hazendonk ( $51^{\circ} 52^{\prime} \mathrm{N} \mathrm{Lat}, 4^{\circ} 50^{\prime} \mathrm{E}$ Long), Molenaarsgraaf, prov. of Zuid-Holland. Remains of Vlaardingen culture, various Beaker cultures, and Early Bronze age were found on dune. Depth 1.95 to $1.20 \mathrm{~m}$. Coll. 1966 and subm. 1967 by L. P. Louwe Kooijmans, Rijksmus. van Oudheden, Leiden. Sample should date active period of gully, which after being filled, became stream ridge of Schoonrewoerd, with occupation from Bell Beaker and Bronze age periods (see Molenaarsgraaf series, below). Expected age: 2400 to 2000 B.c. (Vlaardingen culture). Comment: pretreated with acid and alkali. Age as expected.

\section{GrN-5031. Voorschoten 2, Netherlands}

In addition to 4 samples from Voorschoten $\left(52^{\circ} 8^{\prime} \mathrm{N}\right.$ Lat, $4^{\circ} 25^{\prime}$ E Long) (R., 1967, v. 9, p. 125) another sample from one of basal layers, no. 4-5, with remains of early stage of Vlaardingen culture (Vl 1), was dated. Depth $1.00 \mathrm{~m}$ (Glasbergen et al., 1967). Coll. and subm. 1965 by W. H. Metz, Inst. v. Pre- en Protohistorie, Univ. Amsterdam, Netherlands. Comment: pretreated with acid only. Confirms earlier dates (e.g., GrN-4906: $4090 \pm$ 50), placing Vlaardingen culture at Voorschoten about a century later than at Vlaardingen itself (see above).

\section{GrN-2221. Zandwerven, Netherlands}

$4000 \pm 65$ 2050 в.c.

Re-excavation 1958 by Inst. v. Pre- en Protohistorie, Univ. Amsterdam, of Late Neolithic settlement, now assigned to Vlaardingen and PFB cultures, at Zandwerven (52 $41^{\prime} \mathrm{N}$ Lat, $4^{\circ} 56^{\prime} \mathrm{E}$ Long), Spanbroek, prov. of Noord-Holland (van Regteren Altena et al., 1963). Charcoal piece from pit, containing settlement refuse, with shells and fish bones. Depth ca. $0.80 \mathrm{~m}$. Comment: date later than Vlaardingen series, but contemporary with dates from Vlaardingen culture at Voorschoten (R., 1967, v. 9, p. 125 and this list, below).

\section{Leidschendam series, Netherlands}

At Leidschendam $\left(52^{\circ} 10^{\prime} \mathrm{N}\right.$ Lat, $4^{\circ} 20^{\prime} \mathrm{E}$ Long), prov. of Zuid- 
Holland, settlement of Late Neolithic Vlaardingen and PFB cultures excavated 1963 and 1964 by Inst. v. Pre- en Protohistorie, Univ. Amsterdam, Netherlands, which submitted samples 1966. Settlement occurs on narrow sand ridge. Unstratified occupation layer was $0.20 \mathrm{~m}$ thick covered by ca. $0.15 \mathrm{~m}$ peat (Glasbergen et al., 1967). Samples coll. by W. Groenman-van Waateringe.

GrN-5027. Leidschendam 23

$3660 \pm 60$

1710 B.c.

$\delta C^{13}=-30.5 \%$

Charcoal from occupation layer in Cutting 1. Coll. 1963.

GrN-5029. Leidschendam A 5

$3660 \pm 80$

1710 B.c.

$\delta C^{1 s}=-25.9 \%$

Charcoal from occupation layer in Cutting 4. Coll. 1964.

GrN-5028. Leidschendam 191

$3810 \pm 60$

1860 B.c.

$\delta C^{13}=-28.0 \%$

Charcoal from occupation layer in Cutting 4. Coll. 1964.

General Comment: due to their size, all samples pretreated with acid only. Dates a few centuries younger than upper layers at nearby Voorschoten, with which archaeologic finds are comparable. To explain difference, one would have to assume a contamination or admixture amounting to nearly $10 \%$ of recent carbon, which does not seem probable. No explanation of anomaly can be given.

\section{GrN-5069. Ubbena, Netherlands}

$4185 \pm 60$ 2235 B.C.

$\delta C^{13}=-25.3 \%$

Wood (Quercus) from one of pair of disc wheels (ritual deposit) found in small peat-filled depression near Ubbena $\left(53^{\circ} 3^{\prime} \mathrm{N}\right.$ Lat, $6^{\circ} 35^{\prime}$ E Long), Vries, prov. of Drenthe. Depth ca. $1 \mathrm{~m}$ below surface. Sample consists of outermost tree rings. Coll. 1966, subm. 1967 by J. D. van der Waals. Comment: pretreated with acid and alkali. Minimum date for dates for disc wheels in area (van der Waals, 1964).

\section{GrN-5068. Eeserveld, Netherlands}

$3955 \pm 50$

2005 B.c.

$\delta C^{13}=-24.4 \%$

Charred grain from 0.40 to $1.00 \mathrm{~m}$ depth in horse-shoe shaped pit under barrow at Eeserveld near Odoorn ( $52^{\circ} 51^{\prime} \mathrm{N}$ Lat, $6^{\circ} 51^{\prime} \mathrm{E}$ Long), prov. of Drenthe. Pit stratigraphically situated between 1st period of barrow of Late Neolithic PFB culture and secondary capping from Middle Bronze age Elp culture. Coll. 1966 and subm. 1967 by J. D. van der Waas. Comment: pretreated with acid and alkali. Minimum date for PFB grave and proves Late Neolithic age of horse-shoe shaped pit. At Schipborg, similar pit gave GrN-2445: $3780 \pm 60$ (R., 1963, v. 5, p. 182). 


\section{GrN-5295. Bornwird, Netherlands}

Sandy peat at $1.50 \mathrm{~m}$ depth overlying plough soil with Late Neolithic finds and clear traces of ploughing at Bornwird $\left(53^{\circ} 20^{\prime} \mathrm{N}\right.$ Lat, $6^{\circ} \quad 0^{\prime}$ E Long), Westdongeradeel, prov. of Friesland. Marly clay covers peat. Coll. and subm. 1967 by W. A. Casparie and W. van Zeist, Biol.Archaeol. Inst., Univ. Groningen, Netherlands. Date should be minimum for Late Neolithic occupation at site, which probably belongs to PFB culture. Comment: pretreated with acid and alkali.

\section{Molenaarsgraaf series, Netherlands}

At Molenaarsgraaf $\left(51^{\circ} 52^{\prime} \mathrm{N}\right.$ Lat, $4^{\circ} 50^{\prime} \mathrm{E}$ Long), prov. of ZuidHolland, settlement was excavated on sandy stream ridge cut through by a gully. Phase 1 of occupation is characterized by Bell Beakers of Veluwe type, Phase 2 by pottery ornamented by so-called barbed-wire stamps, Phase 3 by related but unornamented ware. Coll. 1966 and subm. 1967 by L. P. Louwe Kooijmans.

\section{GrN-5131. Molenaarsgraaf, Grave I}

Collagen from femur of 15-yr-old child in Grave I assoc. with typologically late Bell Beaker of Veluwe type. Depth $1.00 \mathrm{~m}$. Comment: pretreated as for unburnt bone.

\section{GrN-5566. Molenaarsgraaf, Grave II}

$$
\begin{array}{r}
3630 \pm 40 \\
1680 \text { B.C. } \\
\delta C^{13}=-22.6 \%
\end{array}
$$

Collagen from femur of ca. 30-yr-old male in Grave II assoc. with antler pic, 3 bone fish hooks, and 4 pieces of flint. Depth $0.80 \mathrm{~m}$. Comment: pretreated as for unburnt bone.

\section{GrN-5705. Molenaarsgraaf 210}

$$
\begin{array}{r}
3635 \pm 60 \\
1685 \text { B.c. } \\
\delta C^{13}=-27.7 \% \circ
\end{array}
$$

Large quantity of charcoal from 0.50 to $1.00 \mathrm{~m}$ depth in Pit 210 at head end of Grave II and, supposedly, contemporary with it. In pit sherd of Veluwe Bell Beaker was found. Comment: pretreated with acid and rigorously boiled with alkali.

\section{GrN-5132. Molenaarsgraaf 199}

$$
\begin{array}{r}
\mathbf{3 7 8 0} \pm \mathbf{5 5} \\
\mathbf{1 8 3 0} \text { B.C. } \\
\delta C^{13}=-27.0 \% \text {. }
\end{array}
$$

Charcoal from 0.70 to $1.00 \mathrm{~m}$ depth in Pit $\mathrm{V}$, dug shortly after Grave II. Comment: pretreated with acid and alkali.

\section{GrN-5176. Molenaarsgraaf 58}

Charcoal from 0.40 to $0.80 \mathrm{~m}$ depth in small area $\left(2 \times 2 \mathrm{~m}^{2}\right)$ of 
peat with cultural remains, including large pot, related to pottery with barbed-wire stamp ornamentation and Bentheim-type Beakers. Comment: pretreated with acid and alkali.

\section{GrN-5177. Molenaarsgraaf 29}
$3350 \pm 35$
1400 B.C.
$\delta C^{13}=-25.8 \%$

Charcoal from shallow pit with many pieces of burnt loam and pottery of Middle Bronze age character. Depth $0.40 \mathrm{~m}$. Comment: pretreated with acid and alkali.

\section{GrN-5264. Molenaarsgraaf, Trench C 8}

$2710 \pm 35$

760 B.C.

$\delta C^{13}=-28.0 \%$

Peat from $0.58 \mathrm{~m}$ depth in deposit in gully from level where all human influence on vegetation had ceased. Comment: pretreated with acid only.

General Comment: dates agree well with archaeologic estimates. GrN5132 appears a little early but charcoal is not necessarily contemporary with moment the pit was dug. Series provides good dating of late phase of Veluwe Bell Beakers at ca. 3630 B.P.

\section{GrN-4635. Haarlem, Netherlands}

$3685 \pm 40$

1735 B.c.

Thin peat layer merging into humic layer, containing sherds of Pot Beakers (Bell Beaker culture) in excavation made for construction of sewer at Schoterweg, Haarlem (52 $22^{\prime} \mathrm{N}$ Lat, $4^{\circ} 39^{\prime} \mathrm{E}$ Long). Depth 1.75 to $1.78 \mathrm{~m}$ below surface $(-1.25$ to $-1.28 \mathrm{~m})$. For general description of area see Coastal Dunes series (this list) and Jelgersma et al. (1970). Coll. 1963 by J. de Jong; subm. by W. H. Zagwijn, Geol. Dienst, Haarlem, Netherlands. Comment: pretreated with acid and alkali. First date for Pot Beakers (Lehmann, 1965) in the Netherlands, proving contemporaneity with Veluwe stage of Bell Beaker culture (see Molenaarsgraaf series, above).

\section{Bronze and Iron ages}

\section{Vaassen series, Netherlands}

Samples from excavation of a large heather-overgrown prehistoric field complex ("Celtic field") near Vaassen $\left(52^{\circ} 18^{\prime} \mathrm{N}\right.$ Lat, $5^{\circ} 56^{\prime} \mathrm{E}$ Long) Epe, prov. of Gelderland. Coll. by A. Bruin and subm. 1968 by J. A. Brongers, Rijksdienst v. het Oudheidkundig Bodemonderzoek, Amersfoort, Netherlands.

\section{GrN-5496. Vaassen 3}

$$
\begin{gathered}
\mathbf{3 5 6 0} \pm \mathbf{4 0} \\
\mathbf{1 6 1 0} \text { B.C. } \\
\delta C^{13}=-25.0 \% 0
\end{gathered}
$$

Charcoal from ca. $1 \mathrm{~m}$ depth in pit with Early Bronze age pottery ("barbed-wire" decoration), stratigraphically below arable soil of "Celtic field." Coll. 1967. 


\section{GrN-5497. Vaassen 4}

Charcoal from $0.75 \mathrm{~m}$ depth at base of light gray arable soil below bank of "Celtic field." Coll. 1968.

\section{GrN-5895. Vaassen 6}

$3020 \pm 55$

1070 B.C.

$$
\delta C^{13}=-27.0 \% \text { o }
$$

Charcoal particles at 0.70 to $0.90 \mathrm{~m}$ depth in fill of post hole of granary, preceding layer of arable soil below bank of "Celtic field" system. Granary should be Early Iron age. Coll. 1968.

GrN-5498. Vaassen 5

Charcoal from $0.40 \mathrm{~m}$ depth in cultural layer with Early Iron age pottery (Harpstedt-type) and house remains below arable soil of "Celtic field." Coll. 1967.

\section{GrN-5495. Vaassen 2}

$1800 \pm 35$

$$
\text { A.D. } 150
$$

$\delta C^{13}=-25.2 \%$

Charcoal from pit with Iron age pottery. Pit supposed to antedate “Celtic field." Depth 0.55 to 0.85 m. Coll. 1967.

\section{GrN-5494. Vaassen 1}

$$
1290 \pm 30
$$

\section{A.D. 660}

$\delta C^{13}=-25.2 \%$

Charcoal from $0.35 \mathrm{~m}$ depth in small pit dug into "Celtic field" wall. Coll. 1967.

General Comment: all samples pretreated with acid and alkali. Dates indicate Late Neolithic and Early Bronze age occupation at site. preceding the "Celtic field" which must have been in use shortly after 2420 B.P. (GrN-5498). Vaassen 2 much younger than expected, but pit may be younger than acre. GrN-5494 points to Early Medieval human activity at site.

\section{GrN-5034. Renkum, Netherlands}

$3460 \pm 40$

1510 B.C.

$$
\delta C^{13}=-24.6 \%
$$

Charcoal pieces from remains of cremation pile at base of Period II of 2-period tumulus near Renkum (51 ${ }^{\circ} 58^{\prime} \mathrm{N}$ Lat, 5 $5^{\circ} 43^{\prime} \mathrm{E}$ Long), prov. of Gelderland. Primary barrow belongs to Bell Beaker culture. Depth $0.50 \mathrm{~m}$. Coll. 1958 by A. E. van Giffen; subm. 1966 by G. Elzinga, Biol.-Archaeol. Inst., Univ. Groningen. Comment: pretreated with acid and alkali. Indicates Early Bronze age date for cremation.

\section{GrN-5350. Eersel, Netherlands}

Charcoal patch on old land surface near central grave with crema- 
tion remains in Drakenstein urn under barrow with ditch and bank at Eersel (51 $22^{\prime} \mathrm{N}$ Lat, $5^{\circ} 19^{\prime} \mathrm{E}$ Long), prov. of Noord-Brabant (van Zeist, 1967). Depth 0.65 to $0.70 \mathrm{~m}$. Coll. 1966 and subm. 1967 by J. F. van Regteren Altena, Rijksdienst v. het Oudheidkundig Bodemonderzoek, Amersfoort. Comment: pretreated with acid and alkali. Agrees with dates from similar monuments at Toterfout-Halve Mijl, see GrN1828: $3420 \pm 45$ (R., 1963, v. 5, p. 188).

\section{Angelsloo-Emmerhout series, Netherlands}

From 1964 to 1968 a large Bronze age settlement was excavated in contiguous suburbs Angelsloo and Emmerhout (52 47' $\mathrm{N}$ Lat, $6^{\circ}$ $56^{\prime}$ E Long) of Emmen, prov. of Drenthe (Butler, 1969). Occupation traces consisted of post holes, forming plans of long houses and pits of various kinds. Widely spaced houses made order difficult to establish. Barrows and urnfields interspersed with settlement remains. Neolithic remains also present (see Angelsloo series above). Subm. by J. D. van der Waals, Univ. Groningen, Netherlands.

\section{GrN-5183. Angelsloo 163}

$$
\begin{gathered}
\mathbf{3 4 0 5} \pm \mathbf{3 5} \\
\text { 1455 B.c. } \\
\delta C^{13}=-25.2 \% \circ
\end{gathered}
$$

Scattered charcoal pieces at $0.93 \mathrm{~m}$ depth in filling of tangential secondary grave in Barrow 8 of Middle Bronze age Elp culture. Coll. 1965 by A. Meijer and G. Delger.

\section{GrN-5184. Angelsloo 338 \\ 1060 B.C. \\ $\delta C^{13}=-25.5 \%$}

$3010 \pm 40$

Charcoal from concentrations in filling of tangential secondary grave in Barrow 9 of Middle Bronze age Elp culture. Depth 0.17 to $0.20 \mathrm{~m}$ below present surface; original depth unknown; barrow was destroyed. Coll. 1965 by A. Meijer and G. Delger.

\section{GrN-5187. Angelsloo 31 \\ $3485 \pm 35$ \\ 1525 B.c. \\ $\delta C^{13}=-25.5 \%$}

Charcoal pieces at $0.70 \mathrm{~m}$ depth from $1 \mathrm{~m}$ deep circular settlement pit. Assoc. with Early Bronze age pottery, with so-called barbed-wire decoration. Pit adjacent to House 1. Coll. 1964 by H. Praamstra.

\section{GrN-5186. Angelsloo 39}

$$
\begin{gathered}
\mathbf{2 8 3 0} \pm \mathbf{3 5} \\
\mathbf{8 8 0} \text { B.c. } \\
\delta C^{1 s}=-26.7 \% \circ
\end{gathered}
$$

Charcoal pieces at $0.50 \mathrm{~m}$ depth from $0.80 \mathrm{~m}$ deep circular settlement pit (depth $0.80 \mathrm{~m}$ ), adjacent to House 1. Early and Middle Bronze age pottery in immediate vicinity. Coll. 1964 by H. Praamstra. 


\section{GrN-5185. Angelsloo 418}

Charcoal pieces from 0.40 to $0.50 \mathrm{~m}$ depth in post hole of House 1 . Coll. 1965 by J. D. van der Waals.

\section{GrN-5105. Angelsloo 235}

$2910 \pm 35$

960 в.c.

Charcoal pieces from 0.40 to $1.00 \mathrm{~m}$ depth in irregular pit complex with Middle or Late Bronze age pottery adjacent to House 7. Coll. 1965 by A. Meijer and G. Delger.

\section{GrN-5265. Angelsloo 84}

Charred grain, mainly hulled barley, further naked barley and emmer wheat, from isolated pit without diagnostic finds. In Netherlands hulled barley replaces naked barley in Early Iron age. Should permit more precise dating of transition. Coll. 1964. Subm. by W. van Zeist. Comment: see also GrN-5266, Elp, below.

\section{GrN-5588. Emmerhout 215}

$$
\begin{gathered}
\mathbf{3 3 2 0} \pm \mathbf{6 0} \\
\mathbf{1 3 7 0} \text { B.c. } \\
\delta C^{13}=-24.0 \% \text { o }
\end{gathered}
$$

Charred grain at 0.40 to $0.90 \mathrm{~m}$ depth from pit in House 7 . Both Early Bronze age and TRB pottery occur in vicinity. House plan differs considerably from that of most Bronze age houses in Angelsloo and Emmerhout (Elp type). Coll. 1968 by S. Bottema; subm. by J. D. van der Waals and W. van Zeist.

\section{GrN-5862. Emmerhout 26}

$2890 \pm 35$

940 B.C.

$\delta C^{13}=-25.5 \%$

Charcoal pieces at 0.65 to $0.85 \mathrm{~m}$ depth from fireplace depression in center of Elp type House 1. A Late Bronze age or Early Iron age sand dune covers house. Coll. 1966 by A. Meijer and G. Delger.

\section{GrN-5861. Emmerhout 304}

$2905 \pm 35$

955 B.C.

$$
\delta C^{1 s}=-26.0 \%
$$

Small charcoal pieces from pit filling in central aisle of Elp type House 2. Coll. 1967 by S. Bottema.

\section{GrN-5777. Emmerhout 308}

$$
2895 \pm 35
$$

945 B.C.

Scattered charcoal pieces from another pit in Elp type House 2 Coll. 1967 by S. Bottema. 


\section{GrN-5776. Emmerhout 135}

Charcoal pieces at ca. $0.70 \mathrm{~m}$ depth from fireplace depression in central aisle of Elp type House 5. Coll. 1967 by G. Delger and A. Meijer.

\section{GrN-5775. Emmerhout 267}

$3090 \pm 60$

1140 B.c.

$\delta C^{13}=-25.9 \%$

Charcoal at 0.80 to $1.00 \mathrm{~m}$ depth from small fire pit in side aisle of House 13, which, because of cattle stall boxes, was expected to be younger than other houses. Coll. 1967 by G. Delger and A. Meijer.

General Comment: Samples 31, 39, 215, 135, and 267 pretreated with acid only, rest pretreated with acid and alkali. GrN-5183 is older than expected. Early Bronze age habitation proved by GrN-5187, though not dating adjacent House 1 (see GrN-5185) and by GrN-5588, possibly dating new house type. Most houses appear to date from Middle Bronze age; dates range from $3090 \pm 60$ (GrN-5776) to $2830 \pm 35$ (GrN-5186). Grain sample GrN-5265 proves later habitation at site, which is also archaeologically evident.

\section{Zijderveld series, Netherlands}

Excavation of prehistoric settlement and adjacent gully deposits in river marsh area near Zijderveld (51 $57^{\prime} \mathrm{N}$ Lat, $5^{\circ} 09^{\prime} \mathrm{E}$ Long), prov. of Zuid-Holland. Habitation remains, houses, fences, etc., from Middle Bronze age Hilversum culture and from Early pre-Roman Iron age. Cultural layers separated only locally. Medieval clay covers settlement. Subm. 1967 by J. F. van Regteren Altena.

\section{GrN-5376. Zijderveld B}

Outermost tree rings of post stump in post hole of Middle Bronze age round house. Coll. 1965 by R. S. Hulst. Depth $1.56 \mathrm{~m}$.

\section{GrN-5574. Zijderveld D}

$$
\begin{gathered}
2665 \pm 80 \\
715 \text { B.c. } \\
\delta C^{1 s}=-31.0 \% o
\end{gathered}
$$

Stump of small post from wattle and daub wall of Iron age rectangular house. Depth 0.75 to $0.90 \mathrm{~m}$. Coll. 1966 by R. S. Hulst.

\section{GrN-5351. Zijderveld E}

$$
\begin{gathered}
2565 \pm 100 \\
\text { 665 B.c. } \\
\delta C^{13}=-27.1 \% o
\end{gathered}
$$

Stump of Iron age granary post at 0.80 to $1.00 \mathrm{~m}$ depth. Coll. 1966 by R. S. Hulst. 
GrN-5573. Zijderveld C

$$
\begin{gathered}
2390 \pm 65 \\
450 \text { B.C. } \\
\delta C^{13}=-27.9 \% \%
\end{gathered}
$$

Base of roof-bearing post of Iron age house. Sample taken between 10 th and 20th tree ring from outside. Depth 0.75 to $1.00 \mathrm{~m}$. Coll. 1966 by R. S. Hulst.

\section{GrN-5352. Zijderveld F}

$2150 \pm 90$

200 B.C.

$\delta C^{13}=-26.8 \%$

Twigs from trackway at $1.65 \mathrm{~m}$ depth. Expected age either Bronze age or Iron age. Subm. 1965 by R. S. Hulst.

\section{GrN-5221. Zijderveld II/2}

$4620 \pm 60$

2670 B.c.

Gyttja-containing peat intercalation at 1.20 to $1.28 \mathrm{~m}$ depth, clay deposits of gully adjacent to settlement. No indication yet of human influence on vegetation at this depth in pollen diagram. Coll. 1965 by J. de Jong.

\section{GrN-5220. Zijderveld II/1} II/2. High Came Sec. II as Zijderveld . High Cerealia values in pollen diagram indicate contemporaneity with Middle Bronze age settlement. Coll. 1965 by J. de Jong.

\section{GrN-5219. Zijderveld I/3}

$$
\begin{gathered}
2880 \pm \mathbf{3 5} \\
\mathbf{9 3 0} \text { B.C. } \\
\delta C^{13}=-27.9 \% \circ
\end{gathered}
$$

Base of lower peat deposit in Sec. I, stratigraphically above clay deposit of Sample II/1. Depth 1.14 to $1.19 \mathrm{~m}$. Coll. 1965 by J. de Jong.

\section{GrN-5218. Zijderveld I/1}

Base of upper peat deposit in Sec. I. Early Sub-Atlantic.

310 B.C.

$\delta C^{13}=-27.4 \%$

General Comment: Zijderveld B pretreated with acid only, rest pretreated with acid and alkali. Dates from settlement as expected, GrN5352, which dates occupation of area at Late pre-Roman Iron age. Dates of highly differentiated gully deposits help to establish correlation of sedimentary phases with stages of human habitation. Pollen evidence from Sec. II suggests habitation prior to Middle Bronze age (shortly after GrN-5221: $4620 \pm 60$ ); no archaeologic evidence yet. Bronze age remains mentioned by Beex and Hulst (1968).

\section{Putten series, Netherlands}

Excavation of heavily damaged prehistoric barrow at Putten $\left(52^{\circ}\right.$ $15^{\prime} \mathrm{N}$ Lat, $5^{\circ} 48^{\prime} \mathrm{E}$ Long), prov. of Gelderland. Subm. 1965 by R. S. 
Hulst, Rijksdienst v. het Oudheidkundig Bodemonderzoek, Amersfoort, Netherlands.

GrN-4957. Putten 45

Charcoal pieces at ca. $1.75 \mathrm{~m}$ depth from post hole in single widely spaced timber circle belonging to Period 3 of barrow. Coll. 1965 by submitter. Comment: pretreated with acid only.

GrN-4958. Putten 10

$3060 \pm 35$ 1110 B.C.

Charcoal from secondary grave (Brandskelettgrab). Later than Period 2 (and also Period 3?). Coll. 1964 by submitter. Comment: pretreated with acid and alkali.

General Comment: ages as expected.

\section{GrN-5266. Elp 98, Netherlands}

$3105 \pm 65$ 1155 B.C.

Charred grain, mainly emmer wheat and naked barley, some hulled barley, from settlement pit at Elp $\left(52^{\circ} 54^{\prime} \mathrm{N}\right.$ Lat, $6^{\circ} 38^{\prime} \mathrm{E}$ Long), Westerbork, prov. of Drenthe (Waterbolk, 1964). Other dates from same settlement in R., 1967, v. 9, p. 134. Sample subm. 1967 by W. van Zeist to obtain more accurate date for replacement of naked barley by hulled variety (van Zeist, 1971). Comment: pretreated with acid and alkali. GrN-5266 (Elp 98), GrN-1553 and GrN-2392 (Gees, mean value $2420 \pm 35$; R., 1963 , v. 5, p. 193, hulled barley with some emmer wheat) and GrN-5265 (Angelsloo 84, this list) suggest that N Netherlands naked barley was replaced by hulled variety in Early Iron age.

\section{GrN-5356. Benschop, Netherlands}

$2960 \pm 60$

1010 B.C.

Charcoal from concentration in clay covered cultural layer with small pottery fragments of supposed Late Neolithic character at Benschop $\left(52^{\circ} 0^{\prime} \mathrm{N}\right.$ Lat, $4^{\circ} 59^{\prime} \mathrm{E}$ Long), prov. of Utrecht. Depth 0.60 to $0.80 \mathrm{~m}$. Coll. and subm. 1967 by L. P. Louwe Kooijmans. Comment: pretreated with acid and alkali. Date later than expected but within period of dense human habitation.

\section{GrN-5357. Biesheuvel, Netherlands}

$$
\begin{gathered}
\mathbf{3 1 2 5} \pm \mathbf{4 0} \\
1175 \text { B.c. } \\
\delta C^{13}=-26.0 \% 0
\end{gathered}
$$

Scattered charcoal pieces at 0.60 to $0.95 \mathrm{~m}$ depth in small pit with pottery of supposed Late Neolithic character on stream ridge near Biesheuvel (51 $55^{\circ} \mathrm{N}$ Lat, $5^{\circ} 4^{\prime} \mathrm{E}$ Long), mun. of Wijk en Aalburg, prov. of Noord-Brabant. Coll. and subm. 1967 by L. P. Louwe Kooijmans. Comment: pretreated with acid and alkali. Date later than expected but within period of dense human habitation. 


\section{Wychen series, Netherlands}

Sandy peat layer at 1.68 to $2.00 \mathrm{~m}$ depth (lake bottom?) with supposedly Iron age potsherds under sand dune at de Pas, near Wychen $\left(51^{\circ} 48^{\prime} \mathrm{N}\right.$ Lat, $5^{\circ} 44^{\prime} \mathrm{E}$ Long), prov. of Gelderland. Coll. and subm. 1967 by D. Teunissen, Geol. Afdeling, Univ. Nijmegen, Netherlands.

\section{GrN-5482. Wychen 511}

Sandy peat at 1.90 to $1.93 \mathrm{~m}$ depth.

$$
\begin{array}{r}
\mathbf{3 4 8 0} \pm \mathbf{4 0} \\
1530 \text { B.C. } \\
\delta C^{13}=-28.5 \% \text { o }
\end{array}
$$

\section{GrN-5481. Wychen 510}

Sandy peat at 1.70 to $1.73 \mathrm{~m}$ depth.

General Comment: both samples pretreated with acid and alkali. Peat dates from Bronze age. Late Bronze age sand dunes are known from various places in Netherlands (Waterbolk, 1962).

\section{GrN-5217. Alkmaar-de Heul, Netherlands}

$$
\begin{array}{r}
\mathbf{3 1 4 0} \pm 50 \\
1190 \text { B.c. } \\
\delta C^{13}=-28.1 \% \circ
\end{array}
$$

Base of peat layer of $0.50 \mathrm{~m}$ thickness, intercalated between sand deposits at de Heul, near Alkmaar (52 $38^{\prime} \mathrm{N}$ Lat, $4^{\circ} 45^{\prime} \mathrm{E}$ Long), prov. of Noord-Holland. Depth 1.40 to $1.44 \mathrm{~m}$ below surface. Peat contains archaeologic remains of probable Early Iron age. Coll. 1964 by J. de Jong; subm. by J. F. van Regteren Altena. Comment: pretreated with acid and alkali. Age as expected.

\section{Hoogkarspel series, Netherlands}

Barrows and settlement from Late Bronze age were excavated in 1965 at Hoogkarspel $\left(52^{\circ} 4^{\prime} \mathrm{N}\right.$ Lat, $5^{\circ} 10^{\prime} \mathrm{E}$ Long), prov. of NoordHolland, by J. A. Bakker, Inst. v. Pre- en Protohistorie, Amsterdam, Netherlands (Bakker and Brandt, 1966). Subm. by excavator.

\section{GrN-5050. Hoogkarspel 1}

$$
\begin{gathered}
3020 \pm 40 \\
1070 \text { в.C. } \\
\delta C^{1 s}=-24.9 \%
\end{gathered}
$$

Big lumps of charcoal from secondary grave with human cremation in Tumulus II, Sq. H 19, depth $0.70 \mathrm{~m}$. Coll. by W. J. Manssen.

\section{GrN-5051. Hoogkarspel 2}

$$
2680 \pm 50
$$

$$
\delta C^{13}=-26.2 \%
$$

Charcoal fragments from layer in ring ditch of Tumulus II, Sq. M 14, depth 0.45 m. Coll. by J. A. Bakker. 
GrN-5048. Hoogkarspel 4

Charcoal and ash from settlement ditch, which cuts through ring ditch of Barrow II, Sq. M 19, depth 1.00 m. Coll. by R. W. Brandt.

\section{GrN-5030. Hoogkarspel 5}

$2235 \pm 60$

285 B.c.

$\delta C^{13}=-26.0 \%$

Black soil with some charcoal from ditch with rich settlement remains from late stage of settlement. Sq. Y 8, depth ca. $1.00 \mathrm{~m}$. Coll. by J. A. Bakker.

General Comment: all samples pretreated with acid and alkali. Date for barrow agrees with other dates for Bronze age barrows in area, see Oostwoud and Wervershoof (R., 1963, v. 5, p. 191). GrN-5051 and $\mathrm{GrN}-5048$ are acceptable dates for settlement. GrN-5030 appears too young, which may be due to bad quality of sample.

\section{GrN-4959. Berghem II ${ }^{8}$, Netherlands}

$2630 \pm 65$

680 B.C.

$\delta C^{13}=-27.5 \%$

Scattered charcoal fragments from filling of oval ditch below Tumulus II at Berghem ( $51^{\circ} 45^{\prime} \mathrm{N}$ Lat, $5^{\circ} 35^{\prime} \mathrm{E}$ Long), prov. of NoordBrabant. Depth $0.60 \mathrm{~m}$. Early Iron age date expected for this burial type. Coll. 1965 and subm. 1966 by G. J. Verwers, Inst. v. Prehistorie, Univ. Leiden, Netherlands. Comment: pretreated with acid and alkali. Age as expected.

\section{Culemborg series, Netherlands}

Excavation in 1966 of Early Iron age settlement in river marsh area near Culemborg ( $51^{\circ} 57^{\prime} \mathrm{N}$ Lat, $5^{\circ} 13^{\prime} \mathrm{E}$ Long), prov. of Gelderland. Coll. and subm. 1966 by L. P. Louwe Kooijmans.

\section{GrN-4946. Culemborg 93}

$$
\begin{gathered}
2620 \pm 50 \\
670 \text { B.C. } \\
\delta C^{1 s}=-27.3 \%
\end{gathered}
$$

Charcoal from Pit $6 \mathrm{~B}$ with fragments of human skull. Pit from 1st stage of settlement (Hallstatt D) and intersected by trench forming part of house plan. Depth 0.30 to $0.60 \mathrm{~m}$.

\section{GrN-4945. Culemborg 101}

$$
\begin{array}{r}
2600 \pm 70 \\
650 \text { B.C. } \\
\delta C^{1 s}=-26.7 \% \circ
\end{array}
$$

Charcoal from bottom of settlement pit from 1st stage of habitation. Depth 0.50 to $0.55 \mathrm{~m}$. 


\section{GrN-4947. Culemborg 210-214}

Charcoal from settlement Pit $2 \mathrm{~A}$, from concentration at base and scattered in fill. Pit rich in sherds, including Early La Tène (Marne) types. Depth 0.30 to $0.75 \mathrm{~m}$.

\section{GrN-5001. Culemborg, Post 8}

$$
\begin{gathered}
\mathbf{2 2 1 0} \pm \mathbf{5 0} \\
\mathbf{2 6 0} \text { B.c. } \\
\delta C^{1 s}=-27.2 \%
\end{gathered}
$$

Worked wooden Post 8 (Alnus) in gully deposit, assoc. with iron dagger and potsherds including Early La Tène types. Sample dates last stage of settlement. Depth 0.80 to $1.00 \mathrm{~m}$.

General Comment: dates suggest continuous habitation from ca. 2600 to 2200 B.P.

\section{GrN-4622. Emmererfscheidenveen, $N$ foot path,
Netherlands \\ 530 в.C. \\ $\delta C^{13}=-28.2 \%$}

Outer 10 to 15 tree rings of plank of $\mathrm{N}$ foot path in bog sec. Emmen 15 near Tweede Groene Dijk at Emmererfscheidenveen $\left(52^{\circ} 47^{\prime} \mathrm{N}\right.$ Lat, $6^{\circ} 59^{\prime}$ E Long), Emmen, prov. of Drenthe. Depth 0.40 to $1.30 \mathrm{~m}$. Pollen diagram in van Zeist (1955). Coll. 1963 and subm. by W. A. Casparie, Biol.-Archaeol. Inst., Univ. Groningen, Netherlands. Expected age 0 to 500 в.c. or ca. 1150 B.c. Comment: pretreated with acid and alkali. Sample from same area as GrN-4624 and GrN-4623, Emmererfscheidenveen-Groene Dijk (Bourtanger Moor series, above). Compare dates from $S$ foot path in sec. Emmen 16 in same area GrN-4149: $3120 \pm 50$ and GrN-4342: $3145 \pm 55$ (R., 1967, v. 9, p. 135). See also Casparie (in press).

\section{Coastal dunes series, Netherlands}

Many radiocarbon measurements were made during geologic, palynologic, and archaeologic studies of coastal dunes in $W$ Netherlands (Jelgersma, et al., 1970). Two systems occur: the Older Dunes on a system of parallel coastal barriers in which they originated, and the Younger Dunes, which often reveal several series with parabolic forms. Wet phases, indicated by soil horizons, and dry phases of active dune building alternate synchronously over area. This cyclic development runs parallel to a series of transgressions and regressions. Human occupation was continuous from Late Neolithic Vlaardingen culture up to 12th century A.D. when Upper Dunes made area uninhabitable. No dune formation of any importance occurred from ca. A.D. 1 to 1200. Only dates of Iron age and Roman archaeologic material are listed here. For Neolithic and Bronze age dates, see R., 1963, v. 5, p. 163-202 (Haamstede, the Hague, Vogelenzang), R., 1967, v. 9, p. 107-155 (Voorschoten, Leidschendam, Heemstede), and this list (Leidschendam, Zandwerven, Haarlem). Dates of mainly geologic importance will be included in a future date list. 
GrN-4665. Vogelenzang-AWL XIV/1

Charcoal from occupation soil in Sec. XIV in Amsterdam "Waterleiding” dunes near Vogelenzang (52० $19^{\prime} \mathrm{N}$ Lat, $4^{\circ} 34^{\prime} \mathrm{E}$ Long). Depth 4.00 to $4.30 \mathrm{~m}$ below surface. In overlying sand near its base, a pot of type Ruinen-Wommels I (Zeijen culture) was found, for which date is terminus post quem. Coll. 1963 by J. de Jong, Geol. Dienst, Haarlem. Comment: pretreated with acid only.

\section{GrN-5505. Velzen VIII}

$$
\begin{aligned}
& 2210 \pm 70 \\
& 260 \text { B.C. }
\end{aligned}
$$

Outer tree rings of stump in post hole of 6-post shed in excavated settlement with pottery of Ruinen-Wommels III type (Protofrisian culture) at Dutch Steelworks at Velzen $\left(52^{\circ} 29^{\prime} \mathrm{N}\right.$ Lat, $4^{\circ} 38^{\prime} \mathrm{E}$ Long), prov. of Noord-Holland. Expected age 2300 B.P. Depth 8 m. Coll. 1965 by R. E. Lutter; subm. 1967 by J. F. van Regteren Altena. Comment: pretreated with acid and alkali.

\section{GrN-5485. Velzen IX}

Collagen from human femur in inhumation grave in pit adjacent to shed described above. Depth $8 \mathrm{~m}$. Coll. 1965 by R. E. Lutter; subm. 1967 by J. F. van Regteren Altena. Comment: pretreated as for unburnt bone.

\section{GrN-5195. Velzen II}

Post of Farm House I excavated 1963 at Dutch Steelworks near Velzen $\left(52^{\circ} 29^{\prime} \mathrm{N}\right.$ Lat, $4^{\circ} 38^{\prime} \mathrm{E}$ Long) by J. F. van Regteren, Altena. From ca. 40 tree rings from outside of stem. Depth $6.5 \mathrm{~m}$. House is 2 nd of 3 successive buildings at site. Roman pottery dates 1st stage of settlement to middle of lst century A.D. Coll. and subm. 1966 by excavator. Comment: pretreated with acid only. In comparison with 2 following dates, date appears too old, which may be due to re-use of old wood.

GrN-5196. Velzen III

$2020 \pm 55$

70 B.C.

$\delta C^{13}=-24.9 \%$

Post from same house as GrN-5195, ca. 30 to 35 tree rings from outside of stem. Comment: pretreated with acid only.

\section{GrN-4833. Velzen I}

$$
\begin{array}{r}
\mathbf{1 9 4 0} \pm \mathbf{5 0} \\
\text { A.D. 10 } \\
\delta C^{13}=-23.9 \%
\end{array}
$$

Third post from same house, at ca. 30 to 35 tree rings from outside of stem. Comment: pretreated with acid and alkali. 
General Comment: series includes 1st date in Netherlands for RuinenWommels III stage. For further comments, see Jelgersma et al., 1970.

\section{Paddepoel III series, Netherlands}

Clay covered Iron age settlement (terp mound) No. III in former sea marsh area in new suburb Paddepoel of town of Groningen (53 ${ }^{\circ}$ 13' N Lat, 6 $6^{\circ} 34^{\prime} \mathrm{E}$ Long), prov. of Groningen, excavated 1964 by W. A. van Es, formerly Biol.-Archaeol. Inst., Univ. Groningen; present address Rijksdienst v. het Oudheidkundig Bodemonderzoek, Amersfoort, Netherlands (van Es, 1971). Coll. and subm. by excavator.

\section{GrN-5592. Paddepoel 332}

$$
\begin{gathered}
2125 \pm 35 \\
175 \text { B.c. } \\
\delta C^{13}=-24.0 \%
\end{gathered}
$$

Wood from post in post hole of house, belonging to Stage II of settlement. Depth 1.50 m. Expected age: ca. 100 B.C. to A.D. 100.

\section{GrN-5591. Paddepoel 331}

Wood from post in post hole of granary, belonging to later stage of settlement. Depth $1.00 \mathrm{~m}$. Expected age: ca. A.D. 1 to 200 .

General Comment: both samples pretreated with acid and alkali. Earlier than expected.

\section{Roman and later}

\section{GrN-5491. Lathum, Netherlands}

$$
\begin{aligned}
2000 \pm 65 \\
50 \text { B.C. } \\
\delta C^{13}=-28.8 \%
\end{aligned}
$$

Top of peat layer at 1.06 to $1.08 \mathrm{~m}$ depth below single levee clay deposit of IJssel R. in sec. near Lathum, Angerlo $\left(51^{\circ} 59^{\prime} \mathrm{N}\right.$ Lat, $6^{\circ} 8^{\prime}$ E Long), prov. of Gelderland (Poelman and Harbers, 1966) between Arnhem and Doesburg. Possibility exists that this narrow part of IJssel R. was not original but dug by Romans under Drusus. Coll. 1967 by J. N. B. Poelman; subm. by G. C. Maarleveld, Univ. of Amsterdam. Comment: pretreated with acid and alkali. Date agrees with suggested Roman origin of river section.

\section{Ouddorp series, Netherlands}

Settlement from Roman period at Ouddorp $\left(51^{\circ} 49^{\prime} \mathrm{N}\right.$ Lat, $3^{\circ} 59^{\prime}$ E Long), Goedereede I., prov. of Zeeland, excavated 1959 by J. A. Trimpe Burger, Rijksdienst v. het Oudheidkundig Bodemonderzoek (Trimpe Burger, 1961). Subm. 1966 by excavator.

\section{GrN-4968. Ouddorp I}

$$
\begin{gathered}
\mathbf{1 8 7 0} \pm \mathbf{3 5} \\
\text { A.D. } 80 \\
\delta C^{13}=-22.6 \%
\end{gathered}
$$

Charred grain (Hordeum vulgare) in thick layer in corner of burnt house or shed. Depth $0.50 \mathrm{~m}$. Assoc. with abundant pottery dating from Ca. A.D. 125 to 150 . 


\section{GrN-4969. Ouddorp II}

$$
\begin{gathered}
1970 \pm 40 \\
20 \text { B.c. } \\
\delta C^{1 s}=-25.1 \% o
\end{gathered}
$$

Charcoal from last stage of settlement from layer of Roman roof tiles and burnt wood. Depth $0.50 \mathrm{~m}$. Date of underlying broken pottery supposedly ca. A.D. 200, but a later age (after A.D. 250) considered possible. General Comment: both samples pretreated with acid and alkali. GrN-4968 as expected, but GrN-4969 is 2 or 3 centuries too high, which may be due to re-use of timber and/or to high age of wood when cut.

\section{GrN-4967. Aardenburg, Netherlands}

$1835 \pm 35$

\section{A.D. 115}

$$
\delta C^{13}=-25.3 \%
$$

Charcoal from burnt Roman temple at Quataert near Aardenburg $\left(51^{\circ} 16^{\prime} \mathrm{N} \mathrm{Lat}\right.$, 3 $27^{\prime} \mathrm{E}$ Long), prov. of Zeeland (Trimpe Burger, 1963). Excavated 1962 by J. A. Trimpe Burger. Depth $1.70 \mathrm{~m}$. Coins date temple destruction shortly after A.D. 270 . Subm. 1966 by excavator. Comment: pretreated with acid and alkali. Slightly older than expected, perhaps may be due to age of wood.

\section{GrN-5646. Kapel Avezaath, Netherlands}

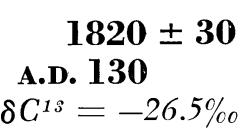

Wood from bottom of $30 \mathrm{~m}$ long supposedly Roman ship from $6 \mathrm{~m}$ depth in former bed of Linge R. at Kapel Avezaath ( $51^{\circ} 52^{\prime} \mathrm{N}$ Lat, $5^{\circ} 23^{\prime}$ E Long), Zoelen, prov. of Gelderland. Small scale rescue excavation 1968 by L. P. Louwe Kooijmans. A few finds in vicinity date from early 3rd century A.D., but of no certain assoc. with ship. Coll. and subm. 1968 by excavator. Comment: pretreated with acid and alkali. Date proves Roman age of ship.

\section{GrN-5382. Bennekom-de Kooi, Netherlands}

$5055 \pm 40$

3105 B.c.

$$
\delta C^{13}=-24.7 \%
$$

Remains of ca. 40 trees found ca. 1930 at depth $0.70 \mathrm{~m}$ in peat near farm de Kooi at Bennekom (52 $0^{\prime} \mathrm{N}$ Lat, $5^{\circ} 41^{\prime} \mathrm{E}$ Long), prov. of Gelderland. Supposedly from a raft of Roman or Carolingian age. Coll. 1966 and subm. 1967 by J. J. Dijkveld Stol, Inst. v. Rassenonderzoek van Landbouwgewassen, Bennekom, Netherlands. Comment: pretreated with acid and alkali. Sample consisted of outer ca. 70 tree rings of trunk. Trees probably buried by natural causes.

\section{Maastricht series, Netherlands}

Fragment of bone (femur) preserved with other human skeletal remains in relic shrine in church of St. Servatius in Maastricht $\left(50^{\circ} 51^{\prime}\right.$ $\mathrm{N}$ Lat, $5^{\circ} 41^{\prime} \mathrm{E}$ Long), prov. of Limburg. Bones traditionally ascribed to St. Martinus of Tongeren, who died some time before A.D. 350 and was closely assoc. with St. Servatius $(+384)$ over whose grave a memorial chapel was built, that later became a famous Romanesque church. 
Shrine manufactured A.D. 1160 and only opened once per century. Coll. and subm. 1963 by dean Msgr. Jennekens.

GrN-4211. Maastricht, St. Martinus, bone collagen

GrN-4212. Maastricht, St. Martinus, bone carbonate
$1530 \pm 50$

A.D. 400

$\delta C^{13}=-19.0 \%$

A.D. 1100

$\mathbf{8 5 0} \pm \mathbf{3 4 0}$

General Comment: pretreated as for unburnt bone, carbonate fraction measured separately. GrN-4212 apparently too young due to exchange with atmospheric $\mathrm{CO}_{2}$. GrN-4211 proves antiquity of bone.

\title{
Paddepoel IV series, Netherlands
}

Early Medieval raised cemetery below terp settlement at Paddepoel IV, $\mathrm{N}$ of Groningen (53 $15^{\prime} \mathrm{N}$ Lat, $6^{\circ} 34^{\prime} \mathrm{E}$ Long), excavated 1964 by W. A. van Es (1971). Top layers of terp were removed before excavation. Subm. by excavator.

\section{GrN-5461. Paddepoel IV-344}

$1415 \pm 30$

A.D. 535

$\delta C^{13}=-25.6 \%$

Charcoal (Quercus) from incomplete cremation of very young child found in circular pit, near inhumation graves. If same age as graves, cemetery would be of mixed type, 7 th to 9 th century A.D. Coll. by W. A. van Es and H. Praamstra.

\section{GrN-5590. Paddepoel IV-298}

\author{
$1205 \pm 45$ \\ A.D. 745 \\ $\delta C^{13}=-27.2 \%$
}

Wood from post in post hole of later building, expected to date from 12th to 13th century A.D. Coll. by W. A. van Es.

General Comment: both samples pretreated with acid and alkali. After correction for de Vries effect, dates are ca. A.D. 600 and A.D. 700 to 870 , respectively. Latter date much older than expected, which may be due to stratigraphic complications, not observed during rescue excavation.

\section{GrN-5489. Stapelen, Netherlands}

$$
\begin{gathered}
\mathbf{1 3 5 0} \pm \mathbf{3 0} \\
\text { A.D. } 600 \\
\delta C^{15}=-25.2 \%
\end{gathered}
$$

Wood from joist, forming part of unique early wooden building incorporated in later stone hall of castle Stapelen $\left(51^{\circ} 35^{\prime} \mathrm{N}\right.$ Lat, $5^{\circ}$ 22' E Long), near Boxtel, prov. of Noord-Brabant. Found during restoration of castle. Sample from outer part of beam. First mention of castle in A.D. 1173. Expected age A.D. 1100-1400. Coll. and subm. 1968 by architect A. van Abeelen, Boxtel, Netherlands. Comment: pretreated with acid and alkali. Much older than expected. 


\section{GrN-4476. Arnhem, Netherlands}

Collagen from human skeleton under foundation of St. Eusebius church at Arnhem (51 $59^{\prime} \mathrm{N}$ Lat, $5^{\circ} 55^{\prime} \mathrm{E}$ Long), prov. of Gelderland, with remains of buildings and sarcophagi made from tuff, and indicating earlier occupation of site than hitherto assumed. Coll. and subm. 1960 by K. Schaap, Town Archivarian, Arnhem, Netherlands. Comment: pretreated as for unburnt bone. Date agrees with main period of use of tuff as building stone in the low countries.

\section{Utrecht series, Netherlands}

Wood from house Drakenburg at Utrecht $\left(52^{\circ} 05^{\prime} \mathrm{N}\right.$ Lat, $5^{\circ} 8^{\prime}$ E Long), prov. of Utrecht. Expected age either 17th century A.D., or Medieval; in latter case very early instance of use of Abies-wood in Netherlands. Coll. 1967 by H. van der Waal, Rijksdienst v. de Monumentenzorg, The Hague; subm. 1968 by J. A. Brongers, Rijksdienst v. het Oudheidkundig Bodemonderzoek, Amersfoort, Netherlands.

\section{GrN-5626. Utrecht 1}

Wood from beam above 1st floor.

\section{GrN-5627. Utrecht 4}

Wood from rafter.

General Comment: both samples pretreated with acid and alkali. Dates prove Medieval age of wood. Comparison with Bristlecone chronology leads to 13th century as probable historical date of use of Abies-wood for building of house.

\section{Dokkum series, Netherlands}

Excavation in 1966 during restoration of St. Boniface church at Dokkum $\left(53^{\circ} 20^{\prime} \mathrm{N}\right.$ Lat, $6^{\circ} 0^{\prime} \mathrm{E}$ Long), prov. of Friesland. On artificial mound, built ca. A.D. 760,2 or 3 wooden churches were built successively, replaced ca. 1050 by tuff stone church (Halbertsma, 1961). Coll. 1966 by W. A. Casparie; subm. by H. Halbertsma, Rijksdienst v. het Oudheidkundig Bodemonderzoek, Amersfoort, Netherlands.

\section{GrN-5157. Dokkum 1966 C}

$1160 \pm \mathbf{3 0}$
A.D. 790
$\delta C^{13}=-25.6 \%$

Outer 20 tree rings of oak coffin, from oldest group of graves dug into mound. Coffin partly destroyed to provide space for poles of wooden church. Depth $2.50 \mathrm{~m}$. 


\title{
GrN-5158. Dokkum 1966 B
}

\author{
$1045 \pm 50$ \\ A.D. 905 \\ $\delta C^{13}=-25.9 \%$
}

Outer 20 to 30 tree rings of post of wooden church. Depth $2.50 \mathrm{~m}$. General Comment: both samples pretreated with acid and alkali. Measurement of other post of wooden church: GrN-4713: $960 \pm 50$ (A.D. 990) (R., 1967, v. 9, p. 138). Correction for de Vries effect would make dates 40 to 100 yr younger. They remain within expected time range.

\section{Rijnsburg series, Netherlands}

Excavations in 1949 and 1951 at Rijnsburg (52 $11^{\prime} \mathrm{N}$ Lat, $4^{\circ} 27^{\prime}$ E Long), prov. of Zuid-Holland, yielded remains of 12th century church and other buildings of Medieval Benedictine abbey of Rijnsburg. In transept of church 8 graves were found, supposedly from members of Holland line of counts, buried in abbey up to A.D. 1299. One countess $($ Ada +1258$)$ historically known to have been buried before high altar. One of skeletons showed sword-inflicted damages, corresponding in detail to description of violent death of Count Floris V in A.D. 1296. Graves and foundation trenches were dug into cultural layers of Carolingian and Merovingian age. Outside church, but within abbey buildings, graves were found supposedly belonging to noble abbesses or possibly young female members of House of Holland. Many graves of latter group were destroyed. For details of excavations see Glasbergen (1950, 1954) and Glasbergen and van Regteren Altena (1964). Anthropologic studies by B. K. S. Dijkstra are in progress. Three measurements by H. de Vries pub. (Science, 1958, v. 128, p. 1555). Samples coll. by W. Glasbergen; subm. by W. Glasbergen and B. K. S. Dijkstra.

\section{GrN-677. Rijnsburg 92}

GrN-680.

Organic matter from bones, probably of Count Floris V (A.D. 1254 to 1296). Two measurements of same sample already pub. (op. cit., above). Mean value: $915 \pm 60$ (A.D. 1035).

\section{GrN-1111. Rijnsburg 93}

Organic matter from bones possibly of Floris, brother of Count Willem I (+ ca. 1210). Date pub. (op. cit., above).

\section{GrN-4235. Rijnsburg $93^{a}$}

$1225 \pm 50$

A.D. 725

$\delta C^{13}=-19.0 \%$

New analysis of same sample as GrN-1111. Comment: pretreated as for unburnt bone (Vogel, unpub.). 


$$
1120 \pm 65
$$

GrN-3040. Rijnsburg $9^{\text {b }}$

A.D. 830

New sample from same skeleton as GrN-1111. Comment: pretreated as Rijnsburg 98, below, and unprecipitable fraction of acid solution measured.

\section{GrN-3026. Rijnsburg 97}

$1100 \pm 25$

Organic matter from bones, possibly of Floris IV (A.D. 1210 to 1234). Comment: pretreated as Rijnsburg $93^{\text {b }}$, above.

\section{GrN-836. Rijnsburg 98, residue}

$$
\begin{array}{r}
1460 \pm 150 \\
\text { A.D. } 490 \\
1050 \pm 50 \\
\text { A.D. } 900 \\
960 \pm 40 \\
\text { A60 } \\
\text { A.D. } 990
\end{array}
$$

GrN-1894. Rijnsburg 98 ${ }^{\mathrm{a}}$, extract a

GrN-1895. Rijnsburg 98 ${ }^{\text {b }}$, extract $b$

Bones, possibly of Ada $(+1258)$. Comment: pretreatment procedure used by de Vries, for this sample as follows: bone dissolved in strong hydrochloric acid, insoluble fraction measured (GrN-836). Organic matter and salts precipitated from acid solution by increasing the $\mathrm{pH}$. Fraction precipitated at $\mathrm{pH} 4$ measured (GrN-1894). Fraction not precipitated at $\mathrm{pH} 8$, dried and measured (GrN-1895). According to de Vries, $\mathrm{pH} 4$ fraction gave best result, i.e., A.D. 900.

GrN-3029. Rijnsburg 102

A.D. 670

$1280 \pm 50$

Organic matter from bones, possibly of Godevaert (ca. A.D. 1190). Comment: pretreated as Rijnsburg $93^{\text {b }}$, above.

\section{GrN-2968. Rijnsburg, ambulatory}

$$
1025 \pm 45
$$

Organic matter from skeleton found in ambulatory, presumably younger than other skeletons. Comment: pretreated as Rijnsburg 93, above.

\section{GrN-4232. Rijnsburg 174}

$$
\begin{aligned}
& \mathbf{8 6 0} \pm \mathbf{5 5} \\
& \text { A.D. } 1090 \\
& \delta C^{13}=-20.2 \%
\end{aligned}
$$

Collagen from skeleton found in ambulatory, possibly of Beatrix, married to Floris V. Comment: pretreated as for unburnt bone (Vogel, unpub.).

\section{GrN-6097. Rijnsburg-Willem I}

$$
1215 \pm 50
$$

\section{A.D. 735}

$\delta C^{13}=-19.9 \%$

Collagen from skeleton, possibly of Count Willem I ( + A.D. 1223). Comment: pretreated as for unburnt bone (Vogel, unpub.).

General Comment: C13/12 correction applied in 3 instances only. Since $\mathrm{C}^{13}$ for human bones is, in general, ca. $-20 \%$, other samples would 
become ca. $80 \mathrm{yr}$ older when corrected. Fluctuation in atmospheric $\mathrm{C}^{14}$ concentration will cause dates to be too old by, at most, $150 \mathrm{yr}$, which is not enough to bridge difference with expected historic ages. Historic data strongly support archaeologic dating of graves. Yet earlier cemetery at site is quite possible in view of local continuity of habitation since 7 th century and probability of earlier church or chapel. No explanation for radiocarbon age discrepancy of 3 centuries or more for most samples. Results are internally consistent and similar results for different methods of pretreatment increase their reliability. Further analyses of well dated bones are needed.

\section{Ginkel series, Netherlands}

Two charcoal samples from sec. in old arable soil (enk) at Ginkel $\left(52^{\circ} 2^{\prime} \mathrm{N}\right.$ Lat, 5० 44' E Long), Ede, prov. of Gelderland. Coll. 1962 by J. C. Pape; subm. 1963 by G. C. Maarleveld.

\section{GrN-5168. Ginkel 1}

$1950 \pm 50$

A.D. 1

$\delta C^{13}=-26.3 \%$

Charcoal from 0.60 to $0.75 \mathrm{~m}$ depth in upper layer of natural soil profile below arable soil. Expected age ca. A.D. 150.

\section{GrN-5167. Ginkel 2}

$$
\begin{array}{r}
2570 \pm 50 \\
\mathbf{6 2 0} \text { B.C. } \\
\delta C^{13}=-27.0 \% \circ
\end{array}
$$

Charcoal from 0.40 to $0.55 \mathrm{~m}$ depth in lower part of arable soil. Expected age ca. A.D. 150.

General Comment: both samples pretreated with acid only. Can only be used as terminus post quem for arable soil. Large difference between dates indicates heterogeneity of charcoal at site. See also dates from Rekken and Eibergen, below.

\section{GrN-5169. Rekken, Netherlands}

$$
\begin{gathered}
\mathbf{1 2 6 5} \pm \mathbf{5 0} \\
\text { A.D. } 685 \\
\delta C^{13}=-26.2 \%
\end{gathered}
$$

Charcoal in upper layer of natural soil profile below arable soil (enk) at Rekken $\left(52^{\circ} 6^{\prime} \mathrm{N}\right.$ Lat, $6^{\circ} 44^{\prime} \mathrm{E}$ Long), prov. of Gelderland. Depth 0.90 to $1.05 \mathrm{~m}$. Expected age ca. A.D. 150. Coll. 1962 by J. C. Pape; subm. by G. C. Maarleveld. Comment: pretreated with acid only. Younger than expected, but still only a terminus post quem for enk.

\section{Eibergen series, Netherlands}

Two charcoal samples from sec. in old arable soil at Beltrum, Eibergen $\left(52^{\circ} 06^{\prime} \mathrm{N}\right.$ Lat, $6^{\circ} 49^{\prime} \mathrm{E}$ Long), prov. of Gelderland (Pape, 1966). Coll. and subm. 1968 by J. C. Pape.

GrN-2940. Eibergen 1

$$
1685 \pm 65
$$

\section{A.D. 265}

Charcoal from upper $0.20 \mathrm{~m}$ of old land surface below arable soil. 
GrN-2943. Eibergen 2

Charcoal from lower $0.20 \mathrm{~m}$ of arable soil.

General Comment: pretreated with acid only. See also dates from Ginkel and Rekken, above.

\section{REFFRENCES}

Alkim, U. B. and Alkim, H., 1966, Excavations at Gedikli (Karahöyük). First preliminary report: Belleten, v. 30 , p. 117.

Allain, J. and Fritsch, R., 1967, Le Badegoulien de l'abri Fritsch aux Roches de Pouligny-St-Pierre (Indre): Soc. Préhist. Française Bull., v. 64, p. 83-94.

Andrist, D. and Flükiger, W., 1962, Das Simmental zur Steinzeit: Bern, Stämplfli.

Bakker, J. A. and Brandt, R. W., 1966, Opgravingen to Hoogkarspel III: WestFrieslands Oud en Nieuw, v. 33, p. 167-228.

Bakker, J. A. and van der Waals, J. D., The last phase of the TRB culture in the Netherlands and West Germany, in: Kjaerum, P. (ed.), Acta 3rd Atlantic Colloquium-Aarhus 1969.

Bakker, J. A., Vogel, J. C., and Wiślanski, T., 1969, TRB and other $\mathrm{C}^{14}$ dates from Poland: Helinium, v. 9, p. 3-27 (A), p. 209-238 (B).

Beex, G. and Hulst, R. S., 1968, A Hilversum-culture settlement near Nijnsel, municipality of St. Oedenrode, North Brabant: Ber. van de Rijksdienst voor het Oudheidkundig Bodemonderzock, v. 18, p. 117-129.

Bender, M. M., 1968, Mass spectrometric studies of carbon 13 variations in corn and other grasses: R., v. 10, p. 468-472.

Berciu, D. 1967, Romania before Burcbista: London, Thames \& Hudson.

Bottema, S., 1967, A Late Quaternary pollen diagram from Ioannina, North-Western Greece. Appendix to F. Higgs and others, The climate, environment and industries of Stone age Greece, Part III: Prehist. Soc. Proc., v. 33, p. 26-29.

Bottema, S. and van Straaten, L., 1966, Malacology and palynology of two cores from the Adriatic sea floor: Mar. Geol., v. 4, p. 553-564.

Brodar, M., 1959, Crvena Stijena, cine neue Paläolithistation aus dem Balkan in Jugoslawien: Quartär, v. $10 / 11(1958 / 59)$, p. 213-236.

du Burck, P. and Dekker, L. W., 1968, Enkele resultaten van het onderzoek naar de genese van de gronden in midden-Westfriesland: Boor en Spade, v. 16, p. 131-156.

Burger, D., 1964, Results of a pollenanalytical investigation in the Untersee near Lunz in Austria: Geol. Mijnbouw, v. 43, p. 94-102.

Butler, J. J., 1969, Nederland in de bronstijd. Bussum, Fibula-van Bishoeck.

Butter, J., 1957, Vondsten in het oerstroomdal van de Overijsselse Vecht: Koninkl. Nederl. Aardrijkskundig Genootschap, v. 74, p. 239-241.

Casparie, W. A., 1969, Bult- und Schlenkenbildung in Hochmoortorf: Vegetatio, v. 19 , p. $146-180$. Bog development in Southeastern Drenthe (the Netherlands): Doctoral

thesis, Groningen, in press.
Chiapella, V. G., 1958, Scavi nella grotta del Colombo (Toirano): Riv. di St. Lig., v. 24 , p. $98-105$.

Craig, Harmon, 1954, Carbon 13 in plants and the relationships between carbon 13 and carbon 14 variations in nature: Jour. Geology, v. 62, p. 115-149.

Crandell, D. R., Mullineaux, D. R., and Waldron, H. H., 1958, Pleistocene sequence in the south-eastern part of Puget Sound Lowland, Washington: Am. Jour. Sci., v. 256 , p. $384-397$.

Donner, J. J., 1969, Holocene pollen diagrams from the Beune valley, Dordogne: Pollen et Spores, v. 11, p. 97-116.

Dreimanis, A., Terasmae, J., and McKenzic, G. D., 1966, The Port Talbot Interstade of the Wisconsin Glaciation: Canadian Jour. of Earth Sci., v. 3, p. 305-325.

Dreimanis, A. and Vogel, J. C., 1965, Reevaluation of the length of the Port Talbot Interstadial in the Lake Erie region, Canada: Radiocarbon and Tritium dating, 6th intern. ${ }^{14} \mathrm{C}$ and tritium dating conf. 17.E.C. Proc., p. 720-729.

Dumitrescu, V., 1963, Originea si evolutia culturii Cucuteni-Tripolje: Studii si cercetări de istorie veche, v. 14, p. 51-78, 285-308.

Dunand, M., 1961, Rapport préliminaire sur les fouilles de Byblos en 1957, 1958, 1959: Mus. de Beyrouth Bull., v. 16, p. 69-85.

Easterbrook, 1969, Pleistocene chronology of the Puget Lowland and San Juan Islands, Washington: Geol. Soc. America Bull., v. 80, p. 2273-2286. 
Easterbrook, D. J., Crandell, D. R. and Leopold, E. B., 1967, Pre-Olympia Pleistocene stratigraphy and chronology in the Central Puget Lowland, Washington: Geol. Soc. America Bull., v. 78, p. 13-20.

van Es, W. A., 1971, Paddepoel, excavations of frustrated terps, 200в.c.-250A.D.: Palacohistoria, v. 14

van Es, W. A. and Casparie, W. A., 1968, Mesolithic wooden statuette from the Volkerak, near Willemstad, North Brabant: Ber. van de Rijksdienst voor het Oudheidkundig Bodemonderzoek, v. 18, p. 111-118.

Ferrians, O. J., 1963, Glaciolacustrine diamicton deposits in the Copper River Basin, Alaska: U.S. Geol. Survey Prof. Paper 475-c, Art. 91, p. c120-c125.

Franken, H. J., 1969, Excavations at tell Deir 'Allā, I: Leiden, Brill.

Gabalówna, L., 1968, Sprawozdania $z$ prac wykopaliskowych $w$ Sarnowie, pow. Wloclawek, przeprowadzonych w roku 1967 na stanowiskach 1 (English summary): Prace i Materialy, v. 15, p. 135-147.

1969, Badania nad kultura pucharów lejkowatych w Sarnowie: SprawozDeutiske, p. 57-75. Giffen, A. E., 1962, Grafheuvels uit de Midden-Bronstijd met neder-zettingssporen van de Klokbeker-cultuur bij Ooostwoud: West-Frieslands Oud en Nieuw, v. 29, p. $199-209$.

Glasbergen, W., 1950, De Abdijkerk van Rijnsburg; opgravingen in 1949: Jaarb. voor Gesch. en Oudheidkunde van Leiden e.o., p. 89-106.

1954, De Abdijkerk van Rijnsburg; opgravingen in 1951: Jaarb. voor Gesch. en Oudheindkunde van Leiden e.o., p. 46-49.

Glasbergen, W., Groenman-van Waateringe, W., and Hardenberg-Mulder, G. M., 1967, Settlements of the Vlaardingen culture at Voorschoten and Leidschendam: Helinium, v. 7, p. 3-31, 97-120.

Glasbergen, W. and van Regteren Altena, H. H., 1965, De Abdij van Rijnsburg; opgravingen in 1960/61 en 1963/64: Jaarb. voor Gesch. en Oudheidkunde van Leiden e.o., p. 144-157.

Goldthwait, R. P., 1958, Wisconsin age forests in Western Ohio. I. Age and glacial events: Ohio Jour. of Sci., v. 58, p. 209-219

Gooding, A. M., 1963, Illinoian and Wisconsin glaciations in the Whitewater Basin, southeastern Indiana, and adjacent areas: Jour. Geology., v. 71, no. 6, p. 665-682

Halbertsma, H., 1961, Bonifatius' levenseinde in het licht der opgravingen: Ber. van de Rijksdienst voor het Oudheidkundig Bodemonderzoek, v. 10-11 (1960-61), p. $395-444$.

van der Hammen, T., Maarleveld, G. C., Vogel, J. C., and Zagwijn, W. H., 1967, Stratigraphy, climatic succession and radiocarbon dating of the Last Glacial in the Netherlands: Geol. Mijnbour, v. 46, p. 79-95.

van der Hammen, T., Wijmstra, T. A., and van der Molen, H., 1965, Palynological study of a very thick peat section in Greece, and the Würmglacial vegetation in the Mediterranean region: Geol. Mijnbouw, v. 44, p. 37-39.

Hamming, C., Knibbe, M., and Maarleveld, G. C., 1965, Afzettingen van de IJssel, nabij Zwolle: Boor en Spade, v. 14, p. 88-103.

Hartman, A. A., 1968, A study on pollen dispersal and sedimentation in the western part of the Netherlands: Acta Bot. Neerlandica, v. 17, p. 506-549.

Hayen, H., 1963, Grosse Bohlenwege in Randmoor westlich der Unterweser: Praeh. Zeitschr., v. 41, p. 206-209.

1965, Menschenförmige Holzfiguren neben dem Bohlenweg XLII (Ip) im Wittemoor (Gem. Berne, Landkreis Wesermarsch): Oldenburger Jahrb., v. 64, p. $1-25$.

van der Heide, G. D., 1966, Enkele aantekeningen betreffende prehistorische bewoning van het oostelijk deel van het Zuiderzeegebied: Kamper Almenak, p. 200-214.

Hermann, M., Jánnossy, D., Stiéiér, J., and Vértes, L., 1956, Ausgrabungen in der Petényi und Peskö-Höle: Folia Archaeol., Budapest, v. 8, p. 3-22.

Jelgersma, S., de Jong, W., Zagwijn, W. H., and van Regteren Altena, J. F., 1970, The coastal dunes of the Western Netherlands; geology, vegetational history and archeology: Mededel. van de Rijks Geol. Dienst, n.s., v. 21, p. 93-167.

John, B. S., 1965, A possible main Würm Glaciation in West Pembrokeshire: Nature, v. 207, p. $622-623$.

Kirkbride, D., 1966a, Beidha, an Early Neolithic village in Jordan: Archaeology, v. 19 , p. $199-207$ 
1966b, Five seasons at the Pre-Pottery Neolithic village of Beidha in Jordan: Palestine Exploration Quart., v. 98, p. 9-72.

Klimaszewski, M., 1958, Pleistocene outcrop at Dobra near Limanowa, Carpathian Mts.: Acad. Pol. Sci. Bull., sér. sci. chim., géol. et géog., v. 5, p. 341-344.

Korpela, K., 1969, Die Weichsel-Eiszeit und ihr Interstadial in Perapohjola (nördliches Nordfinnland) im Licht von submoränen Sedimenten: Acad. Sci. Fennicae Annales, ser. A. III, v. 99, Helsinki.

Kwaad, F. J. P. M., 1961, Een onderzoek naar de morfogenese van midden WestFriesland: West Frieslands Oud en Nieuw, v. 28, p. 6-44.

Kwaad, F. J. P. M., Riezebos, P. A., and Slotboom, R. T., 1965, Een bijdrage tot de datering van het oppervlakteveen in Noord-Holland: West-Frieslands Oud en Nieuw, v. 32, p. 144-152.

Lasalle, P., 1966, Late Quaternary vegetation and glacial history in the St. Lawrence Lowlands, Canada: Leidse Geol. Med., v. 38, p. 91-128 (pub. separately 1/6/1966).

Lehmann, L. Th., 1965, Placing the pot beaker: Helinium, v. 5, p. 3-31.

Leonardi, P. and Broglio, A., 1962, Le Paléolithique de la Vénétie: Annali Univ. Ferrara, n.s., ser. 15, v. 1 .

Leroi-Gourhan, A. and Brezillon, M., 1966, L'habitation Magdalénienne no. 1, de Pincevent près Montereau (Seine et Marne): Gallia Préhist., v. 9, p. 263-385.

Malez, M., 1962, Romualdo Cave - a new significant Pleistocene site in Istria: Sci. Yugoslavia Bull. A, v. 7, p. 159-160. 1964, Sandalja bei Pula_ein neuer und wichtiger paläolithischer Fundort in Istrien: Sci. Yugoslavia Bull. A, v. 9, p. 154-155.

1965. Pecina Veternica u Medvednici: Acta Geol., v. 5, p. 175-237.

Malez, M. and Vogel, J. C., 1969, Resultati odreotivanja apsolute starosti pleistocenskih naslaga Sandalje II kod Pule u Istri: Geol. Vjesnik, v. 22, p. 11-16.

1970, Die Ergebnisse der Radio-Karbonanalysen der quartären Schichten der Velika Pecina in Nordwest-Kroatien: Sci. Yugoslavia Bull. A, v. 15, p. 390-391.

Menendez Amor, J., 1964, Estudio palinológico de la turbera del Estany (Olot, Gerona): Geol. Mijnbouw, v. 43, p. 118-122.

Menéndez Amor, J. and Florschütz, F., 1962, Un aspect de la végétation en Espagne méridionale durant la dernière glaciation et l'Holocène: Geol. Mijnbouw, v. 41, p. 131-134.

p. 131-134. 1964, Results of the preliminary palynological investigation of samples from a $50 \mathrm{~m}$ boring in Southern Spain: R. Soc. Española Hist. Nat. (Geol.) Bol., v. 62 , p. 251-255.

Muller, E. H., 1964, Quaternary section at Otto, New York: Am. Jour. Sci., v. 262, p. $461-478$.

Munaut, A. V. and Casparie, W. A., Etude dendrochronologique des Pinus sylvestris L. subfossiles provenant de la tourbière d'Emmen (Drenthe, Pays-Bas): Rev. Paleobot, Palynol., in press.

Münnich, K. O. and Vogel, J. C., 1958, Durch Atomexplosionen erzeugter Radiokohlenstoff in der Atmosphäre: Naturwissenschaften, v. 14, p. 327-329. 1959, Alterbestimmung von Süsswasser-Kalkablagerungen: Naturwissenschaften, v. 46, p. 168.

Mycielska-Dowgiallo, E., 1967, Formy szczelinowe i inwolucyjne w piaskach i zwirach doliny Wisty Kolo Tarnobrzega: Peryglacjalny, Biul., v. 16, p. 203-215.

Negahban, E. O., 1970, Excavation of Marlik, in: Actes du VIe cong. internat. des sci. préhist. et protohist., Prague 21-27 août 1966: Prague, Academia, p. 220-222.

van Noten, F., 1967, Een Tjongervindplaats te Meer: Archaeol. Belgica (Brussels), v. 98 , p. $5-25$.

O'Kelly, M. J., 1964, Newgrange interim report: Antiquity, v. 38, p. 288. 1968, Excavations at Newgrange, Co. Meath: Antiquity, v. 42, p. 40-42.

Olson, E. A. and Broecker, W. S., 1959, Lamont natural radiocarbon measurements V: Radiocarbon, v. 1, p. 1-28.

Osole, F., 1963, Klajši paleolitik iz Ovcje Jame: Archeol. vestnik, v. 13/14, p. 129-143.

Pales, L., 1960, Les Empreintes de pied humains de la "Grotta della Basura": Riv. di Studi Liguri, v. 26, p. 25-90.

Pape, J. C., 1966, Enige gegevens over oude bouwlanden: Boor en Spade, v. 15, p. 86-93.

Passek, T. S., 1961, Rannezemledelcheskie (tripolskie) plemena Podnestrovja: Materialy i Issledovanija po Arkheol. SSR, v. 84, p. 105.

Perrot, J., 1968, La préhistoire palestinienne: Supp. au dictionnaire de la Bible, v. 8, p. 286-446. 
Poelman, J. N. B. and Harbers, P., 1966, Heeft Lathum altijd aan de rechter IJsseloever gelegen?: Boor en Spade, v. 15, p. 128-130.

Pokrowska, E. F. and Petrowska, E. A., 1962.

Pons, L. J. and Wiggers, A. J., 1960, De Holocene wordingsgeschiedenis van NoordHolland en het Zuiderzeegebied: Koninkl. Ned. Aardrijkskundig Genootschap Tijdschr., v. 76 (1959), p. 104-152; v. 77 (1960), p. 3-57.

van Regteren Altena, J. F., et al., 1963, The Vlaardingen culture: Helinium, v. 2 (1962), p. 3-35, 97-103, 215-243; v. 3 (1963), p. 39-54, 97-120.

Ross Holloway, R., 1967, Excavations at Satrianum 1966: Am. Jour. Archaeol., v. 71, p. 59-62.

Rust, A., 1950, Die Höhlenfunde von Jabrud (Syrien): Neumünster, Wachholz.

Schubart, H., 1965, Neue Radiokarbon-Daten zur Vor- und Frühgeschichte der iberischen Halbinsel: Madrider Mitt., v. 6, p. 11-19.

Sercelj, A., 1966, Pelodne analize pleistocenskih in holocenskih sedimentov Ljubljanskega Barja: Razprave, p. 431-472.

Smirnova, G. I., 1957, Poeleni pozdnebronzowogo weka i rannego zjeleza wozle $\mathrm{S}$. Magala: Kratkie Soobshchenija Inst. Ark. Akad, Nauk SSR, v. 70, $105 \mathrm{ff}$.

Stekelis, M. and Bar-Yoseph, O., 1965, Un habitat du Paléolithique supérieur à Ein Gev, Israel: L'Anthropologie, v. 69, p. 176-183.

Suess, H., 1970, Bristlecone pine calibration of the radiocarbon time scale. 5200 B.c. to the present, in: Olsson, I. U. (ed.), Radiocarbon variations and absolute chronology, 12th Nobel Symposium Proc., Stockholm, Almquist and Wiksell,
p. 303-311.

Sulimirski, T., 1968, Corded ware and globular amphorae North-East of the Carpathians: London, Athlone. Swiesznikow, I. K., 1967, Kultura Komarowska (French summary): Archeol. Polski,
v. 12, p. 39-107.

Terasmae, Jaan, 1958, Contributions to Canadian palynology-Pt. 2, Non-glacial deposits in the St. Lawrence Lowlands, Quebec; Pt. 3, Non-glacial deposits along Missinaibi river, Ontario: Geol. Survey Canada Bull. 46, p. 13-35.

1960, Contributions to Canadian palynology, No. 2-Pt. 1, A palynological study of postglacial deposits in the St. Lawrence Lowlands [Quebec]: Geol. Survey
Canada Bull. 56, p. 1-22.

Terasmae, J. and Hughes, O. L., 1960a, A palynological and geological study of Pleistocene deposits in the James Bay Lowlands, Ontario: Geol. Survey Canada Bull. 62, 15 pp.

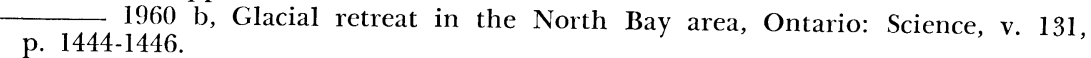

Trimpe Burger, J. A., 1961, Beknopt overzicht van het oudheidkundig bodemonderzoek in het Deltagebied: Ber. van de Rijksdienst voor het Oudheidkundig Bodemonderzoek, v. 10-11 (1960-61), p. 195-209.

voor het Oudheidkundig Bodemonderzoek, van Aardenburg: Ber. van de Rijksdienst voor het Oudheidkundig Bodemonderzoek, v. 12-13 (1962-63), p. 495-548.

Troels-Smith, J., 1960, The Muldbjerg dwelling place; an Early Neolithic archeological site in the Aamosen bog, West-Zealand, Denmark: Smithsonian Inst., rept. for
1959 , p. 577-601.

Valoch, K., 1967, Paleolitické odídlení jeskyné Kulny u Sloupu v Moravském krasu: Archeol. rozhledy, v. 19, p. 566-575.

Valoch, K., Pelíšek, J., Musil, R., Kovanda, J., and Opravil, E., 1969, Die Erforschung der Kulna-Höhle bei Sloup im Mährischen Karst (Tschechoslovakei): Quartär, v.
20, p. 1-45.

Verger, F. and Florschütz, F., 1960, Sur l'existence à Fromentine (Vendée) d'une couche de tourbe du début de l'Atlantique: Acad. sci. [Paris] Comptes rendus,
v. 251, p. 891-893.

Vértes, L., 1955a, Neuere Ausgrabungen und paläolithische Funde in der Höhle von Istállóskö: Acta. Archaeol. Hung., v. 5, p. 111-131.

Acta Archaeol. Hung. valiolithische Kulturen des Würm I/II-Interstadials in Ungarn: Acta Archaeol. Hung., v. 5, p. 261-277. Budapest.

Villaret, P. and Burri, M., 1965, Les découvertes palynologiques de Vidy et signification pour l'histoire du Lac Léman: Soc. Vaud. sci. nat. Bull., v. 69, p. 1-19.

Vogel, J. C., 1969a, Remarks on the $C^{14}$ method: Helinium, v. 9, p. 19-27. 
$83-87$. 1969b, The radiocarbon time-scale: S. African Archacol. Bull., v. 24, p.

1970, $\mathrm{C}^{14}$ trends before 6000 B.P., in: Olsson, I. U. (ed.), Radiocarbon variations and absolute chronology, 12th Nobel Symposium Proc. Stockholm, Almquist \& Wiksell, p. 313-325.

Vogel, J. C., Casparie, W. A. and Munaut, A. V., 1969, Carbon-14 trends in subfossil pine stubs: Science, v. 166, p. 1143-1145.

Vogel, J. C. and Lerman, J. C., 1969, Groningen radiocarbon dates VIII: Radiocarbon, v. 11, p. 351-390.

Vogel, J. C. and Waterbolk, H. T., 1963, Groningen radiocarbon dates IV: Radiocarbon, v. 5, p. 163-202.

1964, Groningen radiocarbon dates V: Radiocarbon, v. 6, p. 349-369.

1967, Groningen radiocarbon dates VII: Radiocarbon, v. 9, p. 107-155.

Vogel, J. C. and Zagwijn, W. H., 1967, Groningen radiocarbon dates VI: Radiocarbon, v. 9, p. 63-106.

de Vries, Hessel, 1959, Variation in concentration of radiocarbon with time and location on earth, in: Abelson, P. H. (ed.), Researches in geochemistry, New York, Wiley \& Sons, p. 180-189.

de Vries, H. and Barendsen, G. W., 1954, Measurements of age by the Carbon-14 technique: Nature, v. 174, p. 1138-1141.

de Vries, H., Barendsen, G. W., and Waterbolk, H. T., 1958, Groningen radiocarbon dates II: Science, v. 127, p. 129-137.

de Vries, H. and Dreimanis, A., 1960, Finite radiocarbon dates of the Port Talbot interstadial deposits in Seuthern Ontario: Science, v. 131, p. 1738-1739.

de Vries, H. and Waterbolk, H. T., 1958, Groningen radiocarbon dates III: Science, v. 128 , p. $1550-1556$.

van der Waals, J. D., 1964, Neolithic disc wheels in the Netherlands: Palaeohistoria,

v. 10, p. 103-147. Netherlands, in: Schwabedissen, H. (ed.), Die Anfänge des Neolithikums vom Orient bis Nordeuropa, Köln, Böhlau, in press.

Waterbolk, H. T., 1962, Hauptzüge der eisenzeitlichen Besiedlung der nördlichen Niederlande: Offa, v. 19, p. 9-46. 1964, The Bronze Age settlement of Elp: Helinium, v. 4, p. 97-131. Working with radiocarbon dates: Prehist. Cong. Proc., Beogard 1971, ms.

in preparation.
Waterbolk, H. T. and van Zeist, W., 1967, Preliminary report on the Neolithic bog settlement of Niederwil: Palaeohistoria, v. 12, p. 559-580.

Watson, P. J., 1965, The chronology of North Syria and North Mesopotamia from 10,000 B.c. to 2000 B.c., in: Ehrich, R. W. (ed.) Chronologies in old world archaeology, Chicago/London, Univ. Press, p. 61-100.

White, G. W. and Totten, S. M., 1965, Wisconsin age of Titusville Till (formerly called “Inner Illinoian") Northwestern Pennsylvania: Science, v. 148, p. 234-235.

Wijmstra, T. A., 1969, Palynology of the first 30 metres of a $120 \mathrm{~m}$ deep section in Northern Greece: Acta bot. Neerlandica, v. 18, p. 511-527.

Wiślanski, T. (ed.), 1970, The Neolithic in Poland: Wroclaw/Warszawa/Kraków,

van Zeist, W., 1955, Pollen analytical investigations in the Northern Netherlands: Doctoral thesis, Groningen.

1967, Palynologisch onderzoek van een ringwalheuvel bij Eersel: Ber. van de Rijksdienst voor het Oudheidkundig Bodemonderzoek, v. 17, p. 53-58.

1971, Prehistoric and Early Historic food plants in the Netherlands: Palaeohistoria, v. 14.

van Zeist, W., Timmers, Ria W., and Bottema, S., 1971, Studies of modern and Holocene pollen precipitation in Southeastern Turkey: Palaeohistoria, v. 14.

Zimmermann, W. H., 1966, Urgeschichtliche Siedlungsreste in Rosdorf, Kreis Göttingen. I. Siedlungsspuren der Bandkeramik, der Bronzezeit und der jüngeren vorrömischen Eisenzeit: Neue Ausgrabungen und Forschungen in Niedersachsen,

v. 3, p. 20-48.
Zotz, L. F., 1955, Das Paläolithicum der Weinberberghöhlen bei Mauern: Bonn, Röhrscheid. 